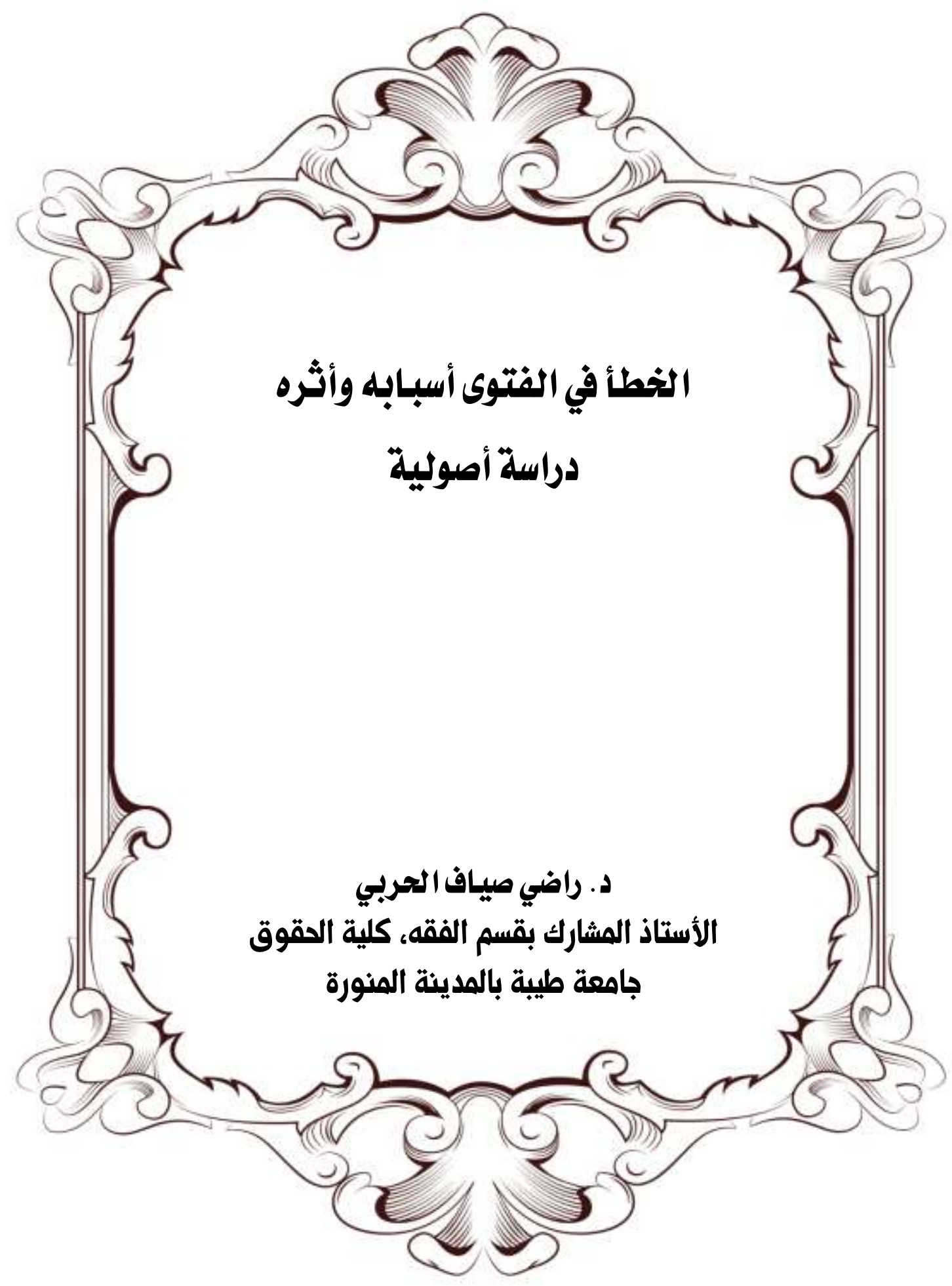


مجلة كلية الدراسات الإسلامية والعربية للبنات بدمنهور العدد الخامس الجزء التاسع •r.rم

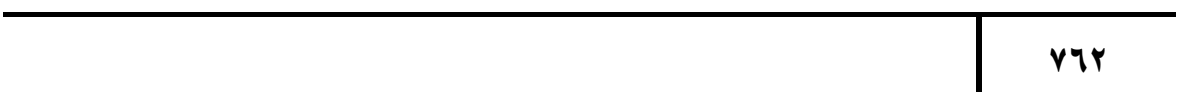


الخطأ في الفتوى أسبابه وأثره دراسة أصولية

$$
\text { راضي صياف الحربي }
$$

قسم الفقه، كلية الحقوق جامعة طيبة بالمدينة المنورة

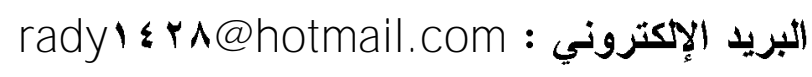

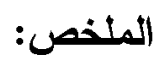

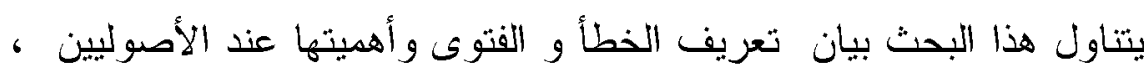

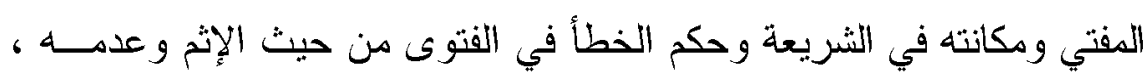

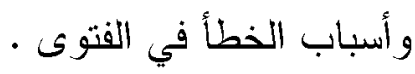

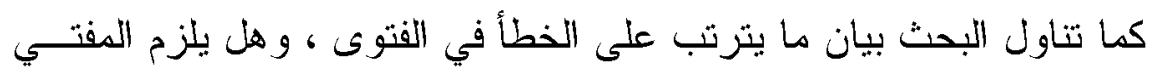

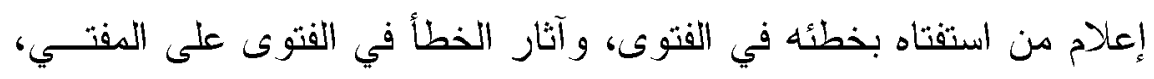
وضمان ما يتلف بناء على الخطأ في الفتوى. الكلمات المفتاحية : الفتوى -المفتي -الخطأ في الفتوى - الكستفتي - آثار الخطأ - ضمان الخطأ 
مجلة كلية الدراسات الإسلامية والعربية للبنات بدمنهور العدد الخامس الجزء التاسع •r+rم

The error in the fatwa, its causes and impact, is a

Rady Sayyaf Al-Harbi

\section{fundamentalist study}

Jurisprudence Department, Faculty of Law, Taibah

University, Madinah

Email : rady\\{r^@hotmail.com

\section{Abstract:}

This research deals with an explanation of the definition of mistake and fatwa and its importance for the fundamentalists, the mufti and his position in Sharia, the ruling on the mistake in the fatwa in terms of sin and lack thereof, and the causes of mistake in the fatwa.

The study also dealt with an explanation of the consequences of a mistake in the fatwa, and whether the mufti is required to inform the questioner of his mistake in the fatwa, the effects of the mistake in the fatwa on the mufti, and assures that what is destroyed based on the mistake in the fatwa.

Praise be to Allah, Lord of the worlds, and peace and blessings of Allah be upon our Prophet Muhammad and his family and companions.

Keywords : Fatwa - The Mufti - Mistake in the Fatwa The Questioner - Effects of Error Guarantee of mistake 


\section{المقدمة}

الحمد لله رب العالمين و الصلاة والسلام على المبعوث رحمة للعـالمين،

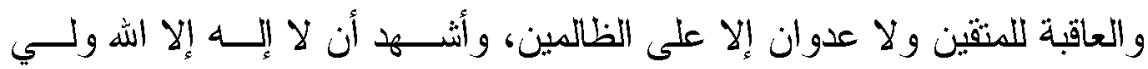

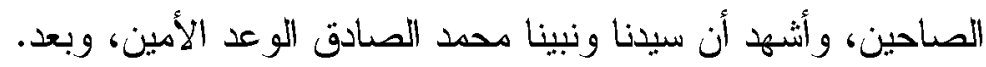

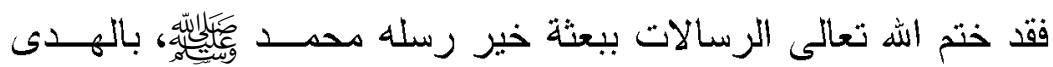

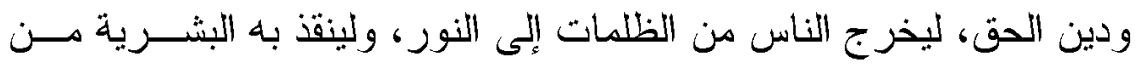

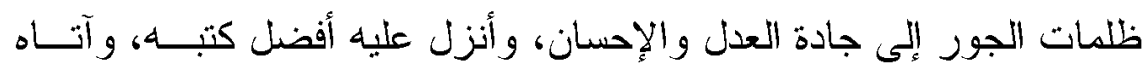

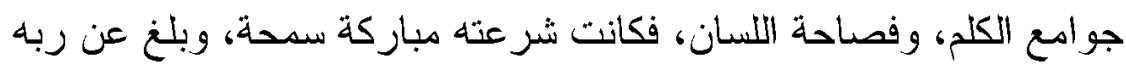

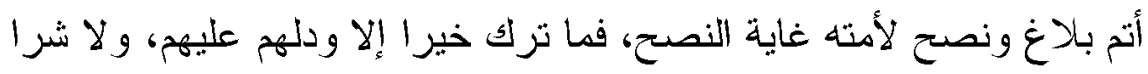

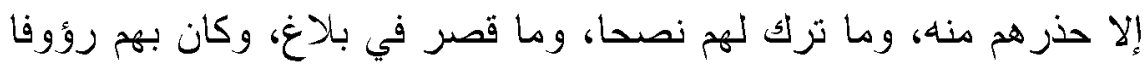
رحيما.

واختار الله له أصحابا على دثال صالح لصحبته، فكانو ا بحـق أئـــة

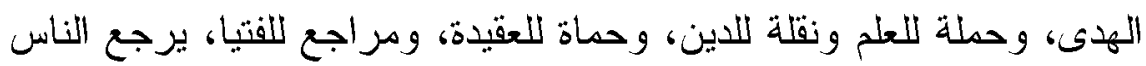

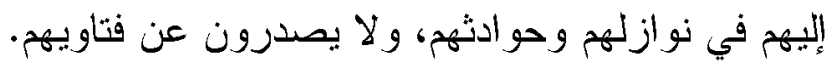

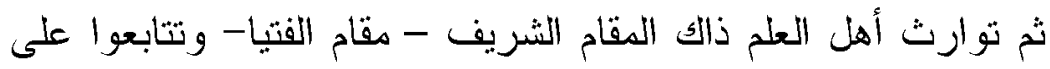

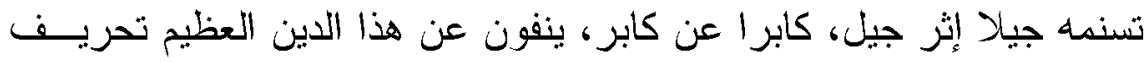

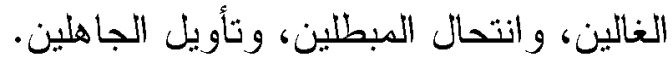

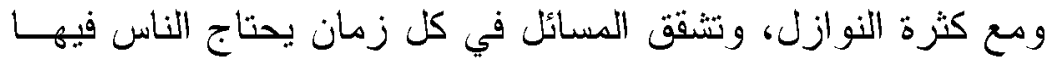

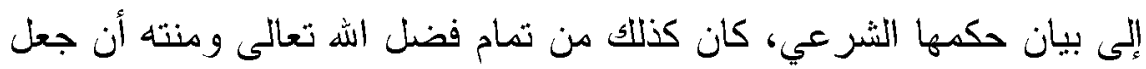

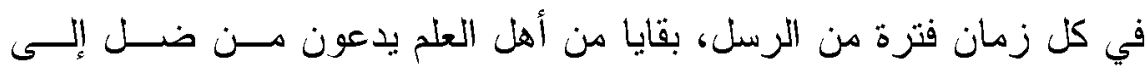

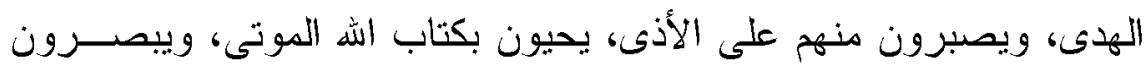

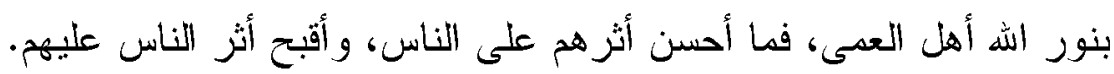

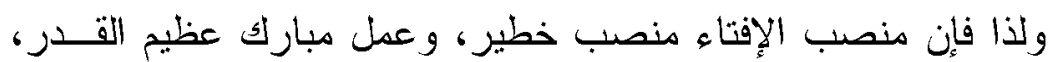

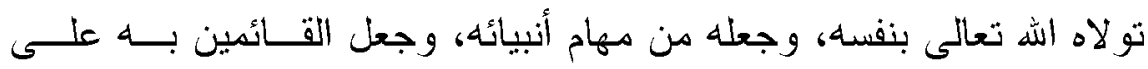

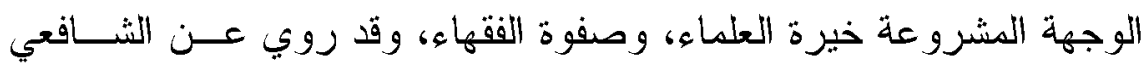


مجلة كلية الدراسات الإسلامية والعربية للبنات بدمنهور العدد الخامس الجزء التاسع •r+rم

رحمه الله تعالى: 》إن لم يكن الفقهاء أولياء الله، فليس لله ولي"(').

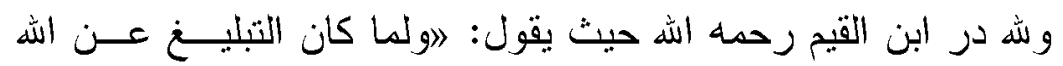
سبحانه يعتمد العلم بما يبلغ، والصدق فيه، لم تصلح مرتبة التبليغ بالرو ايـــة

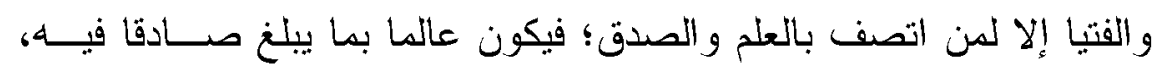
ويكون دع ذلك حسن الطريقة، مرضي السيّرة، عدلاً في أقو الــهـ و أفعالــهـ، دنشابه السر والعلانية في مدخله و مخرجه و أحو اله؛ و إذا كان منصب التوفيع

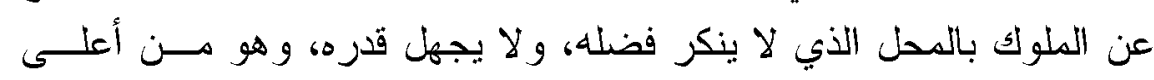

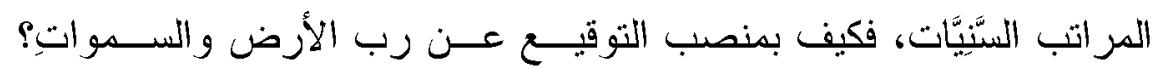
فحقيق بمن أقيم في هذا المنصب أن يعد له عدته، وأن يتأهب له أهبته، وأن

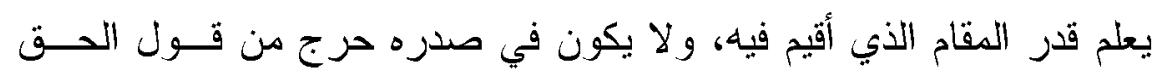
و الصدع بـ؛ فإن الله ناصره و هاديه، وكيف وهو المنصب الذي تو لاه بنفسه

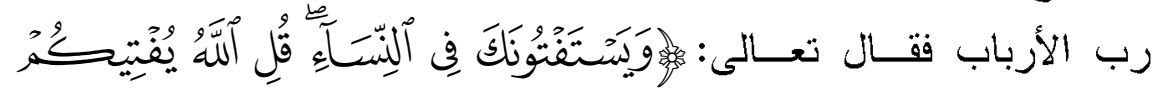

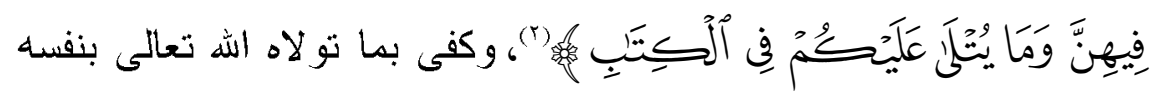

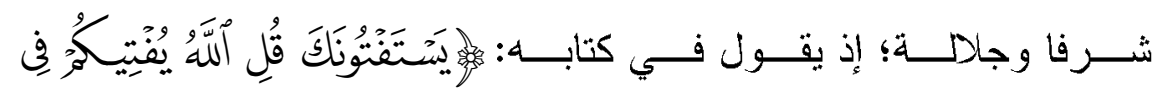

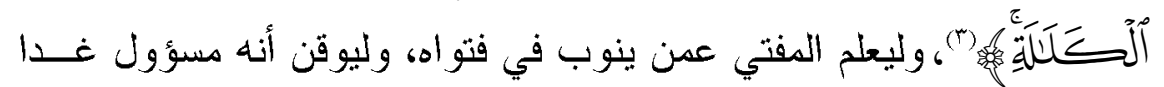
وموقوف بين يدي اللهی(؛).

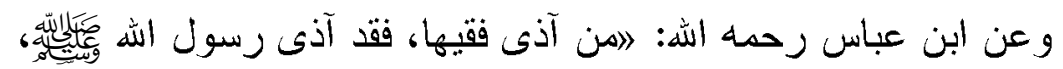

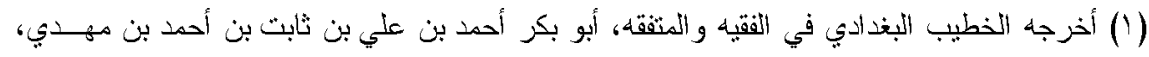

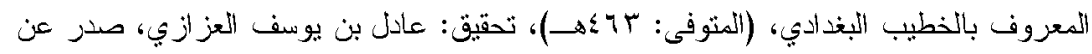

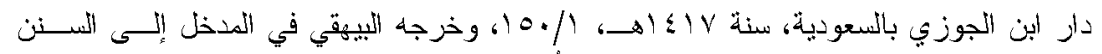

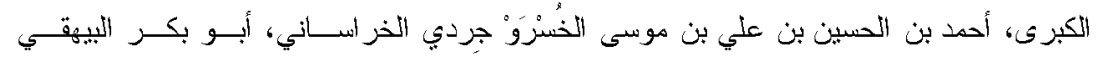

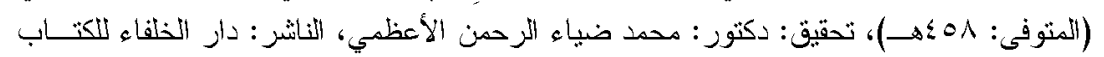

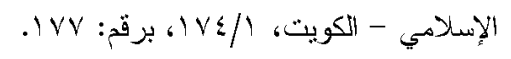

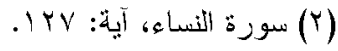

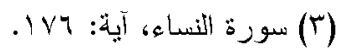

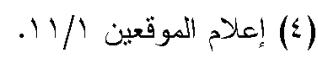




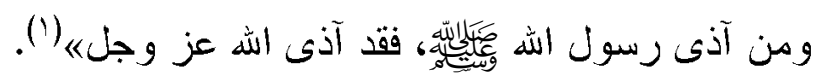

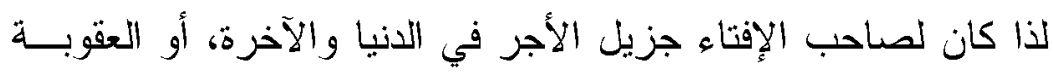

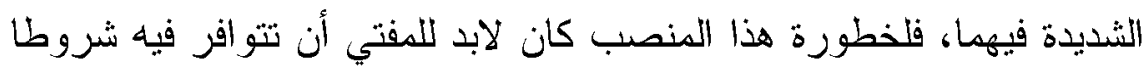

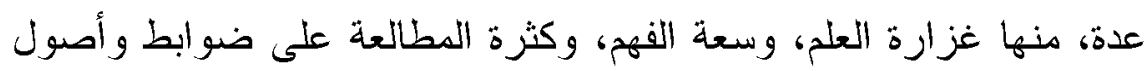
وقو اعد العلم الشرع؛ تجنبا من الوقوع في الغلط، أو الخطأ في الفتيا.

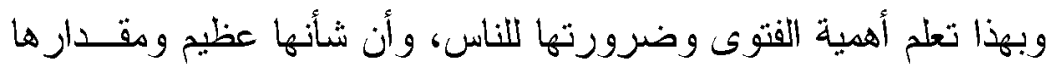

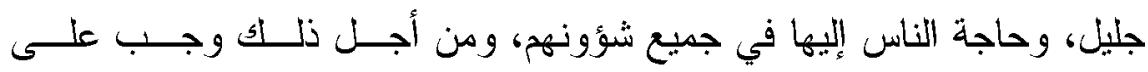

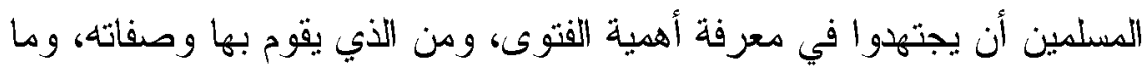

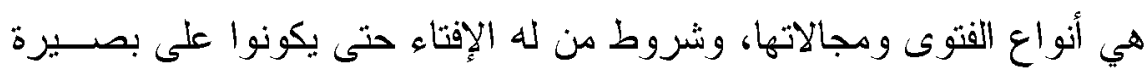

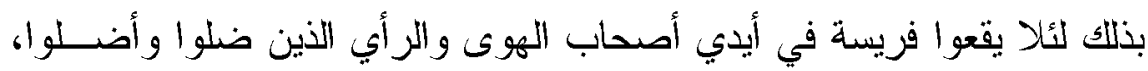

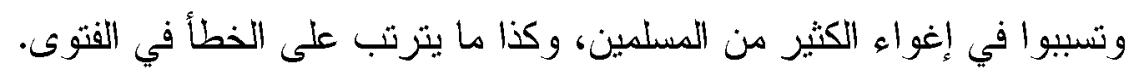


ودن هنا كانت أهمية هذا البحث والذي جاء عنو انه: 》الخطأ في الفتوى

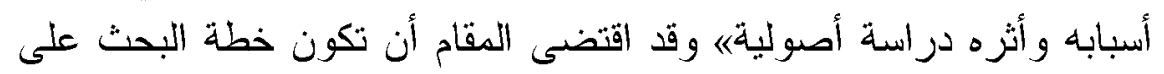
النحو الآتي: المقدمة المبحث الأول: التعريف بمصطلحات البحث، ويشتمل على ثلاثة دطالب:

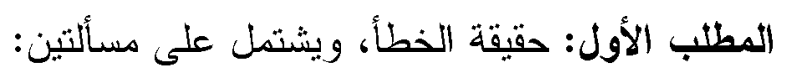

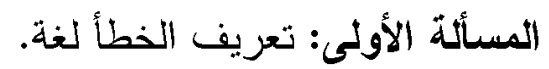

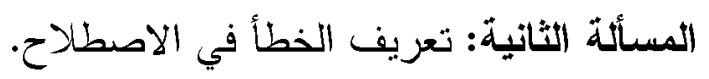
المطلب الثاني: حقيقة الفتوى، وأهميتها، ويشتمل على الألى مسألتين:

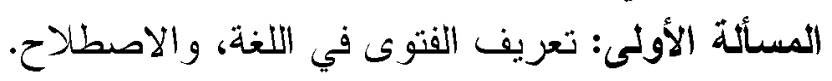

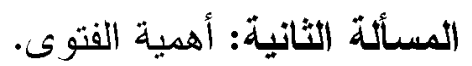
المطلب الثالث: حقيقة المفتي ومكانته في الثريعة، وفيه الفيه أربع دسائل:

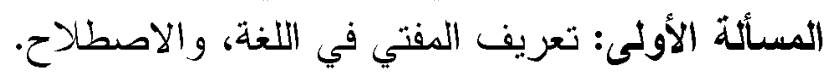

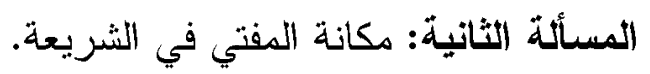

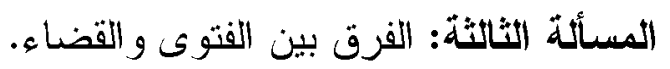
المسألة الرابعة: شروط المفتة المرفي. المبحث الثاني: حكم الخطأ في الفتوى من حيث الإثم و وعدمه. المبحث الثالث: أسباب الخطأ في الفتوى.

المبحث الرابع: ما يترتب على الخطأ في الفتوى، ويشتمل على الفي مطلبين:

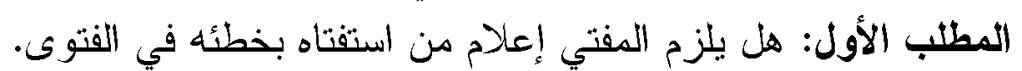

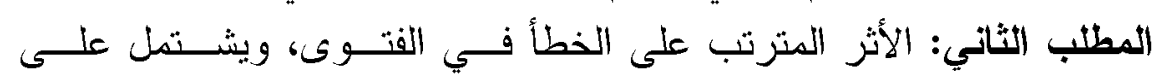
مسألتين:

المسألة الأولى: آثار الخطأ في الفتوى على المفتي.

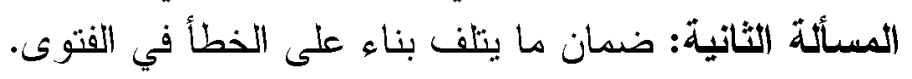
الخاتمة. مصادر البحث. فهرس الموضوعات. 
على أني لم أقف على مؤلف مستقل لتأصيل هذه المسألة، و إنما كانــت مبثوثة في أجزاء دتفرقة دن كتب الأصول و الفقه وكتب القو اعد الأصــولية والفقهية والدراسات المتخصصة في الفتوى، وموضو ع البحث دن المباحث

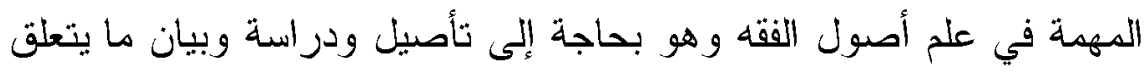

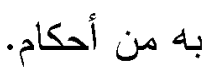

وقد قمت بجمع المسائل المتعلقة بالخطأ في الفتوى من مصادرها المعتمدة،

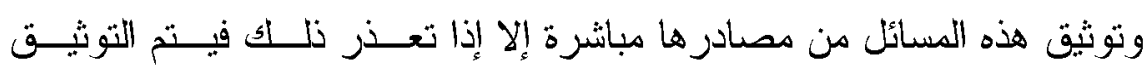

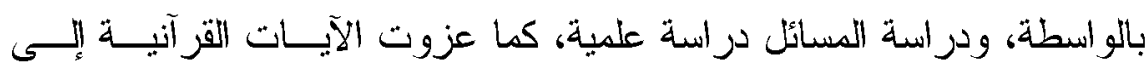
سور ها، وخرجت الأحانيث النبوية، وذكرت دعلومات مختصرة لمؤلفي دصادر البحث ورراجعه في الحاشية خشية الإطالة والإتقال.

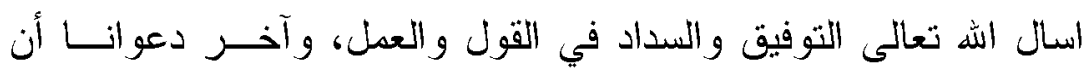

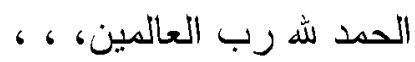


مجلة كلية الدراسات الإسلامية والعربية للبنات بدمنهور العدد الخامس الجزء التاسع •r+rم

المبحث الأول: التعريف بمصطلحاث البحث

لما كانت معرفة الشيء فر عا عن تصسـوره لـزم توضسـيح دعساني

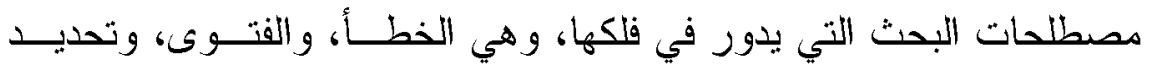
المقصود دنها، وما رسمه علماء أصول الفقه لها، ثم بيان المقصود بالمفتي في الثريعة الإسلادية، وقد انتظم هذا المبحث في ثثلاثة مطالب، على النحو

المطلب الأول: حقيقة الخطأ.

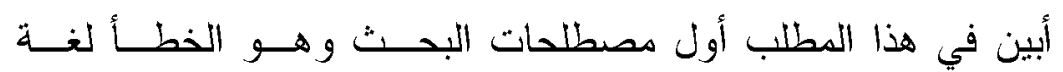
واصطلاحا، ما الذي يعنيه وها هي دعانيه التي يدل عليها، وما هي أقــوال الأصوليين في ذلك،، وذلك من خلال مسألتين على النحو الآتي: المسألة الأولى: تعريف الخطأ لغة.

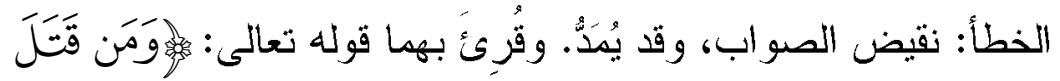

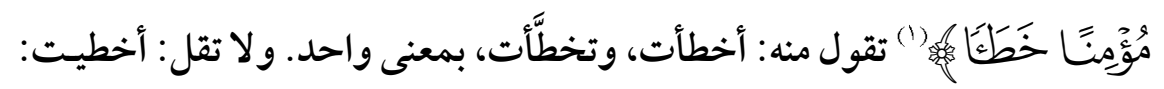

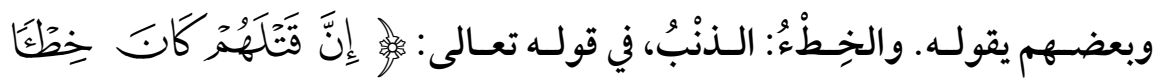
(T)( (1)

و المخطئ: من أر اد الصواب فصار إلى غيره، و الخاطئ هن تعدد ها

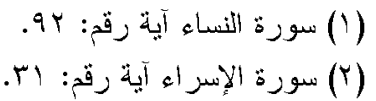

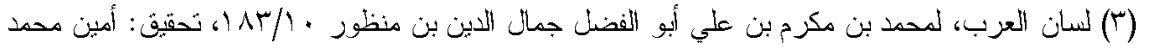

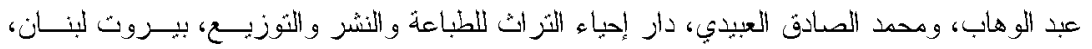

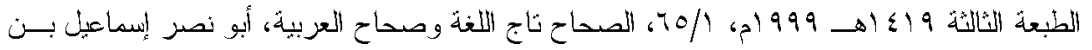

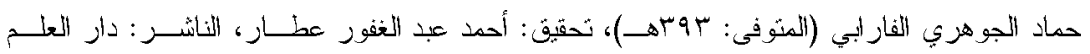

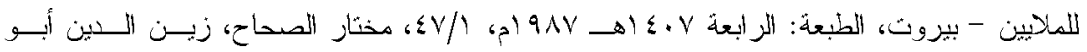

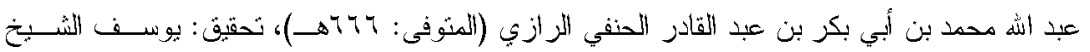

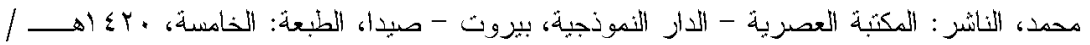

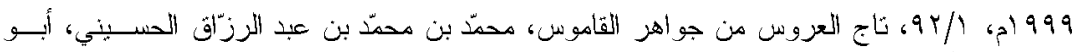

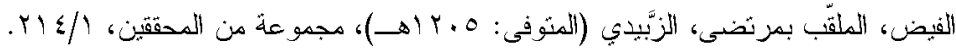




\section{لا ينبغي، وتخطأ له في الدسألة أخطأ)('). الفرق بين الخطأ و الغلط}

الغلط هُو وضع الثيء في غئ والطير موضعه ويجوز أن يكون صوابا في

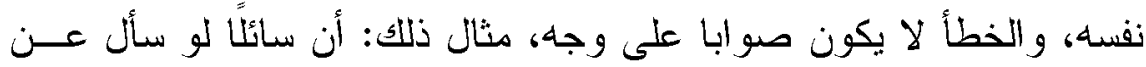

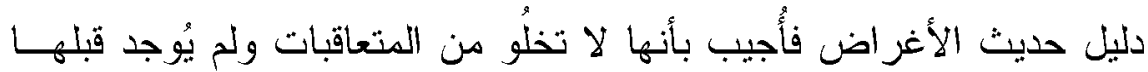

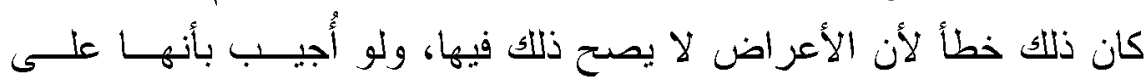

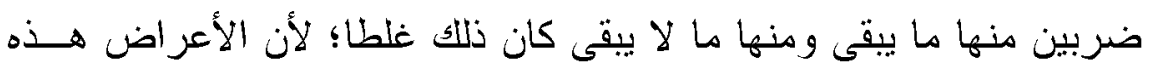

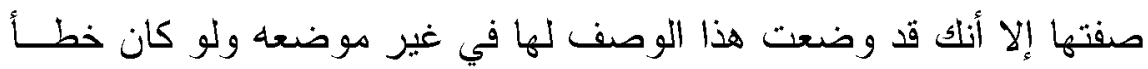

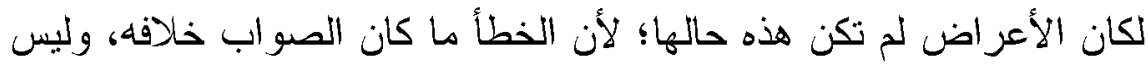

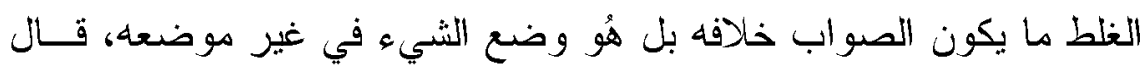

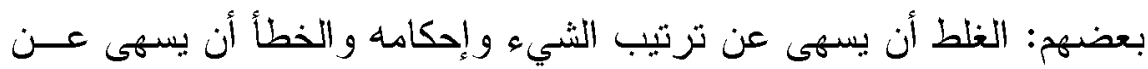

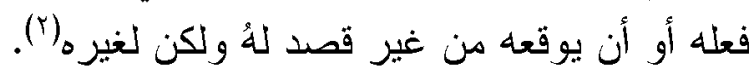
المسألة الثانية: تعريف الخطأ في الاصطلاح:

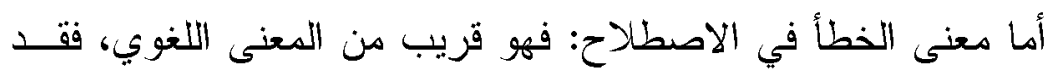

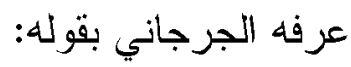

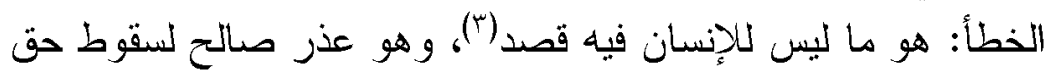

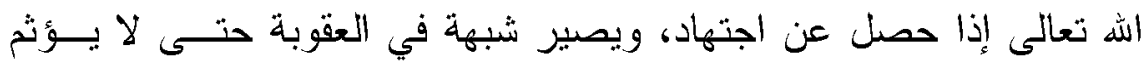

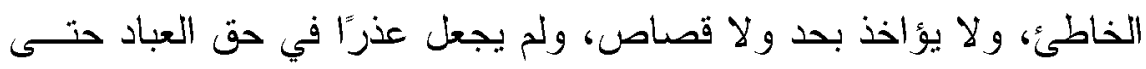

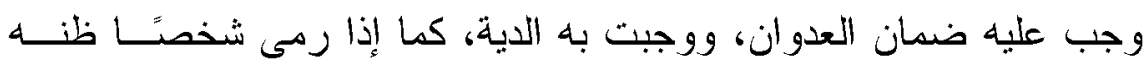

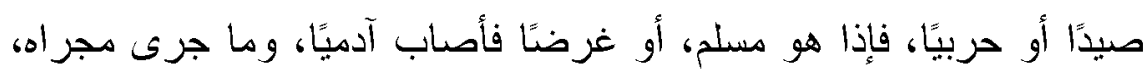

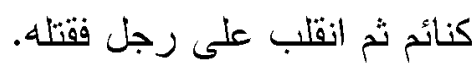

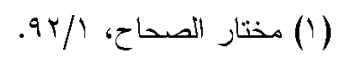

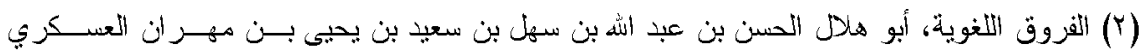

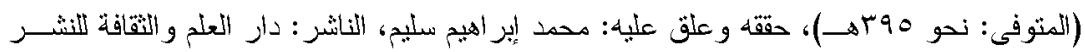

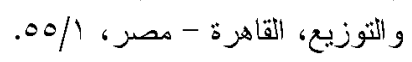

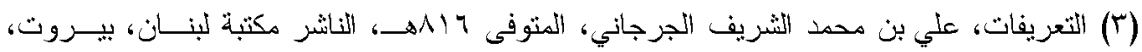


مجلة كلية الدراسات الإسلامية والعربية للبنات بدمنهور العدد الخامس الجزء التاسع •r+rم

وعرّة الحنفية بأنه: هو أن يقصد بالفعل غير الدحلّ الّذي يقصد به

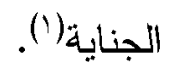

وقال الحافظ ابن رجب: الخطأ: هو أن يقصد بفعله شيئًا فيصادف فعله

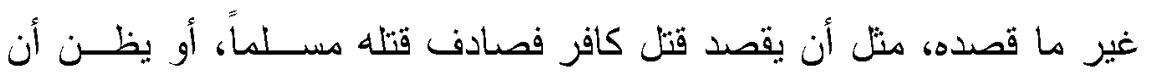

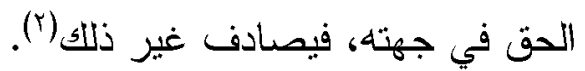

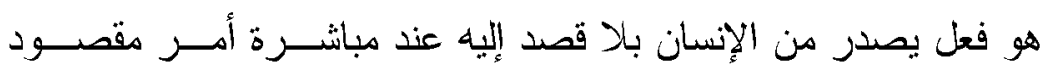
سواه) وقيل: الخطأ فعل أو قول يصدر عن الإنسان بغير قصده بسبب ترك التبت عند دباشرة أمر مقصود سواه(أ).

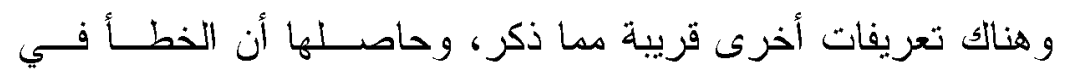

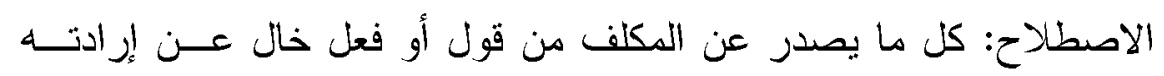
وغير مقترن بقصد منه.

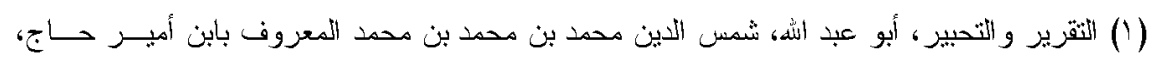

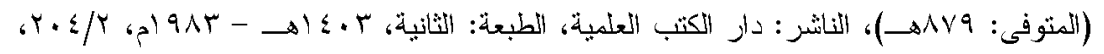

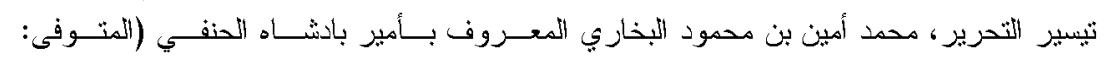

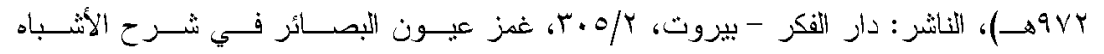

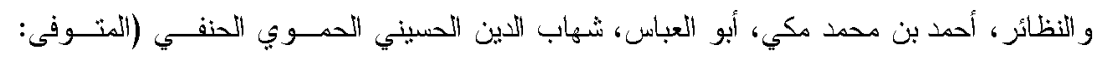

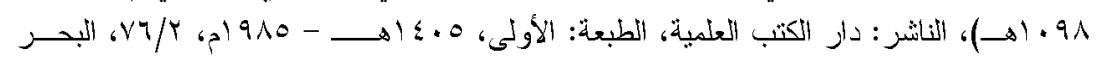

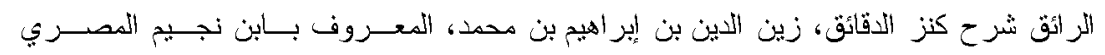

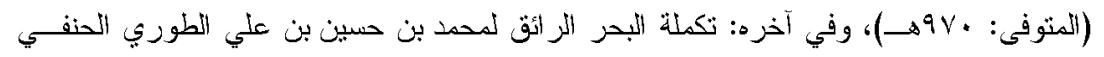

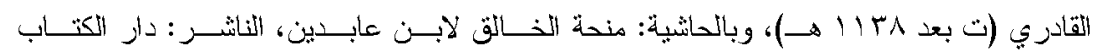

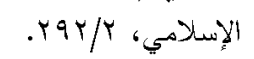

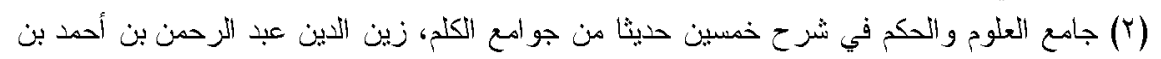

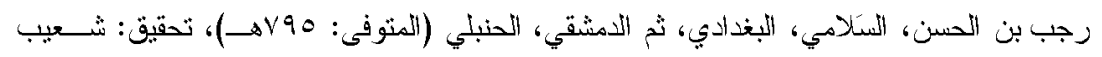

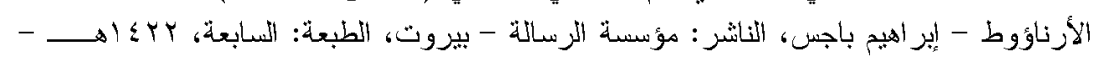

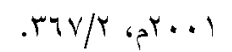

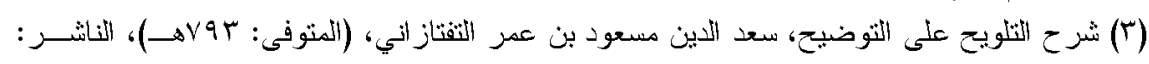

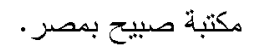

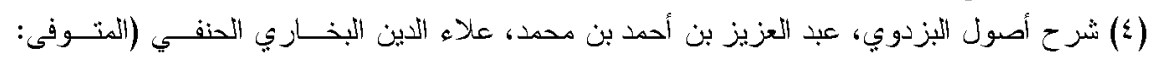

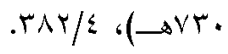




\section{المطلب الثاني: حقيقة الفتوى، وأهميتها.}

يتطلب البحث أيضا بيان حقيقة الفتوى في اللغة و الاصطلاح، وبيــان أهدية الفتوى، وحاجة الناس إليها، وقد لزم تقسيم هذا المطلب إلى مســألتين على نحو ما يأتي:

المسألة الأولى: تعريف الفتوى في اللغة والاصطلاح.

$$
\text { تعريف الفتوى في اللغة: }
$$

الفتوى اسم مصدر بsعنى الإفتاء، والجمع الفتاوَى والفتاوِي، يقــال:

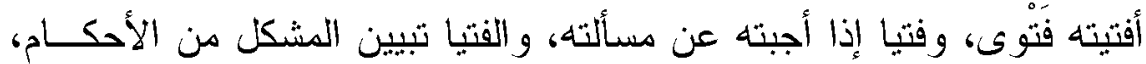

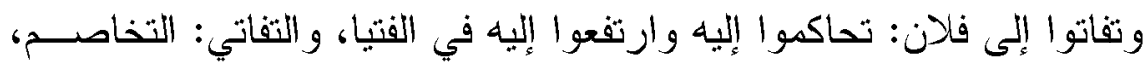

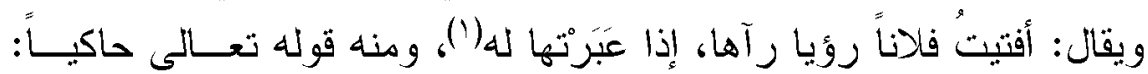

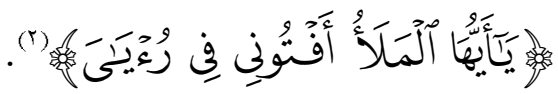

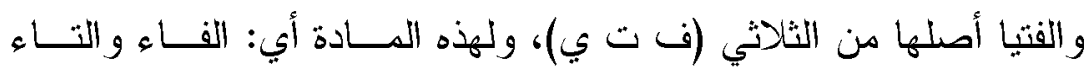
والحرف المعتل أصلان: أحدهما: يدل على طر اوة وجدَّة.

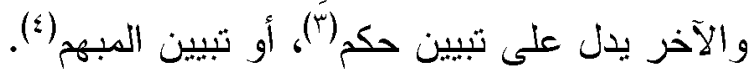

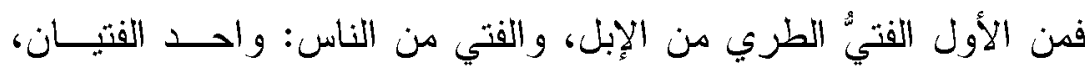

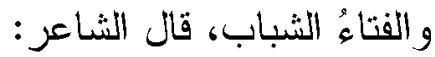

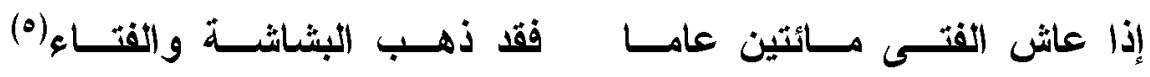

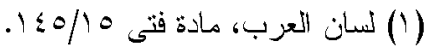

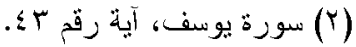

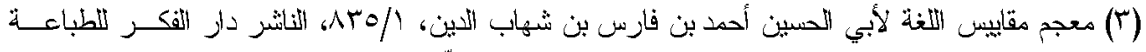

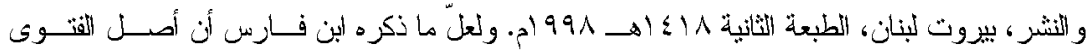

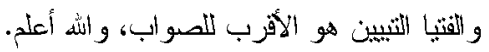

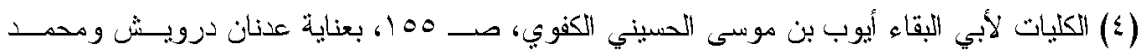

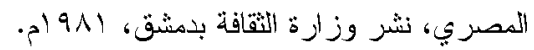

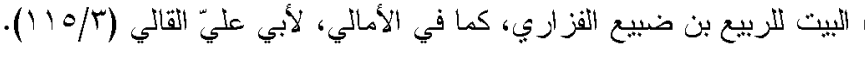


مجلة كلية الدراسات الإسلامية والعربية للبنات بدمنهور العدد الخامس الجزء التاسع •r+rم

ومن الأصل الآخر: الفتيا، يقال: أفتى الفقيه في المسألة إذا بين حكمها").

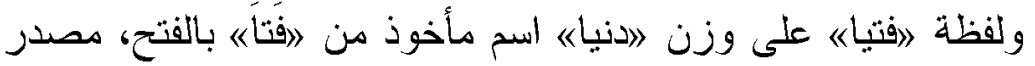

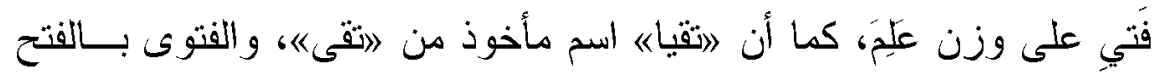

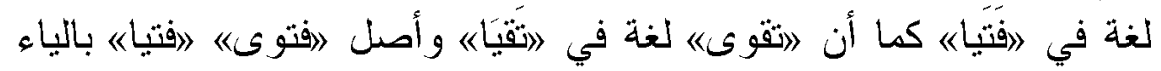
المقلوبة عن الواو للخفة في الاستعمال (r).

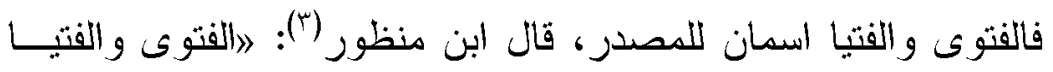

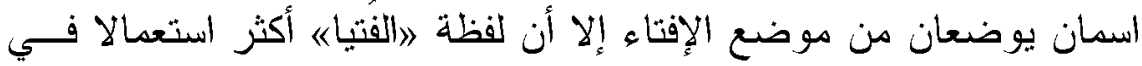

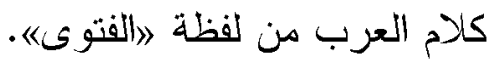

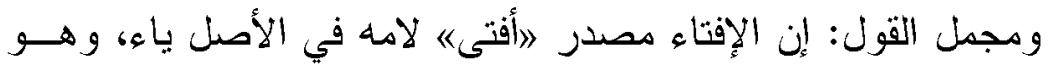

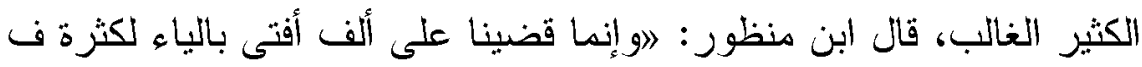
ت ب، وقلة ف ت و هاء).

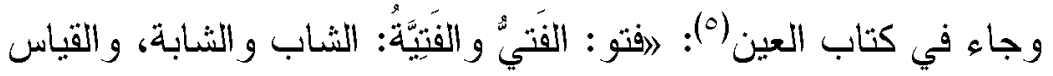

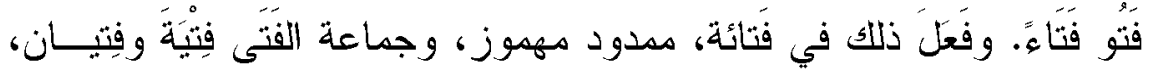

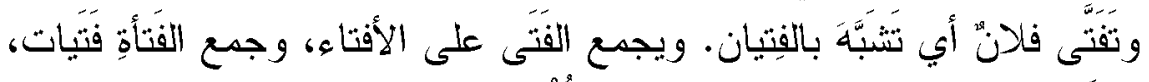

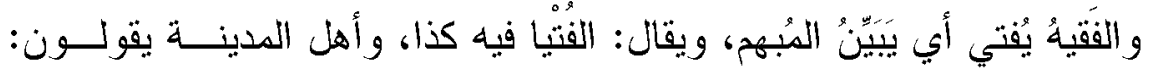
الفتوى《.

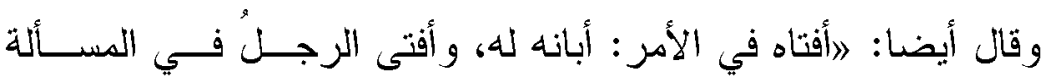

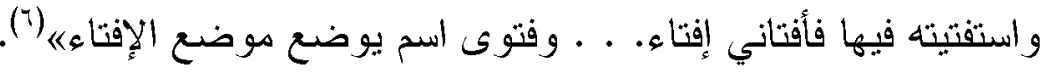

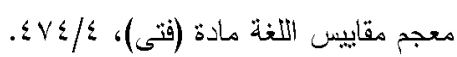

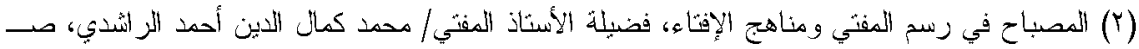

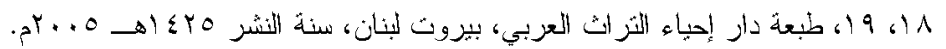

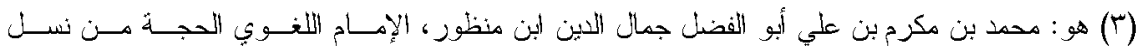

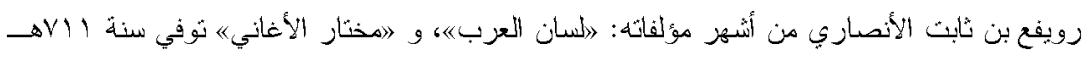

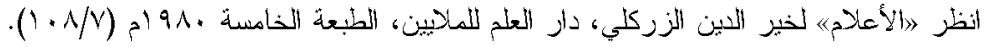

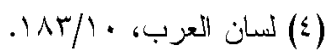

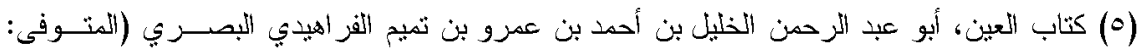

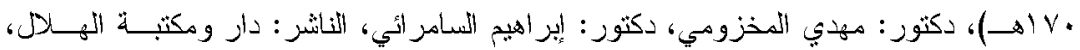


ويقال: أفتاه في المسألة يُفتيه إذا أجابه، والاسم الفَتُى، و الفُتيا تبيـين

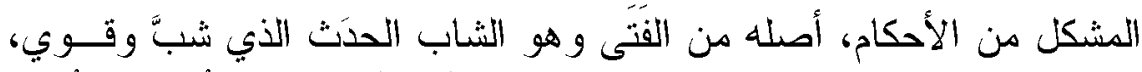

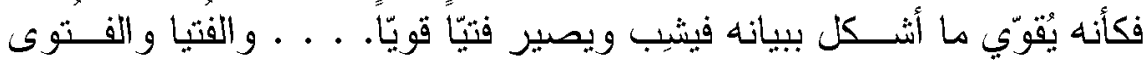
والفَـتـوى: ما أفتى بـه الفقيه.

هذا وإن دائرة الدعارف الإسلامية (الطبعة الإنكليزية الجديدة، مادة -

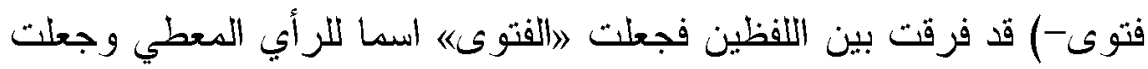

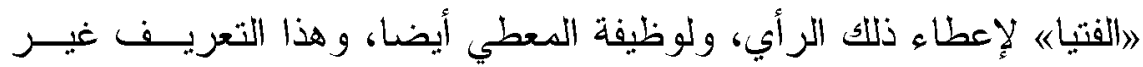

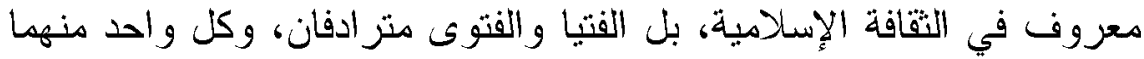
يصلح للرأي المعطي، و لإعطاء الرأي، ولوظيفة المعطي.

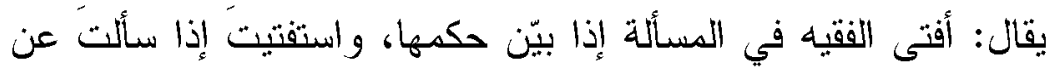

الحكم (') ( n

ويقال: أفتاه في الأهر : إذا أبانه له، وأفتى العالم إذا بين الحكم، وأفتى

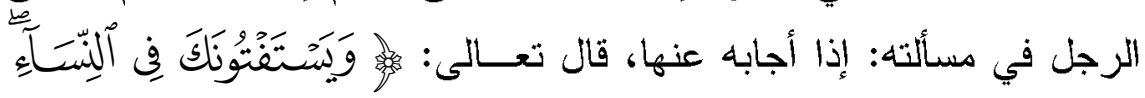

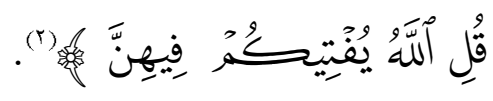

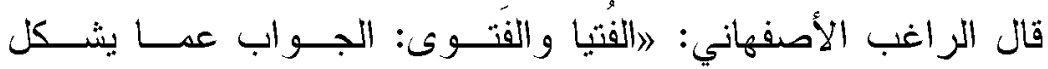

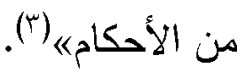
و الحاصل أن الفتيا أكثر استعدالا في لغة العرب من لفظ الفتوى. وقد ألف ابن فارس صاحب دعجم مقاييس اللغة رسالة أسماها: (رفتيا فقيه

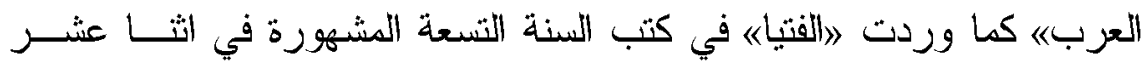

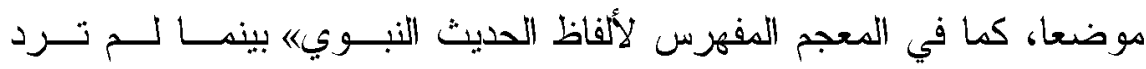

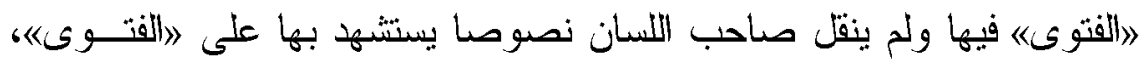

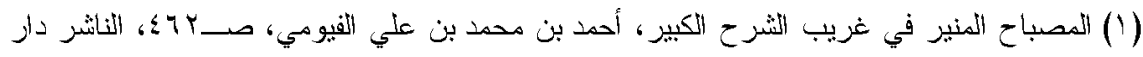

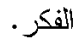

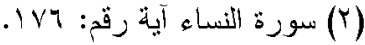

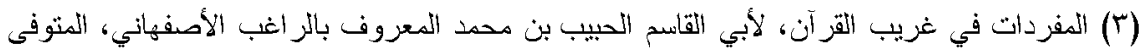

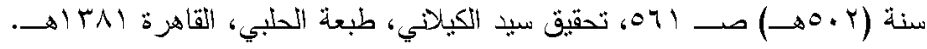


مجلة كلية الدراسات الإسلامية والعربية للبنات بدمنهور العدد الخامس الجزء التاسع •r+rم

فيحق لنا أن ندعي أن 》الفتيا《ه أفصح و إن كانت 》الفتوى《 لفظا فصــيحا ثقــة

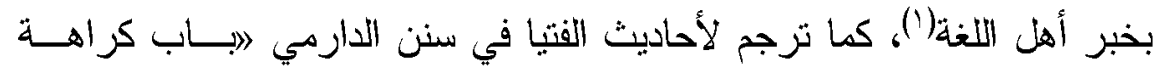
الفنيا《 في حين لم يرد ذكر 》الفتوى《 في كتب السنة المشهورة، وكثرة استعمال

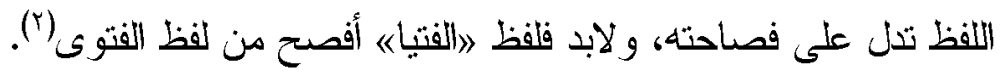
تعريف الفتوى في الاصطلاح:

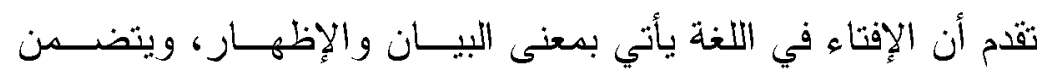

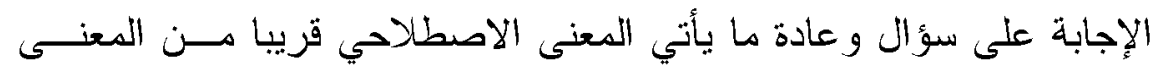

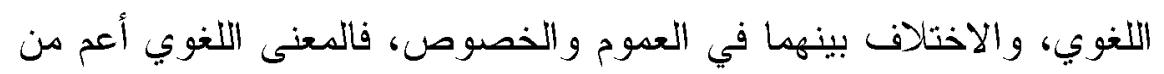

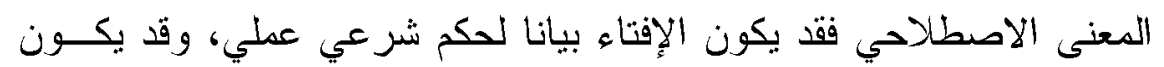

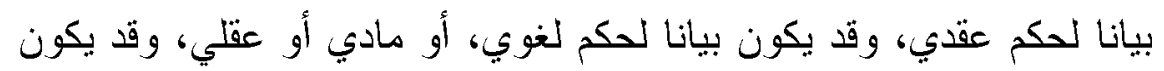

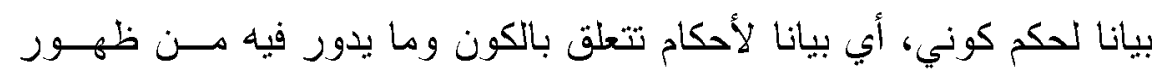

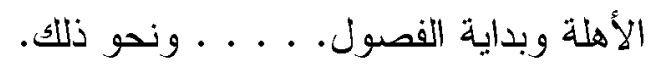

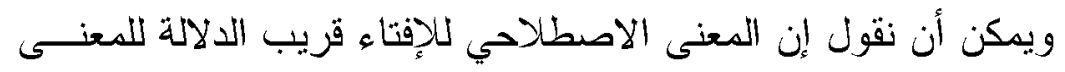

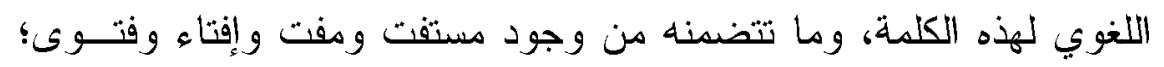

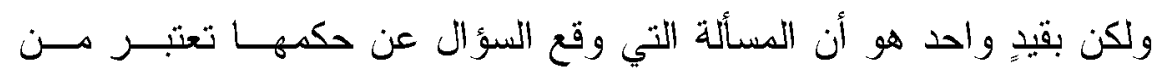

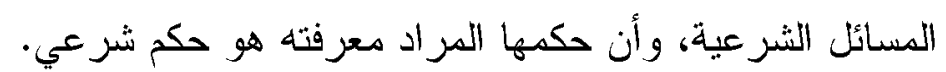

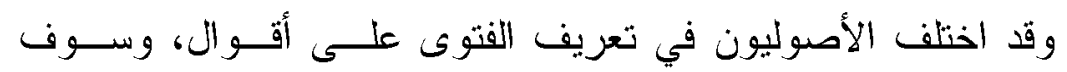
أعرض لأهم ها جاء في تلك التعريفات: عرفها الحنفية بأتها: بيان حكم المسألة (باء).

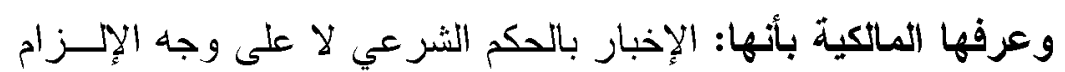
سواء كانت بكتب أو إخبار (ء).

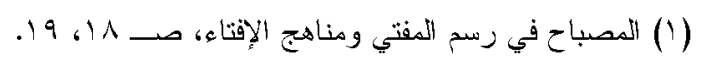

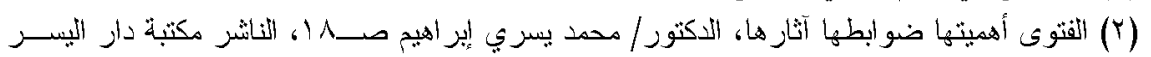
r

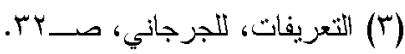

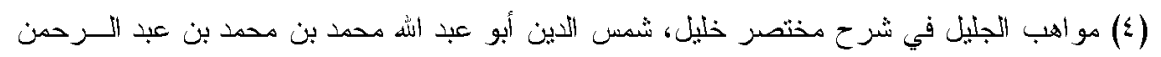

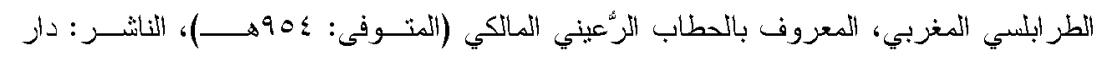
$=$ 
وقريب من ذلك قول القرافي بأنها: إخبار عن اله تعالى في إلزام أو

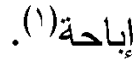

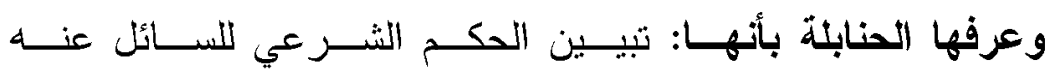

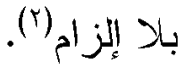

وقال ابن الجوزي: الفتوى تبيين المشكل من الأحكام("). قولهز: 》لا على وجه الإلزام) قيد للاحتراز عن القضاء؛ لأن القضاء فيه إلز ام بالحكم الثرعي.

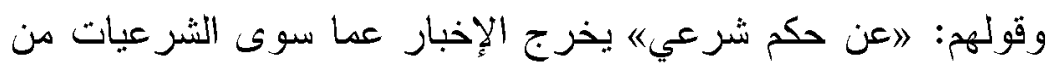

الفتوى؛ لأن الفتوى في الأصل تختص تهن بأحكام الثريعة.

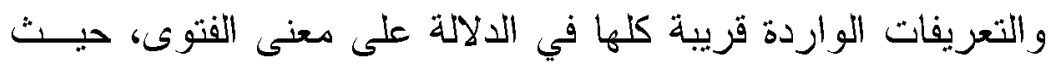

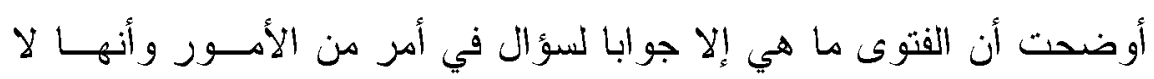

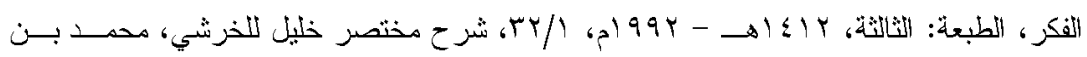

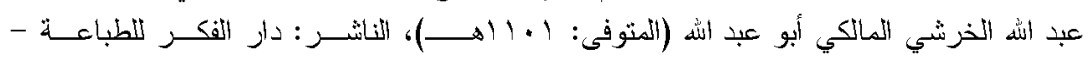

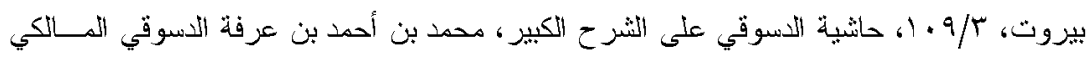

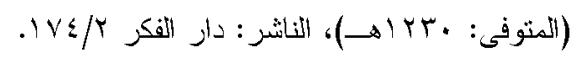

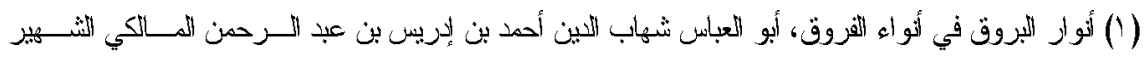

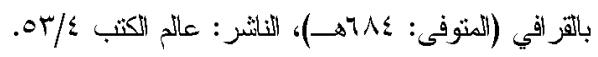

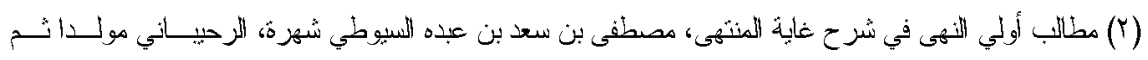

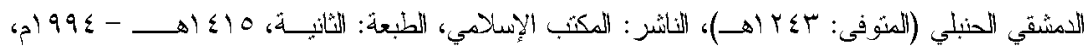

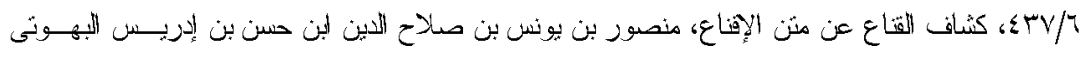

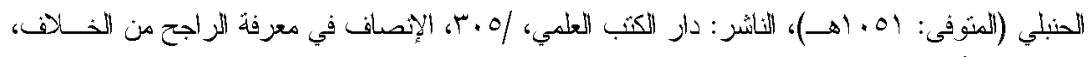

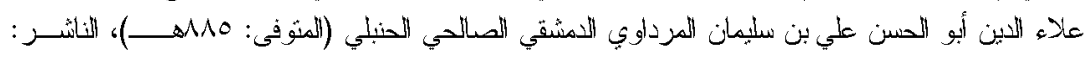

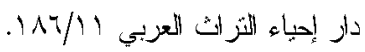

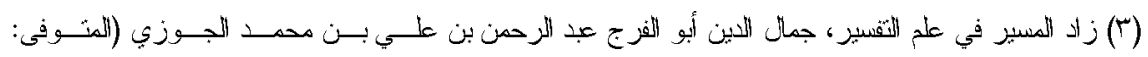

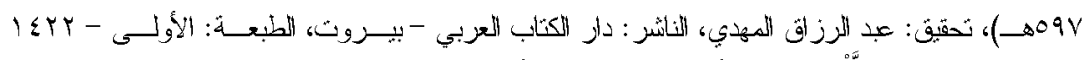

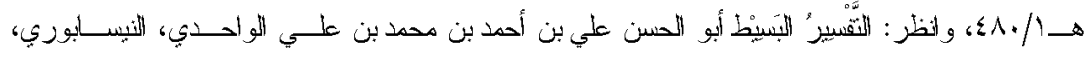

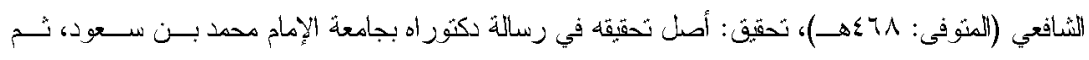

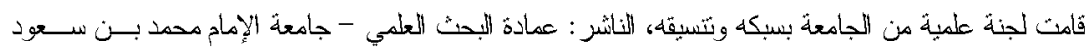

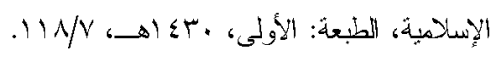


مجلة كلية الدراسات الإسلامية والعربية للبنات بدمنهور العدد الخامس الجزء التاسع •r+rم

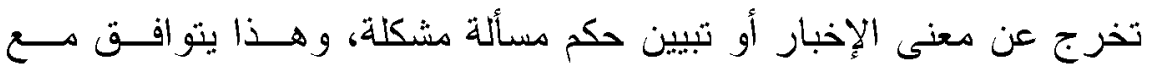

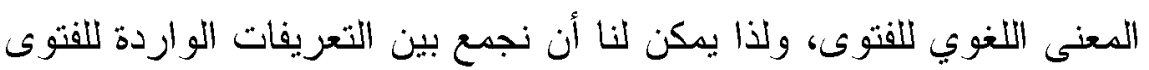

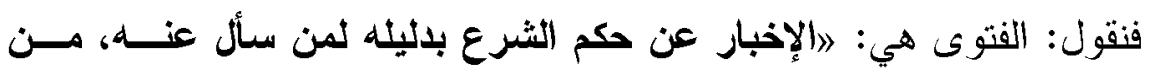
غير إلزام بهاه.

وبذلك نكون قد أخرجنا من التعريف حكم الحاكم والقاضي؛ لأن هـ التس

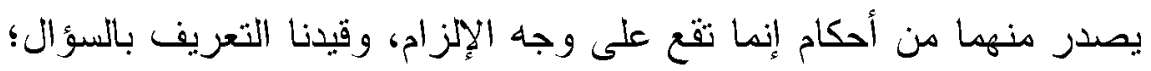

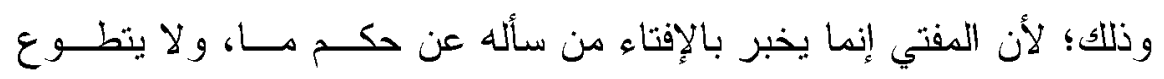
بالبيان كن قبل نفسه. المسألة الثانية: أهمية الفتوى. فئه

الفتوى كما سبق تعريفها هي: 》الإخبار عن حكم الثرع عدليله لـــن سأل عنه، هن غير إلز ام بهه.

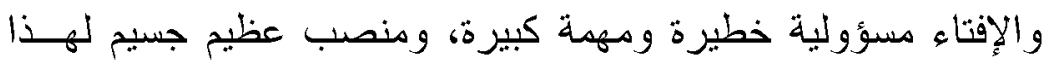

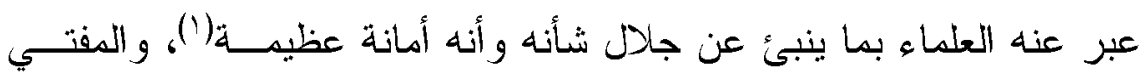

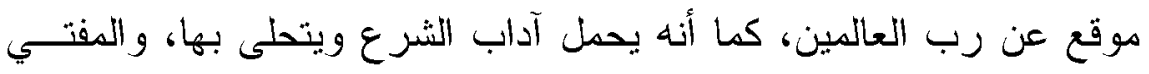

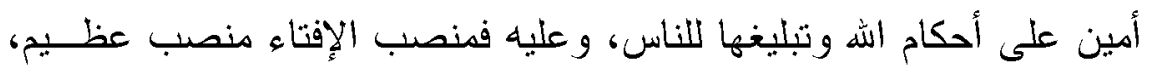

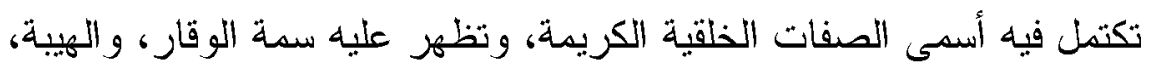

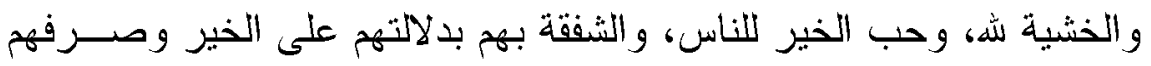

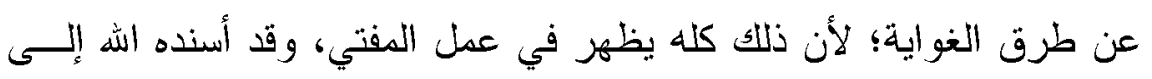

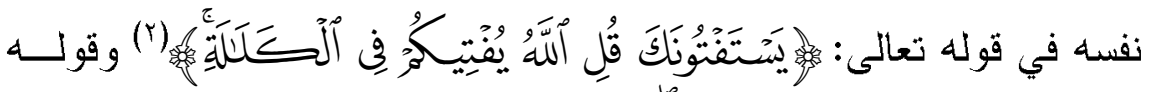

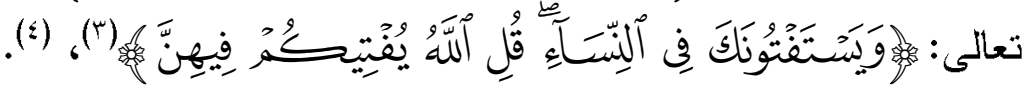

(1) المصباح في رسم المفتي ومناهج الإفتاء، فضيلة الأستاذ المفتي/ محمد كمال الدين أحمد اللرأشدي،

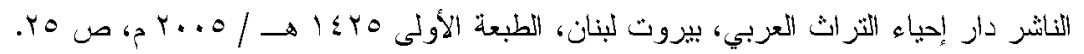

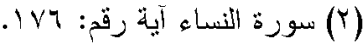
(Y)

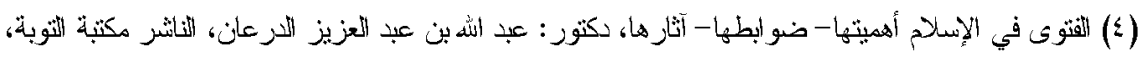

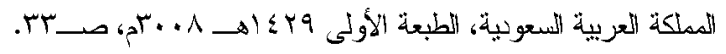




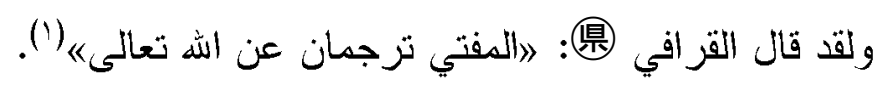

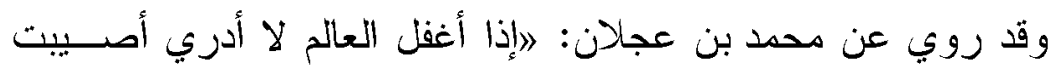

كتاتله

و هذا يبين أهمية الفتوى ويؤكد على خطورة أمر ها وعظم شأنها، ففيهــا

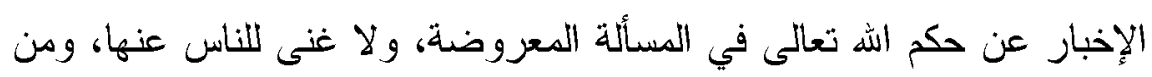

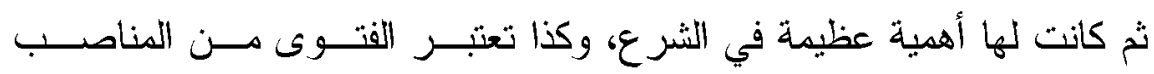

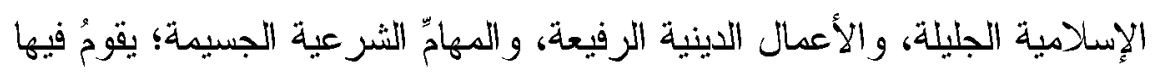

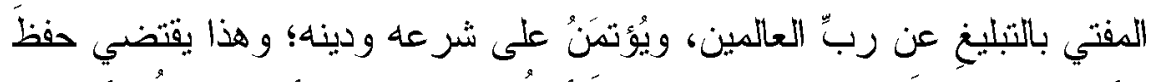

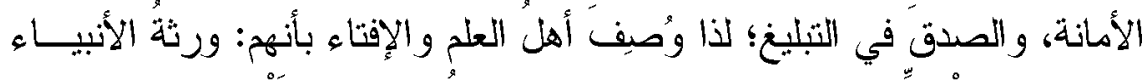

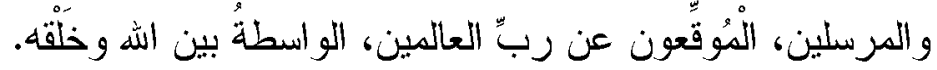

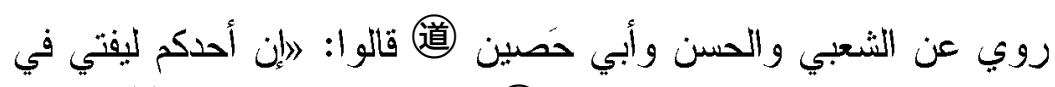

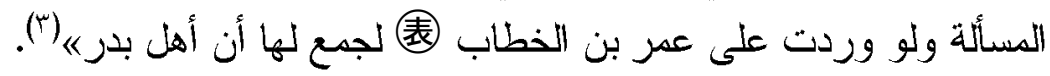

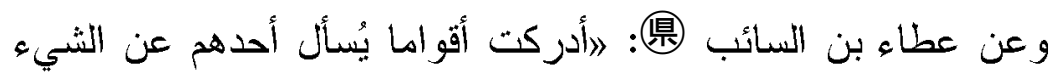

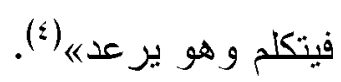

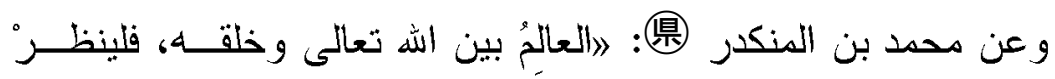
كيف يدخل بينهم) (0).

(1) الإحكام في تمبيز الفتوى عن الأحكام وتصرفات القاضي و الإمام، أحمد بن إدريس بن عبد الرحمن

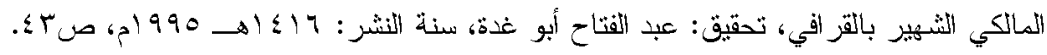

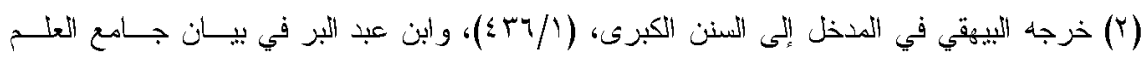

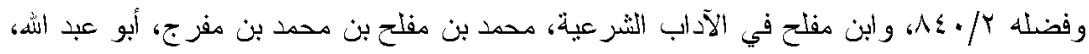

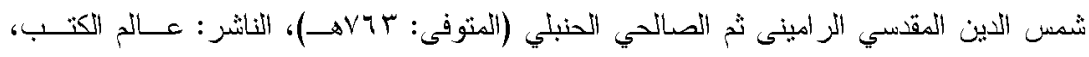

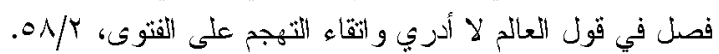

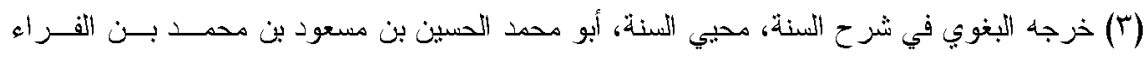

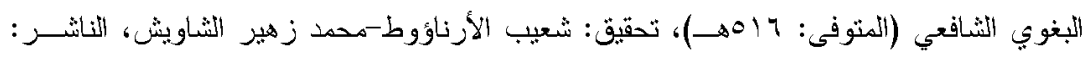

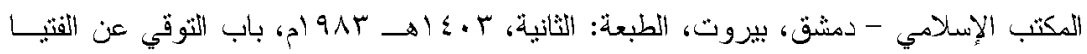

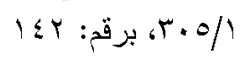

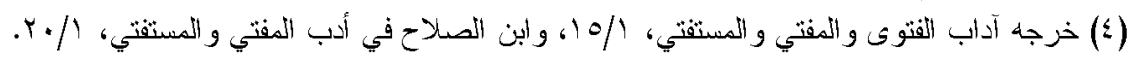

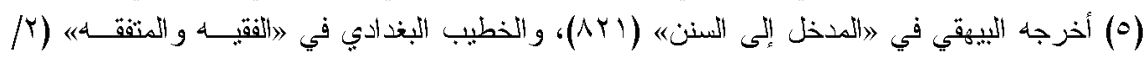

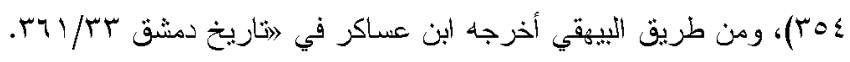


مجلة كلية الدراسات الإسلامية والعربية للبنات بدمنهور العدد الخامس الجزه التاسع •r+rم

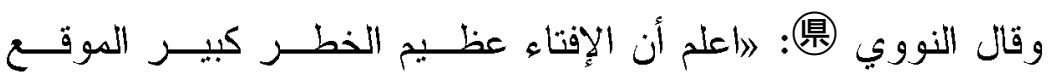

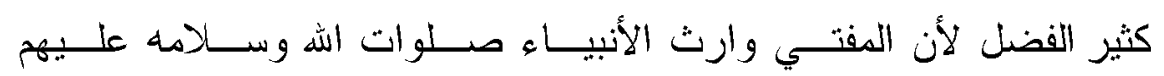

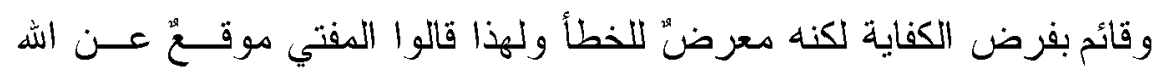

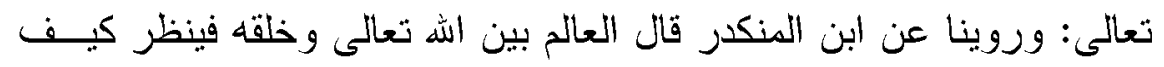
يدخل بينهم.

وروينا عن السلف وفضلاء الخلف دن التوقف عن الفتيا أنشياء كثيرة:

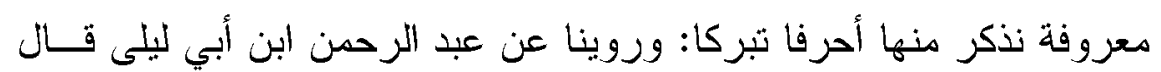

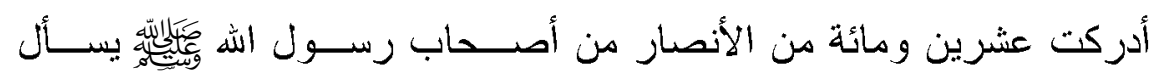
أحدهم عن المسألة فيردها هذا إلى هذا وهذا إلى هذا حتى ترجع إلى الأول.

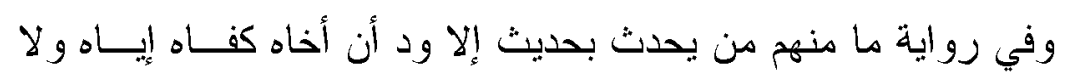

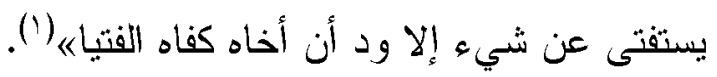

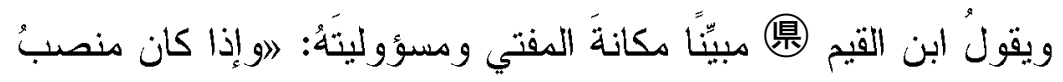

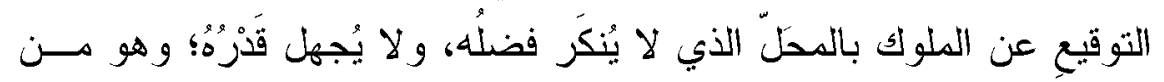

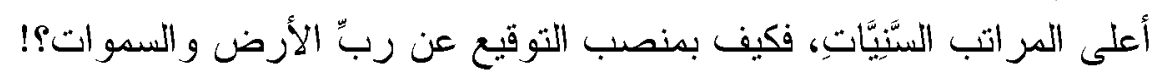

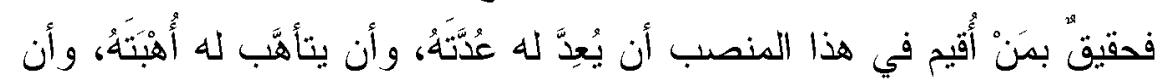

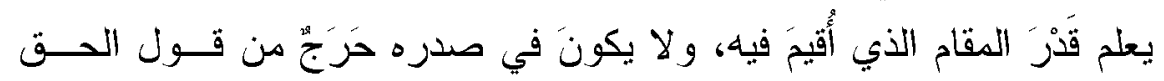

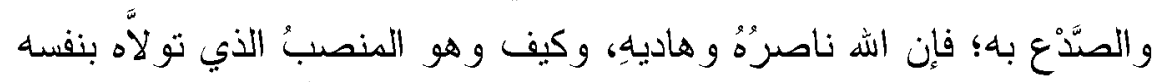

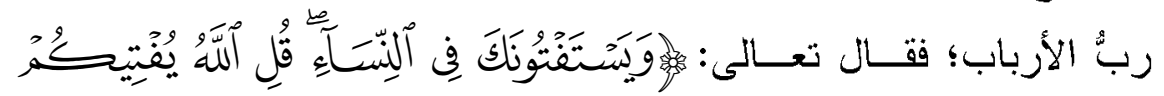

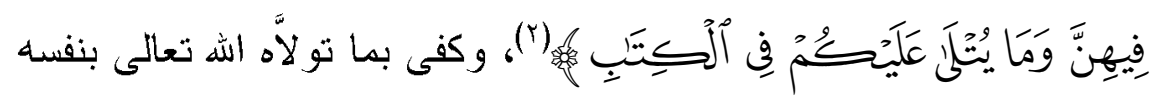

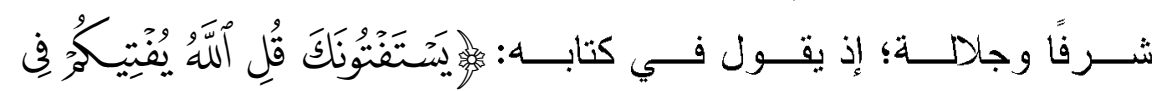

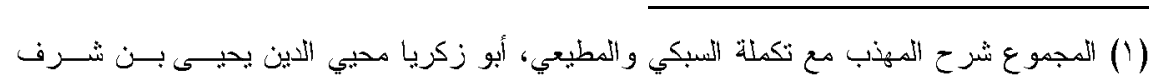

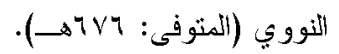

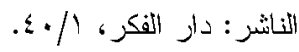

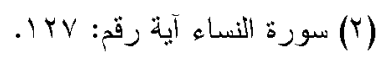




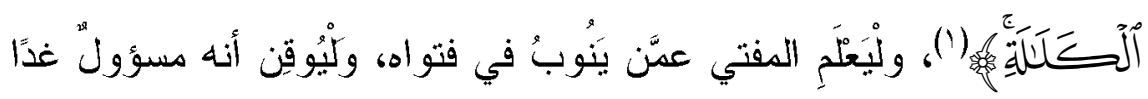
وموقوف بين يذَي الهُ (r).

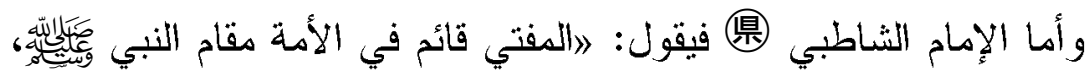
و الدليل على ذلك أمور:

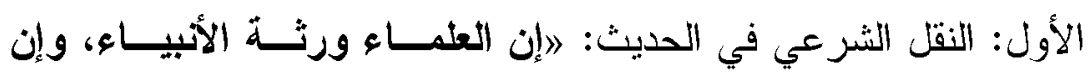

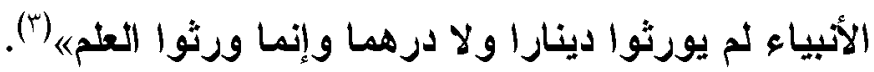

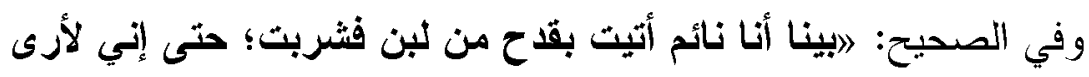

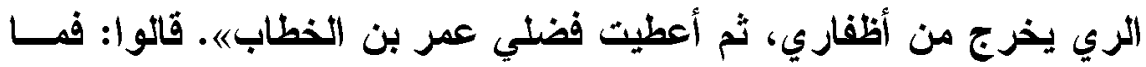

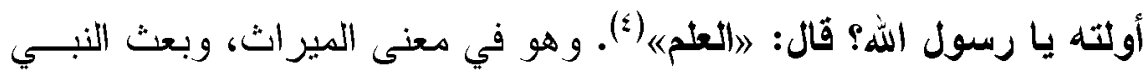

(1) (1) سورة النساء آية رقد: IVY)

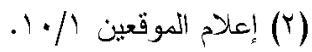

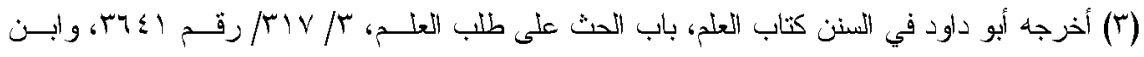

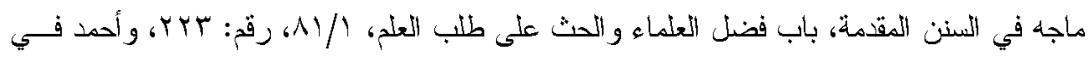

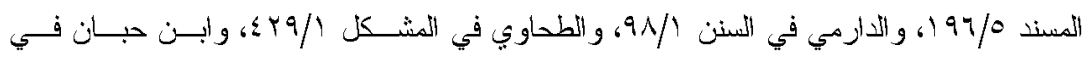

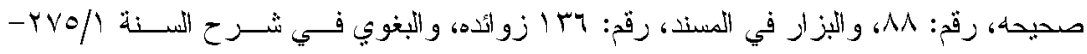

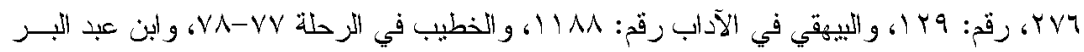

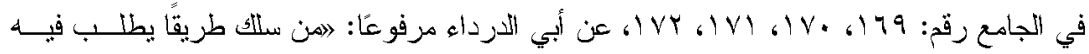

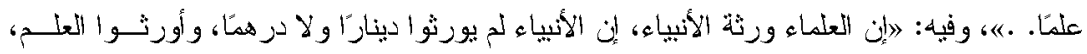

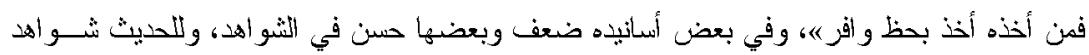

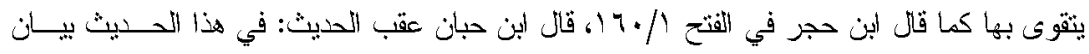

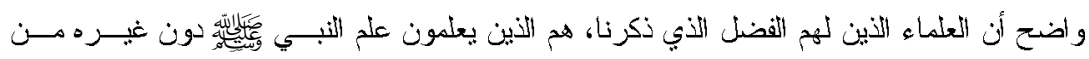

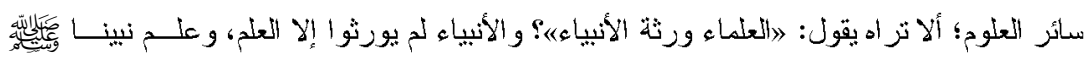
سنته، فمن تعرى عن معرفتها، لم يكن من ورثنة الأنيياء.

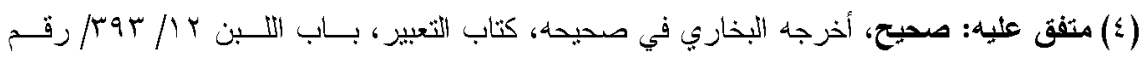

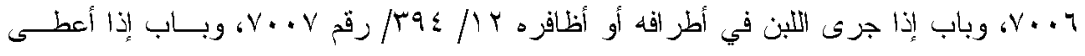

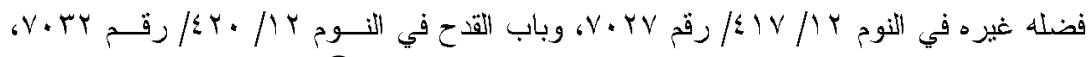

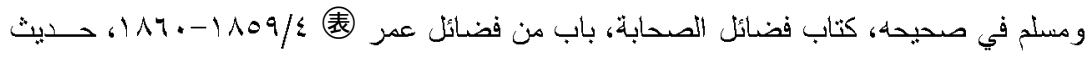

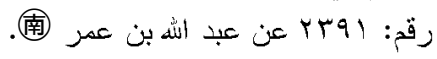


مجلة كلية الدراسات الإسلامية والعربية للبنات بدمنهور العدد الخامس الجزء التاسع •r+rم

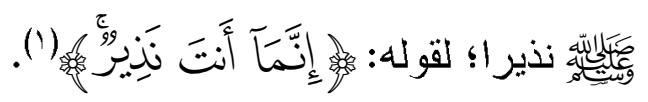

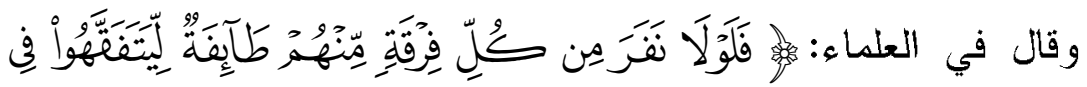

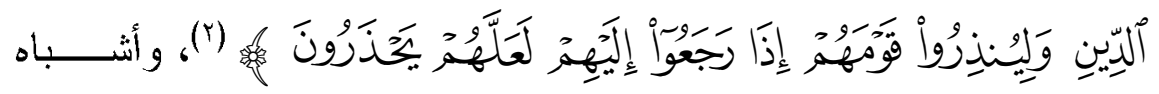

ذذ.

والثاني: أنه نائب عنه في تبليغ الأحكام؛ لقوله: 》ألا ليبغ الشـاهد منكم

(الخغائب

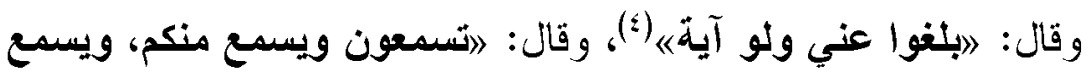

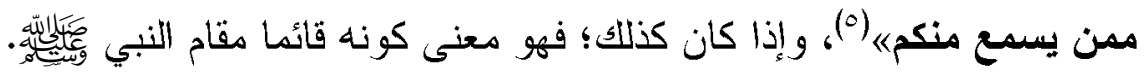

والثالث: أن المفتي شار ع من وجه؛ لأن ما يبلغه مــن الثتــريعة؛ إمــــا

دنقول عن صاحبها، و إما دستتبط دن المنقول؛ فالأول يكون فيــه مبلغــا،

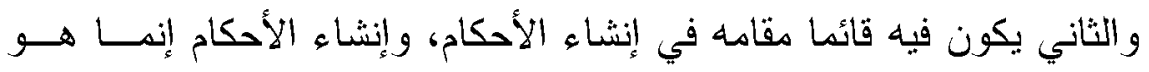
للثار ع، فإذا كان للمجته إنشاء الأحكام بحسب نظره واجتهاده؛ فهو هن هذا

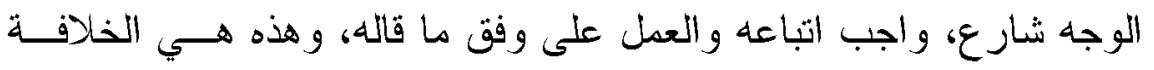
على و على الجملة؛ فالمفتي مخبر عن الله كالنبي، ودوقع للشريعة على أفعال

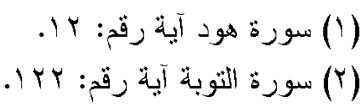

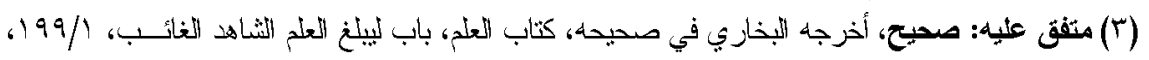

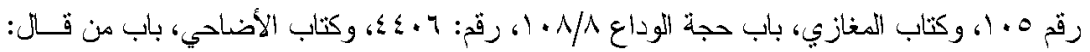

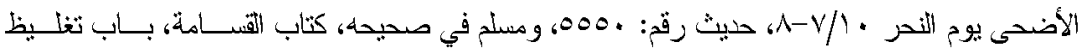

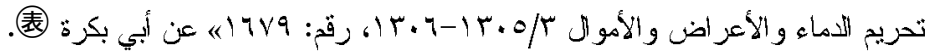

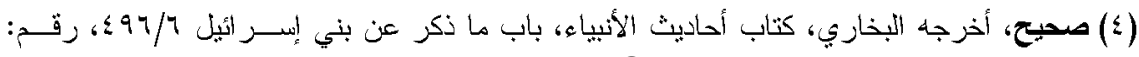

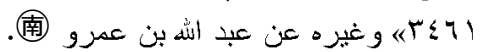

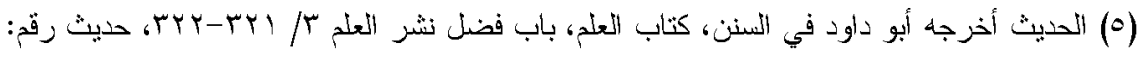

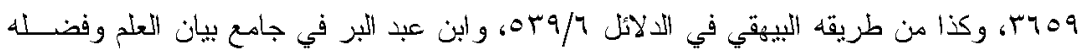

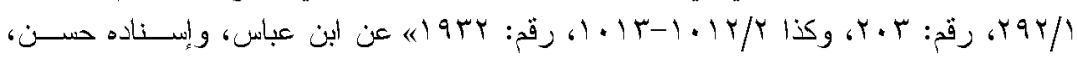

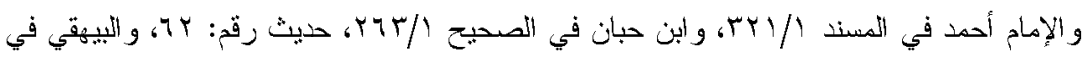

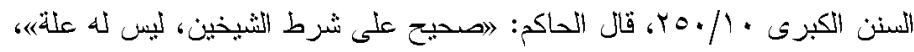


المكلفين بحسب نظره كالنبي، ونافذ أمره في الأمة بمنشور الخلافة كالنبي،

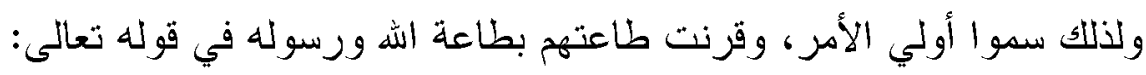

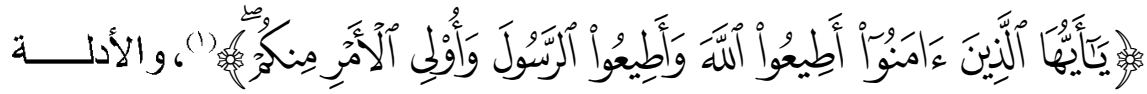
على هذا المنى كثيرة) (r). المطلب الثالث: حقيقة المفتي، ومكانته في الثريعة:

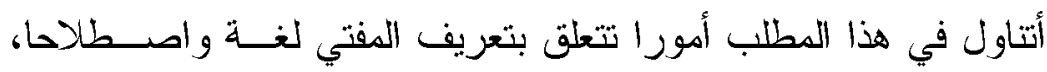

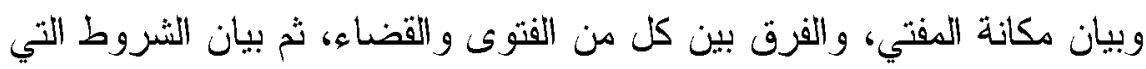
اشترطها الأصوليون في المفتي، وذلك من خلال المسائل الأربعة التالية: المسألة الأولى: تعريف المفتي في اللغة، والاصطلاح:

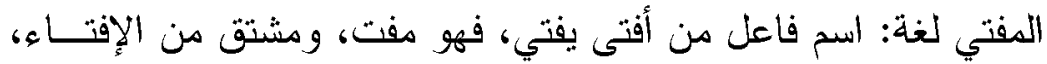

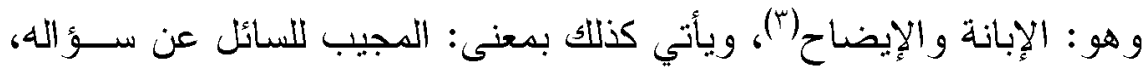

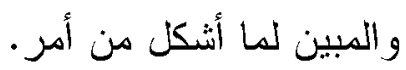

ولذا يقال: أفتيته في مسألة، إذا أجبته عنها(ئ).

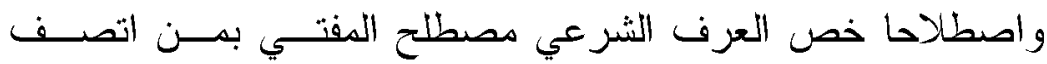
بالإفتاء في الثرعيات، ووقع هذا كثير ا، وقد تعددت التعريفات للمفتي فمنها

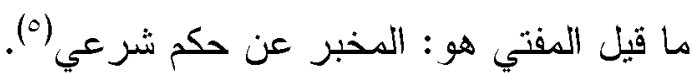

(1) (1) سورة النساء آية رقم: 09.

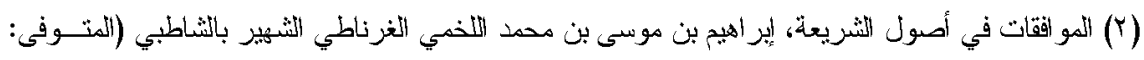

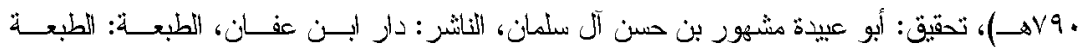

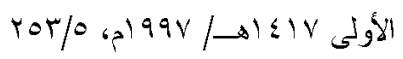

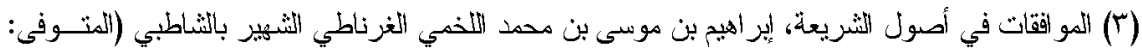

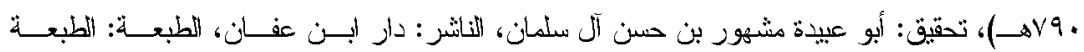

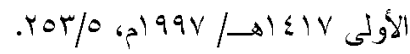

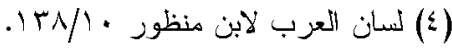
(0) التمهيد - شرح مختصر الأصول من علم الأصول، أبو المنذز محمود بن محمد بن مصطفى بـن عبد اللطيف اللمنياوي

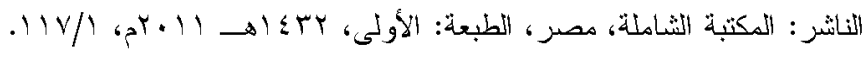


مجلة كلية الدراسات الإسلامية والعربية للبنات بدمنهور العدد الخامس الجزء التاسع •r+rم

وللأصوليين في تعريف المفتي اتجاهين: الأول: يعتبر أن المفتـي هـــو الهي

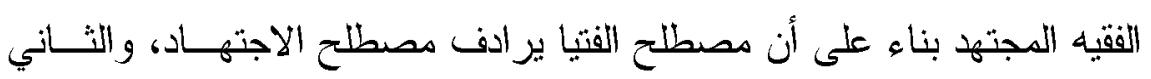

يفرق بين هفهومي الفتيا والاجتهاد، وننقل هنا عبار ات أصحاب الاتجاهين (') أما أصحاب الاتجاه الأول فمنها:

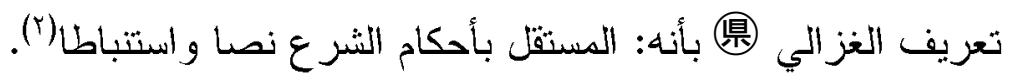

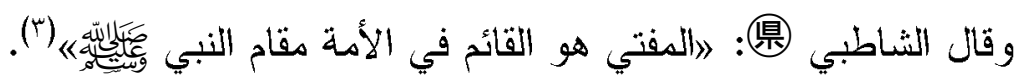

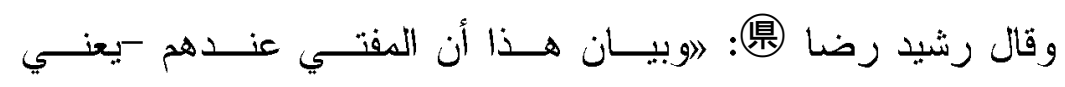

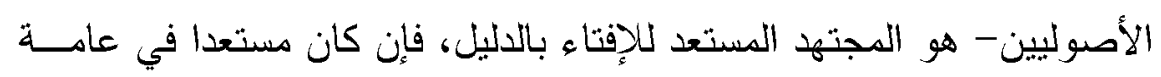
الأحكام فهو المجتهد المطلق، وإن كان لا يقدر إلا في بعض الأحكام فهـئ.

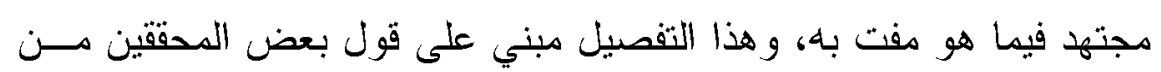
الأصوليين بأن الاجتهاد يتجز أيه (؛).

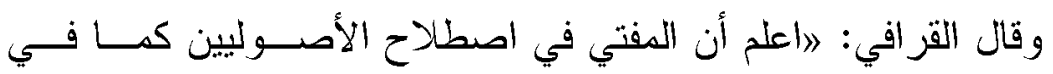

تحريز الكمال هو المجتهد المطلق وهو الفقيهی(ن).

وقال الصيرفي: 》هذا الاسم موضوع لهن قام للناس بأهر دينهخ وعلم

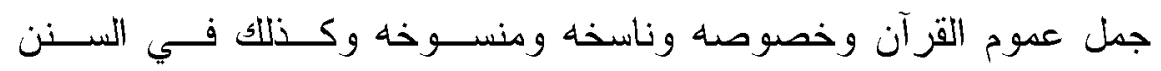

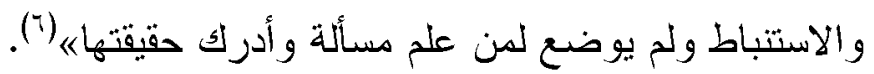

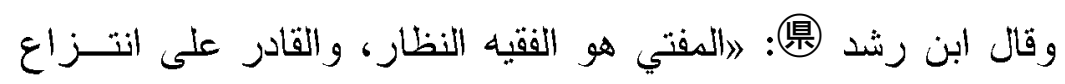

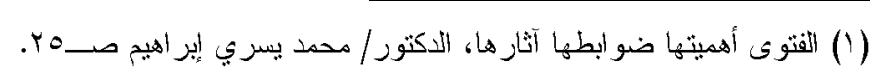

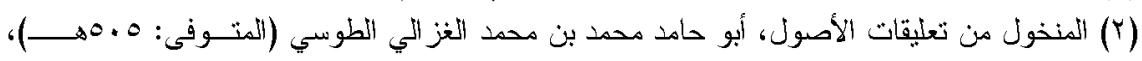

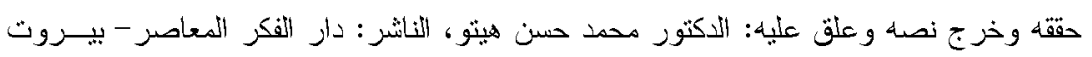

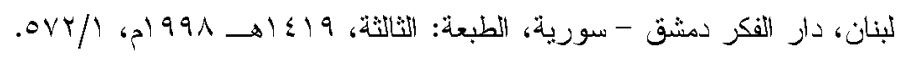

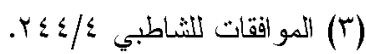

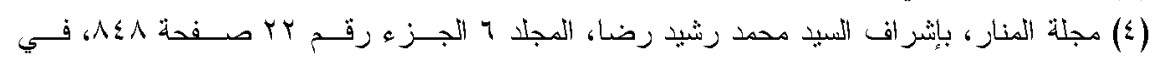

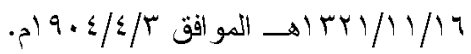

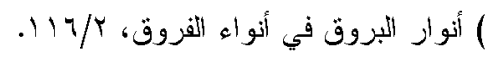

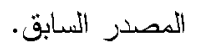


الأحكام الثرعية دن الكتاب و السنة والإجماع و القياسه(1).

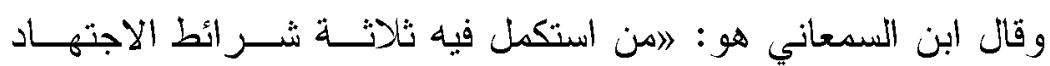

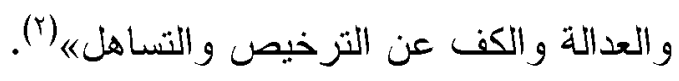

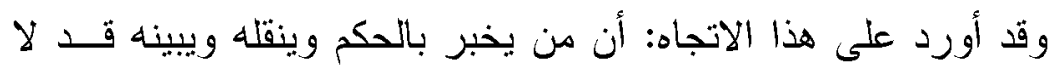

$$
\text { يكون مجتهدا، حيث ينقل عن غيره. }
$$

أجابو البالتريق بين الفتيا و الحكاية فمن أجاب غيره بناء علئ على ما سدعه

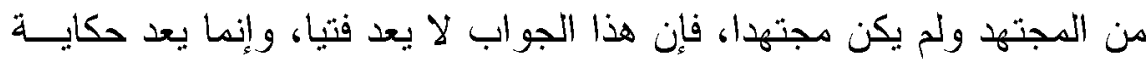
لقول المفتي المجتهد (ّ). وأما أصحاب الاتجاه الثاني، فيرون أن الإفتاء هو ثــــرة الاجتهــاد

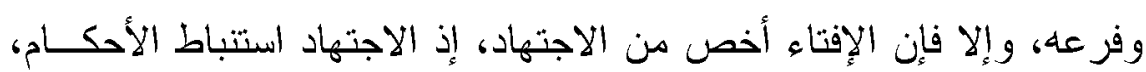

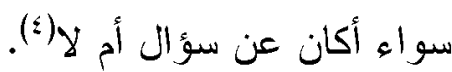
فمفهوم الإفتاء روعي فيه الإجابة بخلاف مفهوم الاجنهاد.

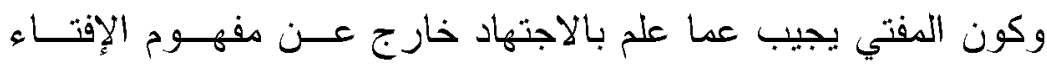

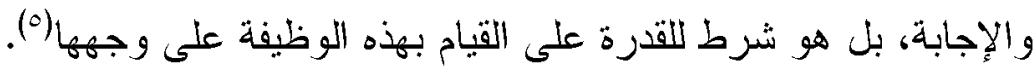

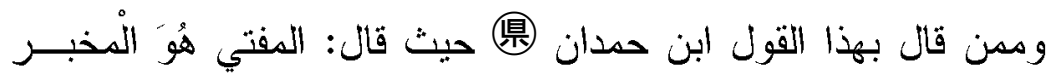

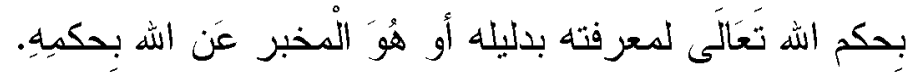

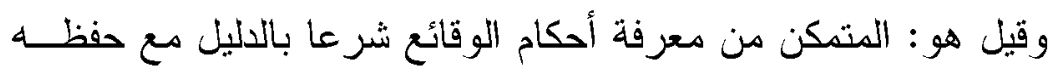

لأكثر الفقه (؟).

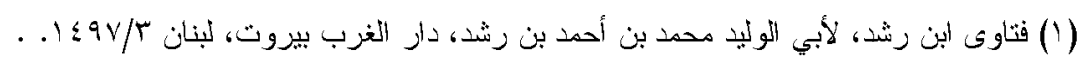

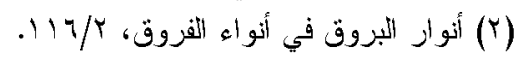

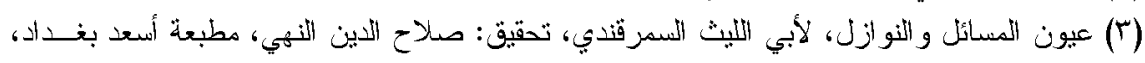

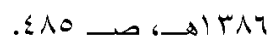

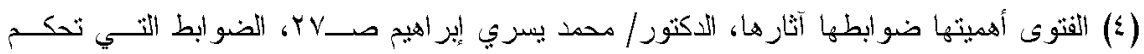

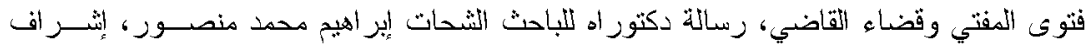

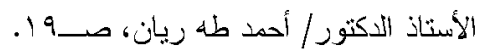

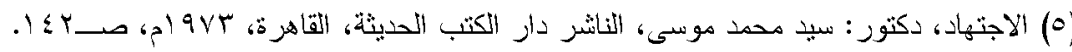

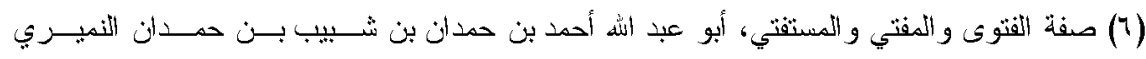
$=$ 
مجلة كلية الدراسات الإسلامية والعربية للبنات بدمنهور العدد الخامس الجزء التاسع •r+rم

والمرداوي (県)، حيث قال: 》المفتي من يبين الحكم الثرعي، ويخبر

به دن غير إلز ام (')

وفي الإبهاج شرح المنهاج: لهو المخبر بحكم الله تعسالى لمعرفتهـيه

بدليله «( )

ومع التسليم بأن المخبر عن هكم الله مجتهد، وأن الفتيا إنمـا تتـاط

بالمجتهدين، فكذلك ينبغي التشليم بأنه إذا عدم المجتهد اعتبر الأمثل فالأمثل في شأن الفتيا، ولهذا قال الفتوحي: 》اقال أكثر العلماء: يجوز لغير المجتهـــ أن يفتي إن كان مطلعا على المآخذ، أهلا للنظر «("). المسألة الثانية: مكانة المفتي في الثريعة.

المفتي هو الذي يظهر حكم الله تعالى في المسألة المعروضة عليه إيــا بالنص على ذلك من الكتاب أو السنة أو إجماع الأمة و إما باستتباط الحكـم

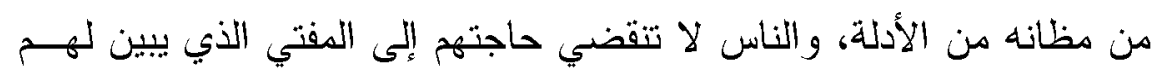
الحق هن الباطل، و الذي يدلهم على طريق الحق ويأخذ بأيديهم إليه، لذا كانت الحاجة إليه دهمة، ووجوده بين الخلق ضرورة يفرضــها كثــرة النــوازل

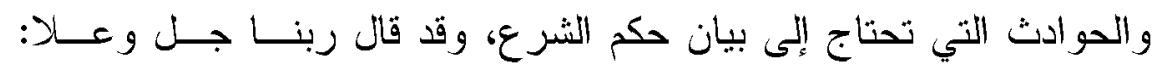

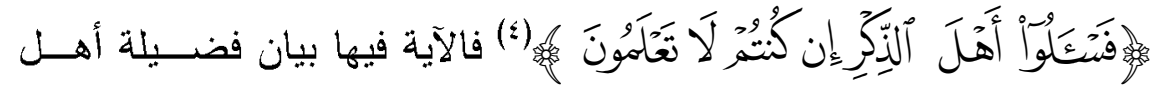
العلم، ولا شك أن أعلى أنو اعه: العلمُ بكتاب الله المنزل، فإن الله أمر دن لا

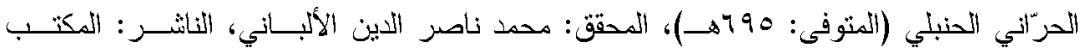

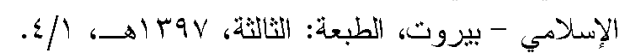

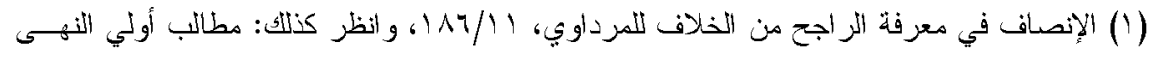

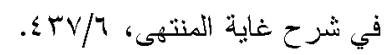

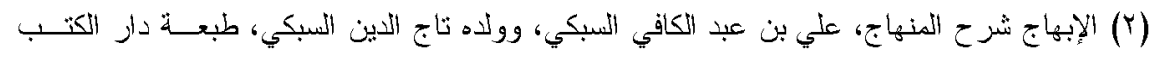

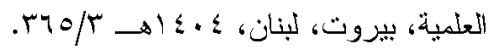

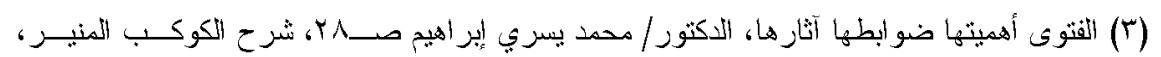
$.00 \mathrm{~V} / \mathrm{s}$ (؛) سورة النحل، جزء من الآية: بـ، وجزء من الآية رقم: V من سورة الأنياء. 


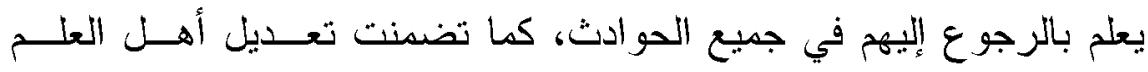

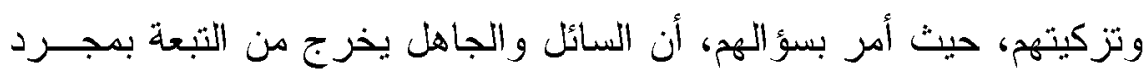

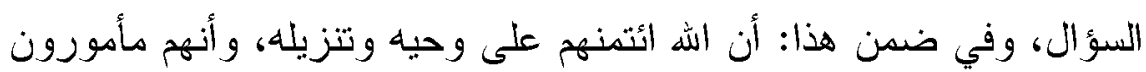

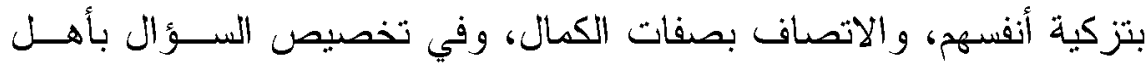

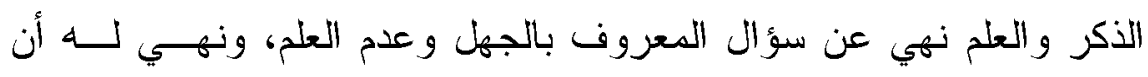
يتصدى لذلك.

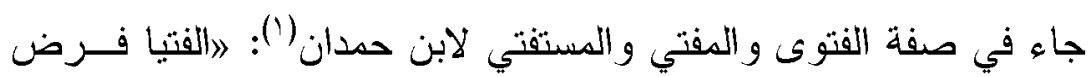
عين إذا كان في البلد هفت واحد وفرض كفاية إذا كان فيه دفتيــان فــأكثر

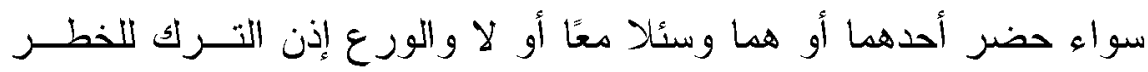

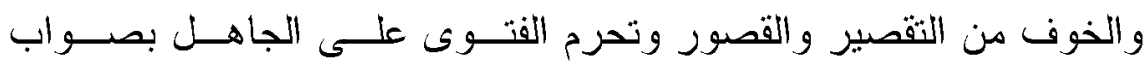

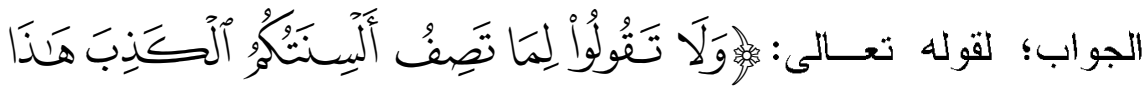

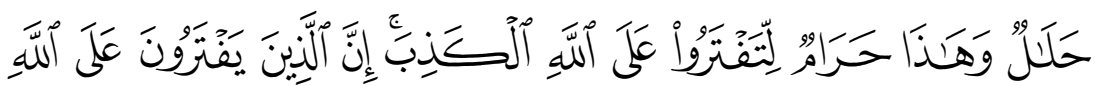

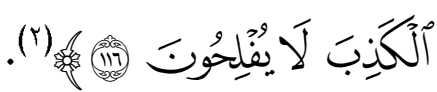


مجلة كلية الدراسات الإسلامية والعربية للبنات بدمنهور العدد الخامس الجزء التاسع •r+rم

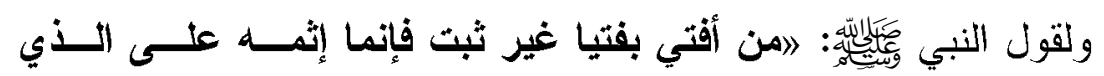

(أقتاهیا (1)

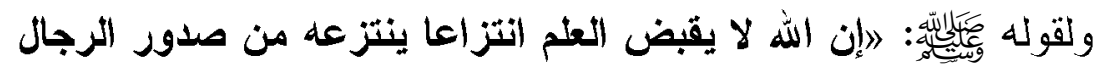

ولكن يقبض العلم بقبض العلماء، فإذا لم يبق عالم اتخذ التــاس رؤســاء

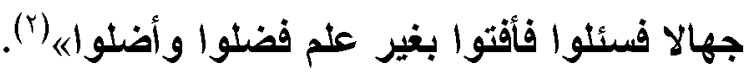

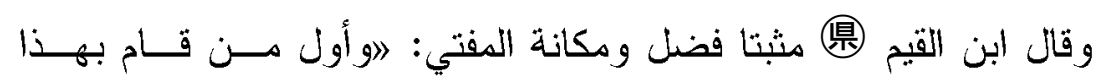

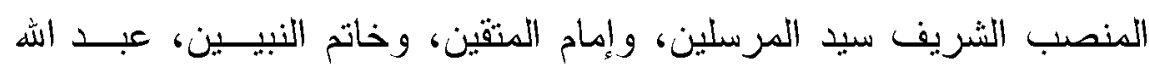

ورسوله، و أمينه على وحيه، وسفيره بينه وبين عباده؛ فكان يفتي عــن الله

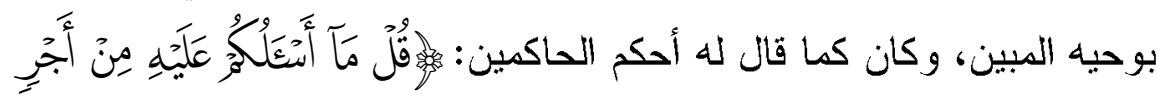

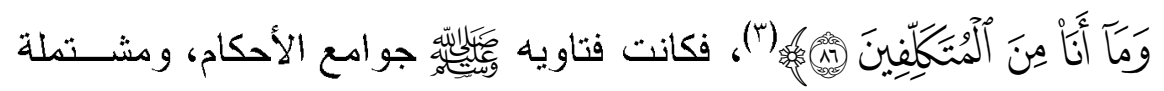

على فصل الخطاب، وهي في وجوب اتباعها وتحكيمها و التحاكم إليها ثانية الكتاب، وليس لأحد من المسلمين العدول عنها ما وجد إليها سبيلا، وقد أهر

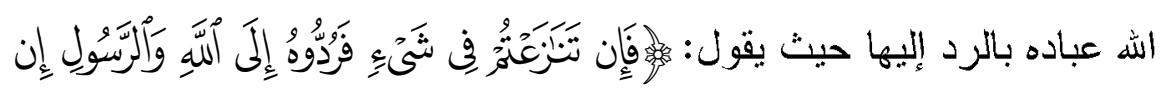

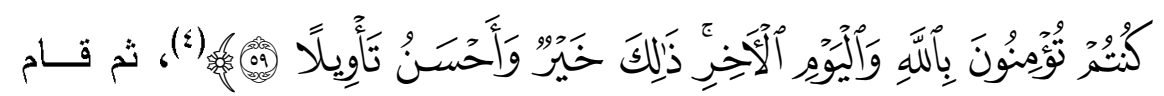
بالفتوى بعده برك الإسلام وعصابة الإيمان، وعسكر القرآن، وجند الرحمن،

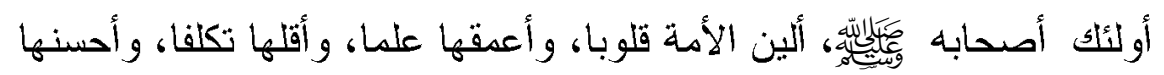

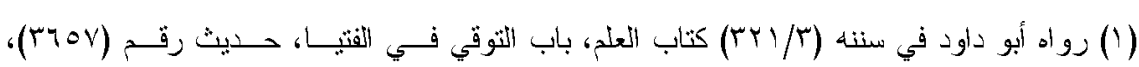

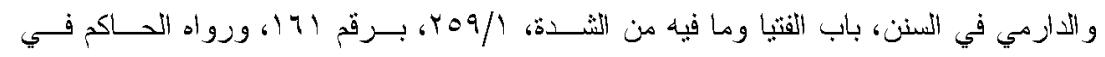

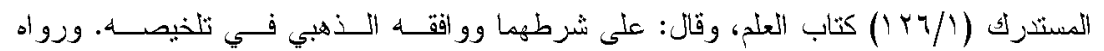
غير غئما.

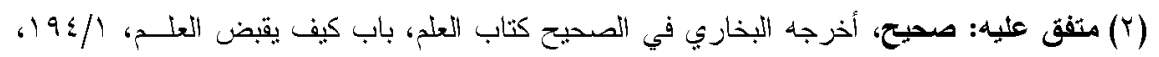

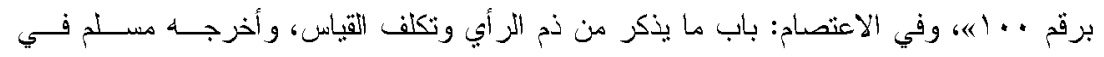

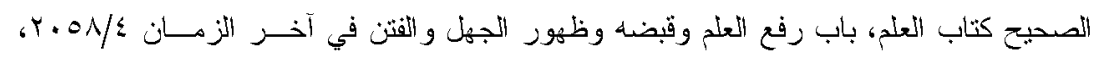

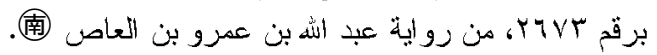

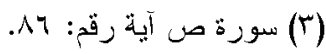

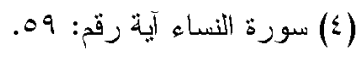


بيانا، وأصدقها إيمانا، وأعدها نصيحة، و أقربها إلى الله وسيلة، وكانو ا بـين مكثر دنها ومقل ومتوسطه (').

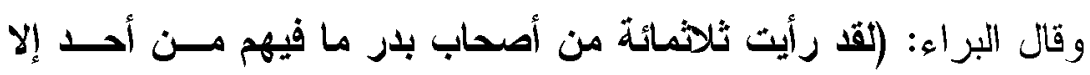

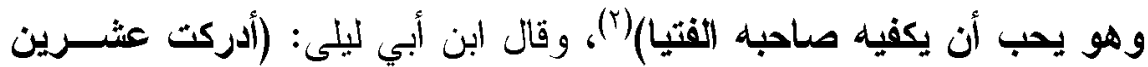

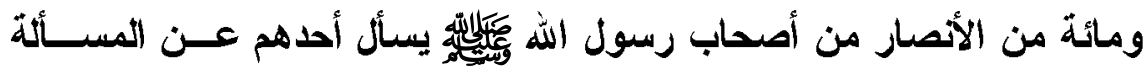

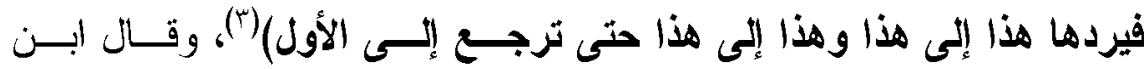

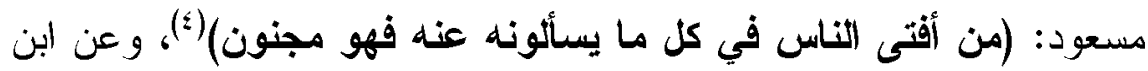

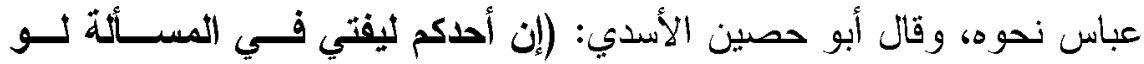

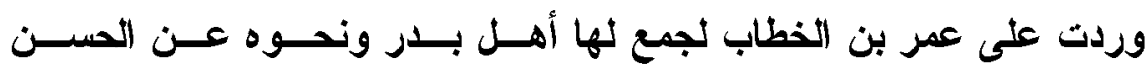
و الثشبي) (م)

وقال ابن الصلاح: في بيان شرف حرمة الفتوى وخطر ها، وغررهــا، روينا ها رواه أبو داود السجستاني، وأبو عيسى الترمذي، وأبو عبد الله ابن هين

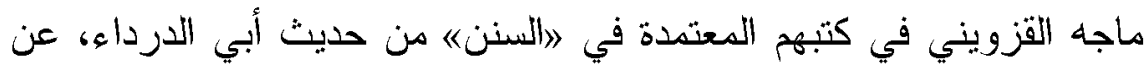

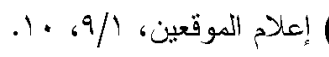

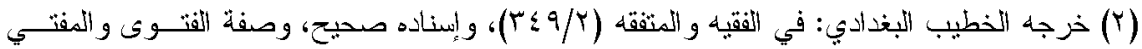

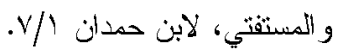

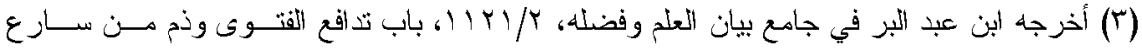

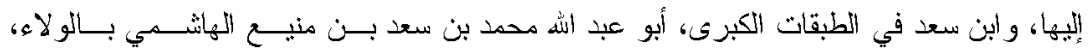

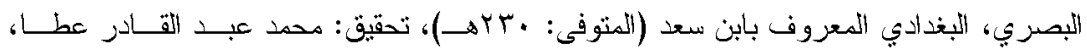

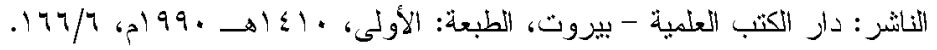

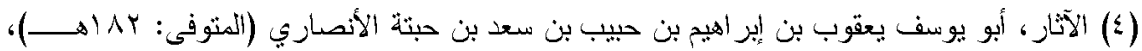

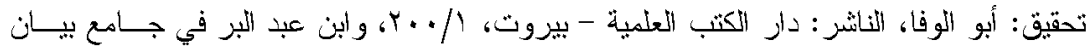

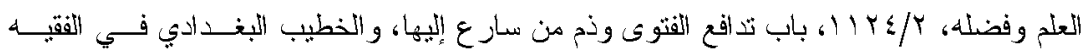

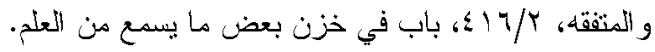

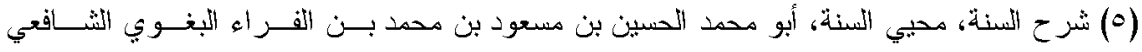

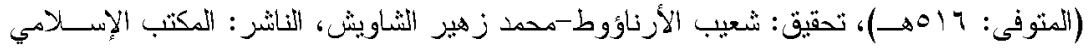

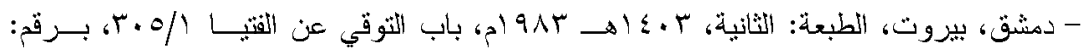

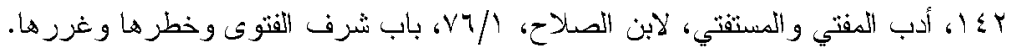


مجلة كلية الدراسات الإسلامية والعربية للبنات بدمنهور العدد الخامس الجزء التاسع •r+rم

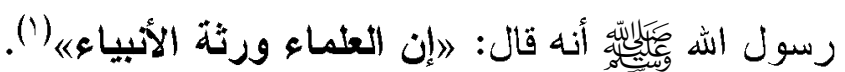

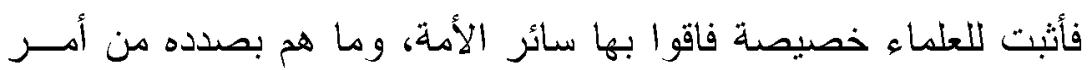

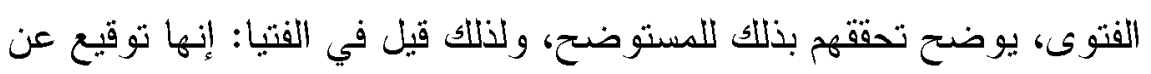

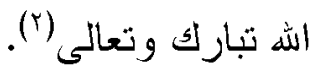
المسألة الثالثة: الفرق بين الفتوى والثئ والقضاء.

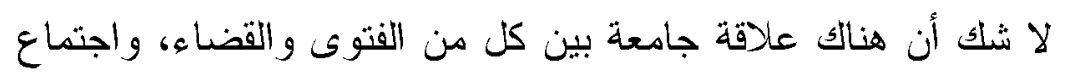

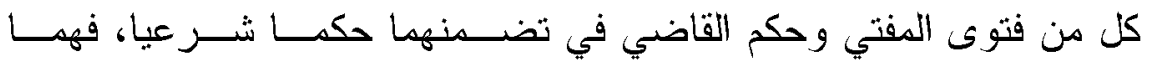

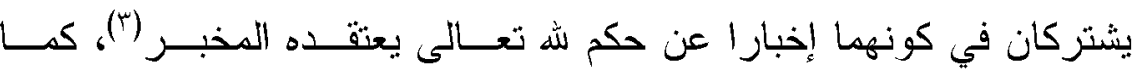

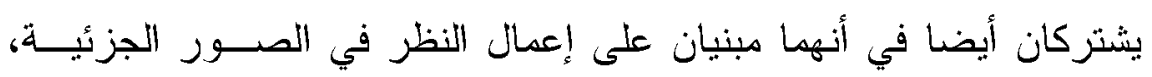

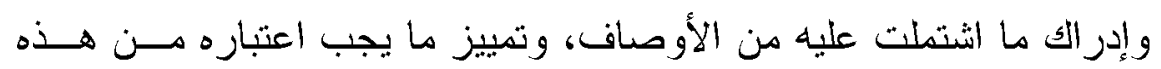

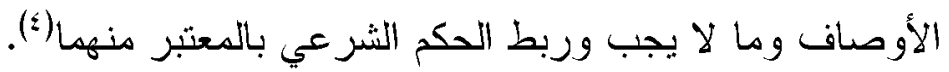

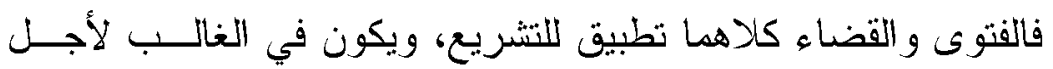

المساو اة بين الحكم التشريعي و الحكم التطبيقي (0).

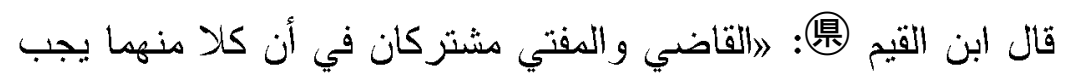
عليه إظهار حكم الثرع في الو اقعةدها").

(1) النهتج الأقوى في أركان الفتوق، در اسة فقهية مقارنة لأحكام وآداب الفتوق و المفتـي و المســنفتي،

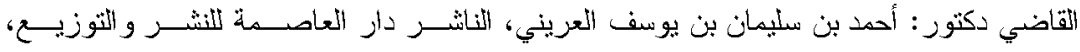

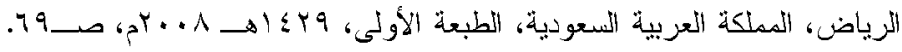

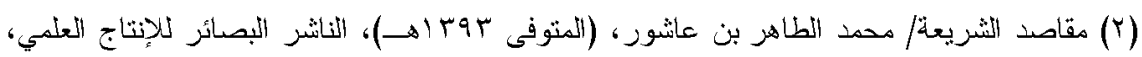

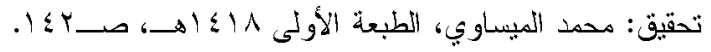

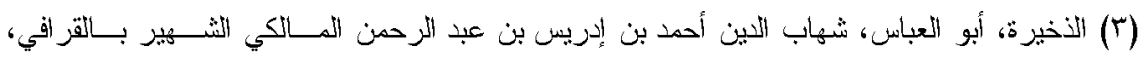

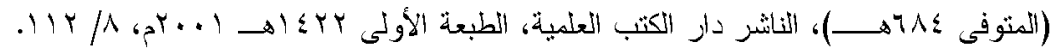

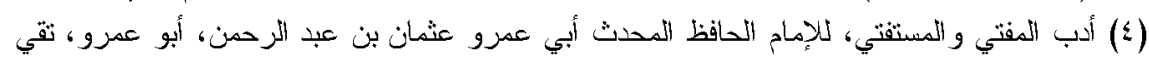

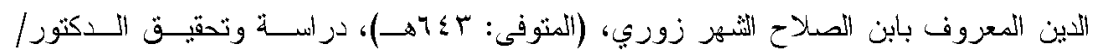

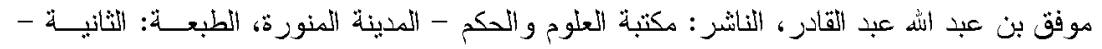

$$
\begin{aligned}
& \text {. VI } \\
& \text { (0) المصدر السابق. }
\end{aligned}
$$

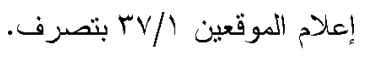


و الفتوى و القضاء يعتددان في إظهار الأحكام على الأدلة الثـــرعية،

وأنها تتتضض أحكامها إذا خالفت نصا قاطعا أو إجماعا هنعقاء (1).

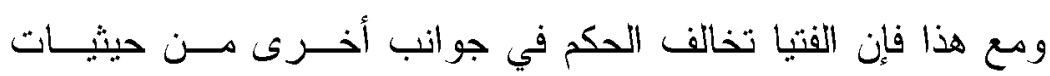

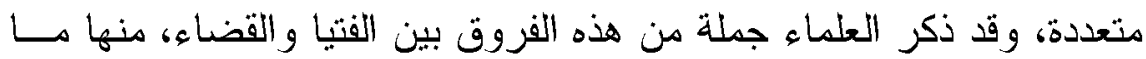
يرجع إلى فرق في الحقيقة بينهما، ومنا ما يعود لتو ابع كل منهما، ومنها ماهـ يقع في دجالاتها وسنذكر إجمالا أهم الفروق:

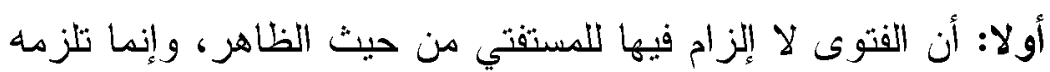
ديانة إذا اعتقد صحتها، كما تلزم المستفتي إذا كان مقلدا لمذهب المفتي ورلا

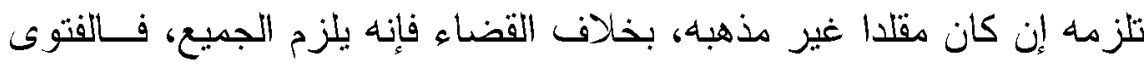

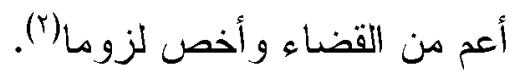

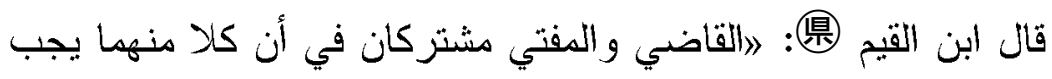

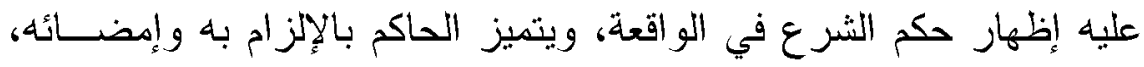

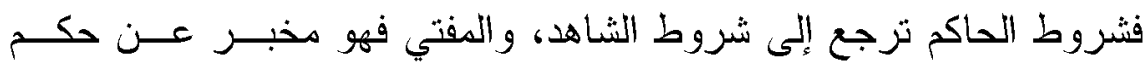

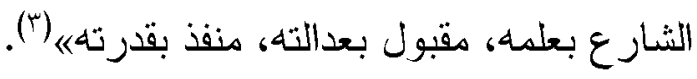

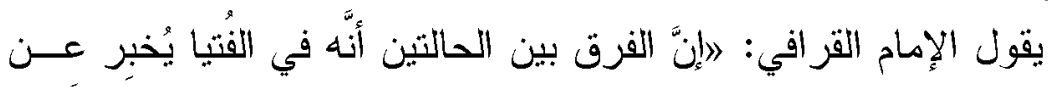

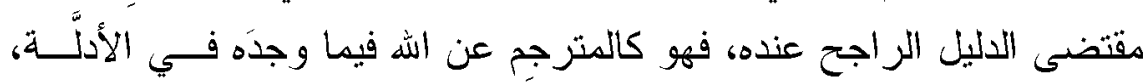

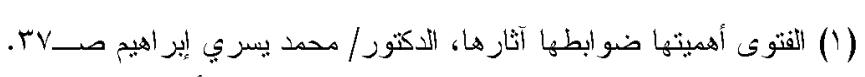

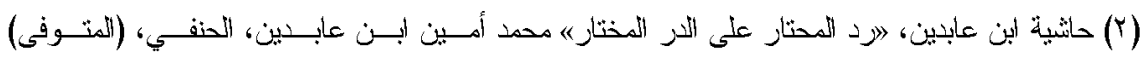

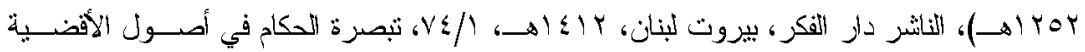

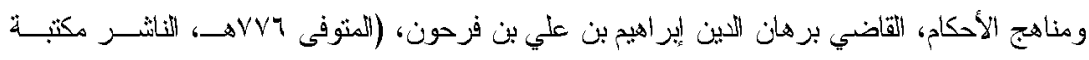

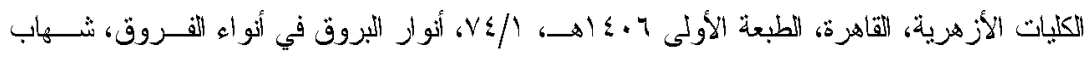

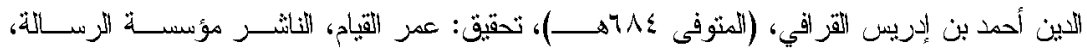

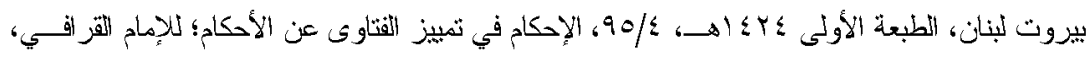

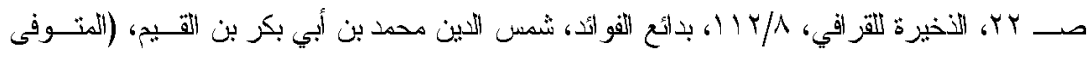

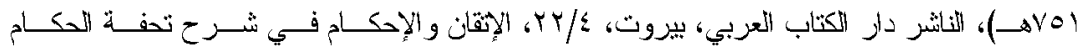

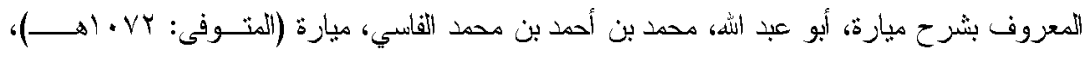

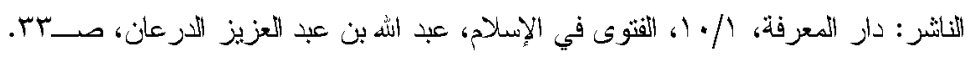


مجلة كلية الدراسات الإسلامية والعربية للبنات بدمنهور العدد الخامس الجزء التاسع •r+rم

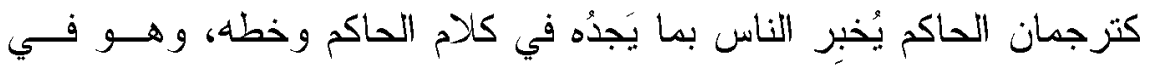

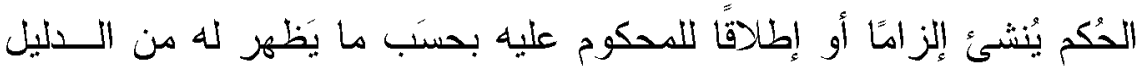

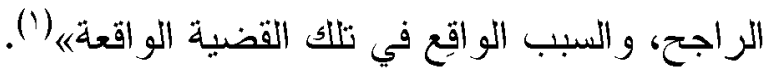

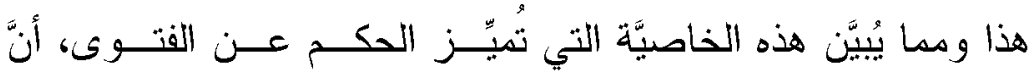

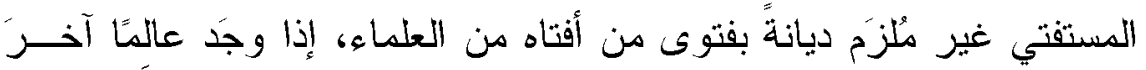

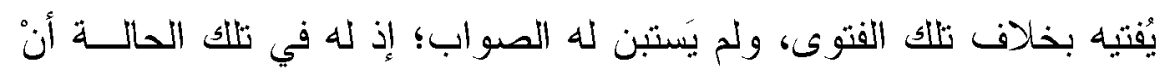

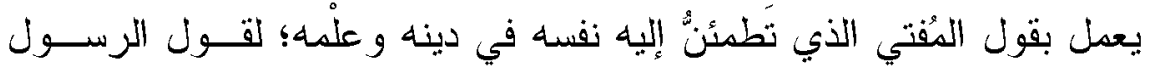

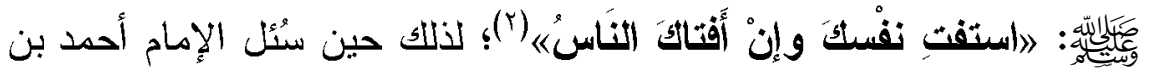
حنبل عن دسألة في الطلاق، قال: 》إنْ فعل حنَث، فقال السائل: إنْ أفتــاني

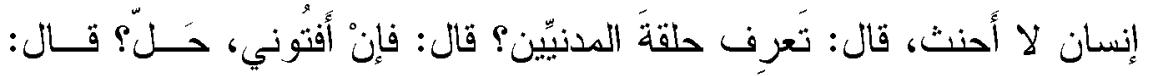

نعم «" (ז)

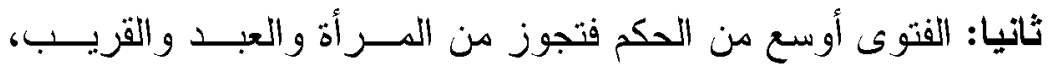

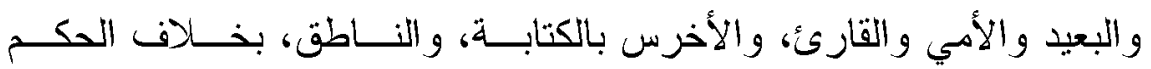
والقضاء فلا يجوز هن جميع هؤ لاء بل من بعضهم (؛).

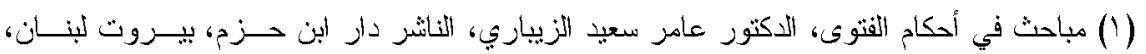

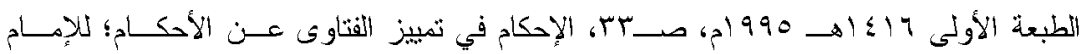

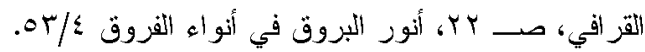

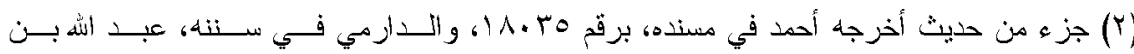

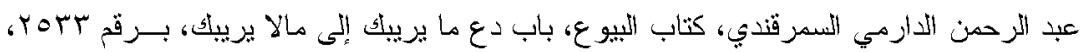

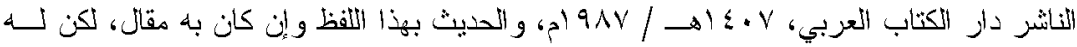

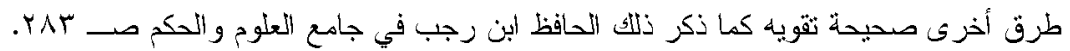

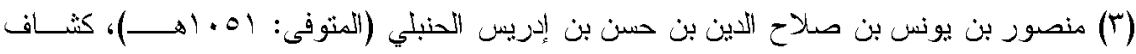

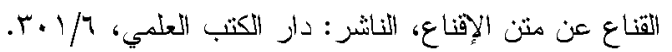

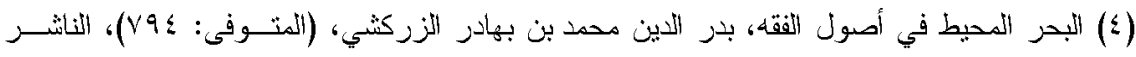

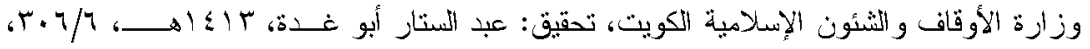

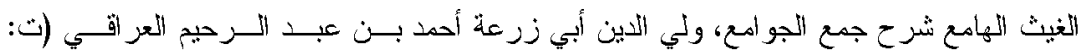

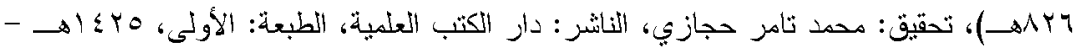

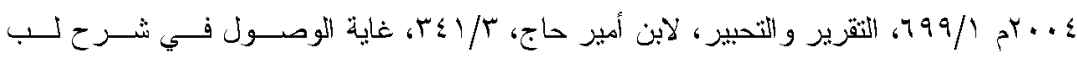


جاء في البحر الرائق ('): لو لا يشترط فيه بعد صحة العقيدة علم الكــلام ولا تفاريع الفقه و لا الذكورة والحرية ولا العدالة فللفاسق الاجتهاد ليعكل بنفسه، بهده

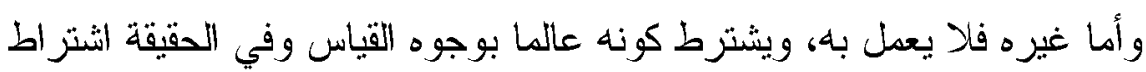

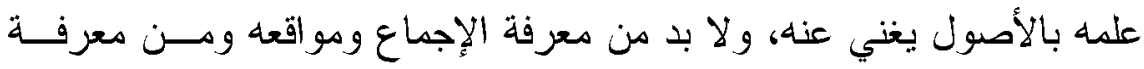

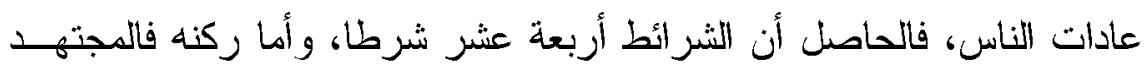
وهو ما قدمناه و المجتهد فيه وهو حكمّ شرعي ظني عليه لليلهِ.

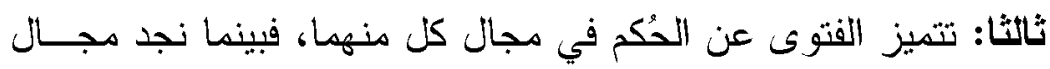

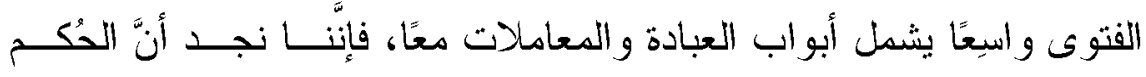
القضاء لا يجوز أن يكون في أبواب العبادات، فلا يدخلُ تحت القضاء الحكم

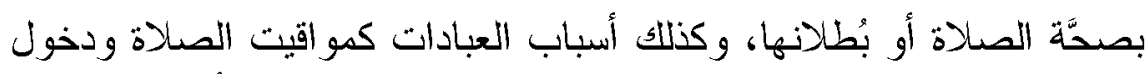

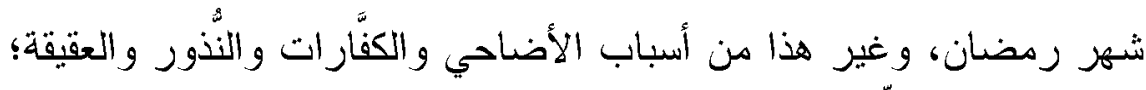

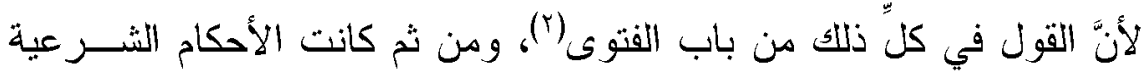

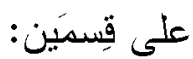

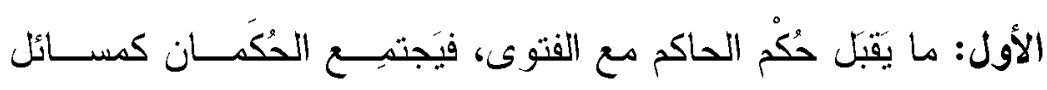

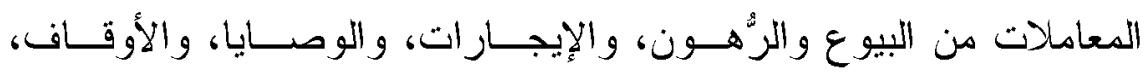
و الزواج، و الطلاق.

الثاني: ما لا يقبل إلا القتـوى؛ كالعبــادات وأســبابها، وشــروطها

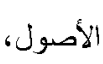

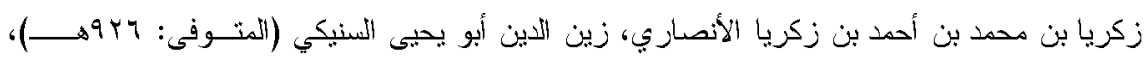

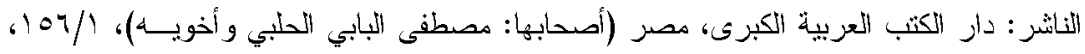

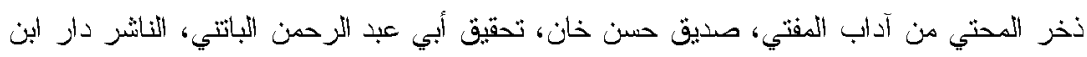

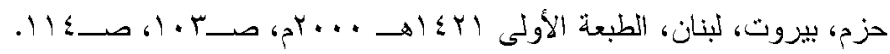

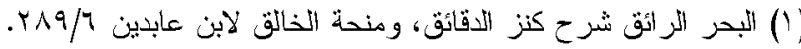

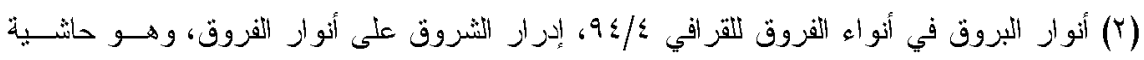

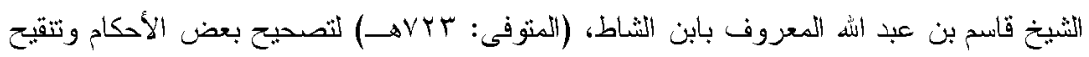

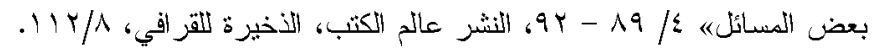


مجلة كلية الدراسات الإسلامية والعربية للبنات بدمنهور العدد الخامس الجزء التاسع •r+rم

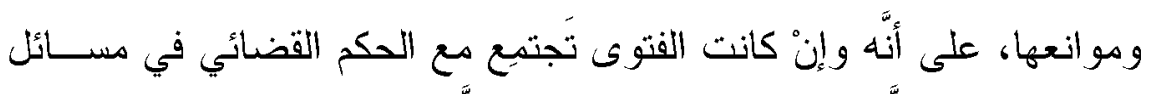

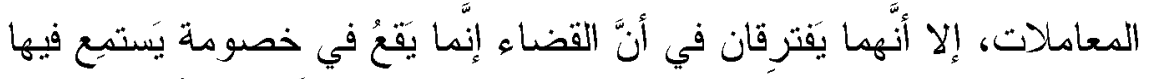

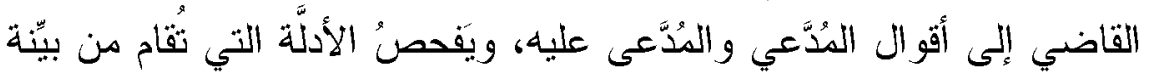

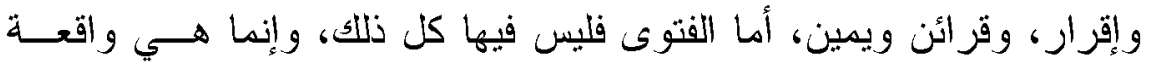

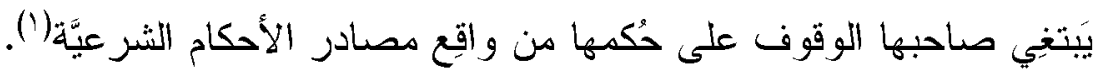

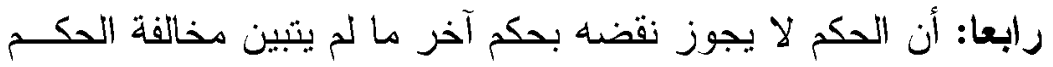

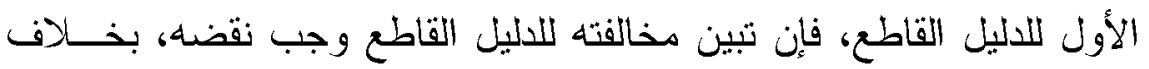

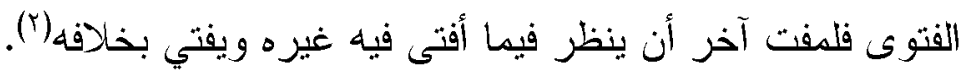

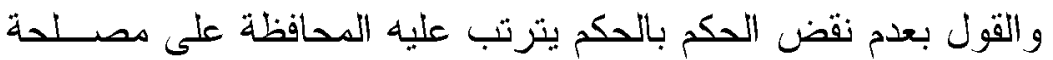
نصب الحكام و القضاة وهي الفصل في الخصومات لُّات. دثال عدم جواز نقض الحكم بالحكم، كما لو حكم بمنع القصاص فئي

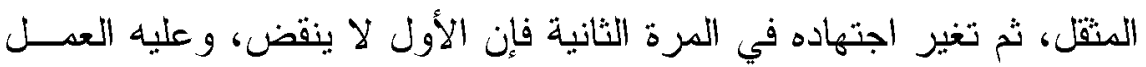

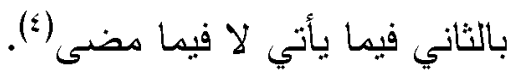
ومثال نقص الفتيا بالفتيا، كما لو أفنى الففتي بصحة نكاح البكر دون

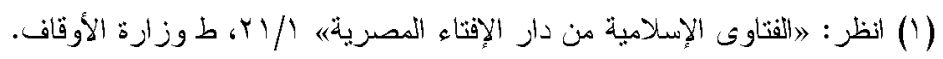

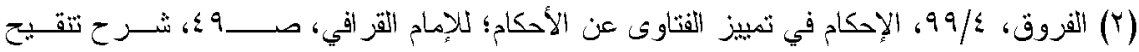

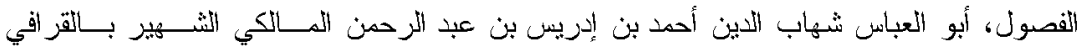

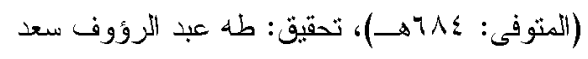

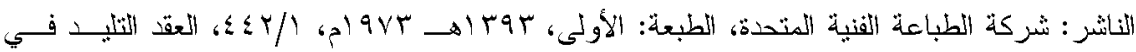

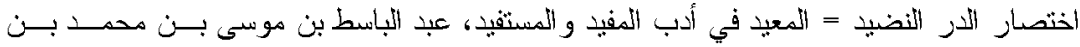

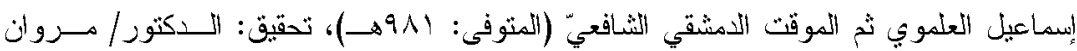

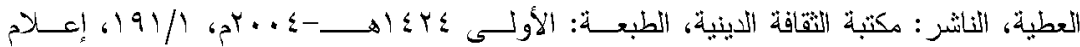

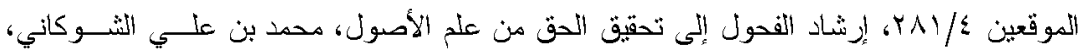

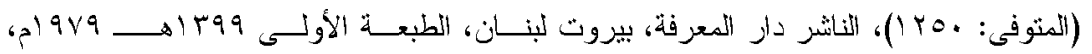

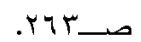

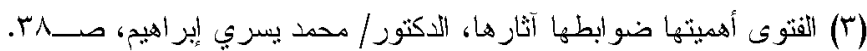

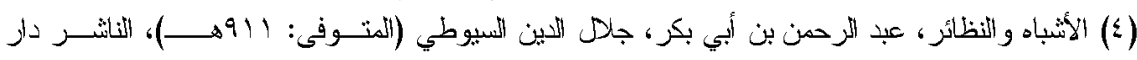

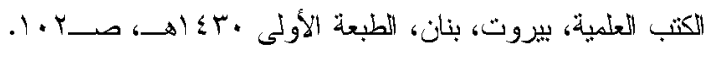


إذن وليها فتزوجت بناء على ذلك، ثم تغير اجتهاده في تلك الو اقعة، وأفتهى

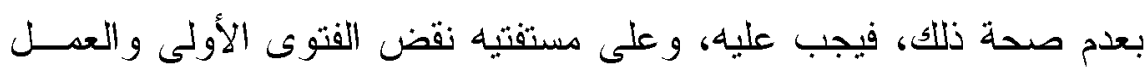

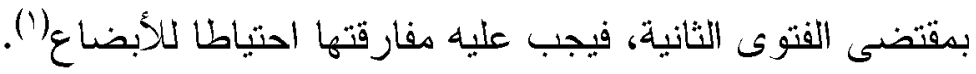
خامسا: الأحكام القضائية تكون في الو اجبات و المحرمات و المباحات،

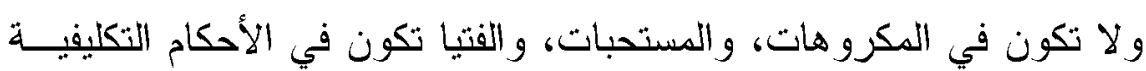
و الوضعية، كما تكون في الأحكام الاعتقادية(r). المسألة الر ابعة: شروط المئة المفتي.

اشترط الأصوليون شروطا في المفتي لا بد من تو افرها كي تقبل فتواه

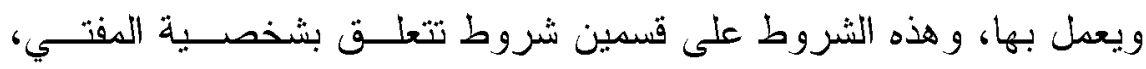
وشروط تتعلق بالإككانيات العلمية للدفتي:

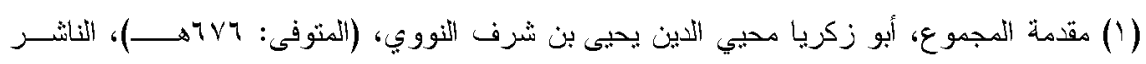

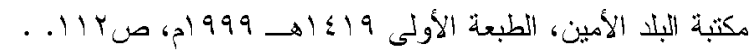

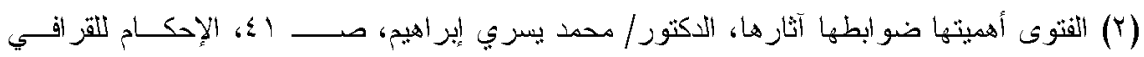

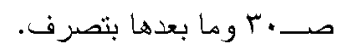


مجلة كلية الدراسات الإسلامية والعربية للبنات بدمنهور العدد الخامس الجزء التاسع •r+rم

\section{القسم الأول: الثروط التي تتعلق بشخصية المفتي، وهذه الثروط هي:}

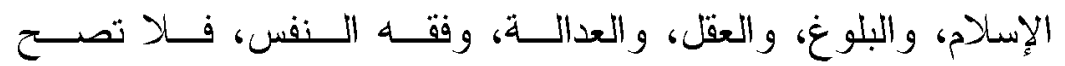

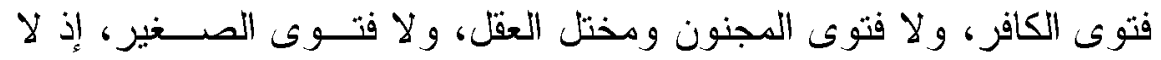
يقبل خبر هم (1).

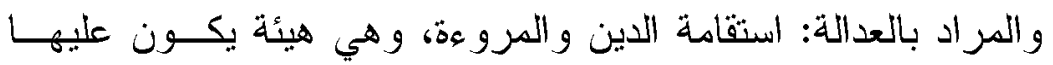

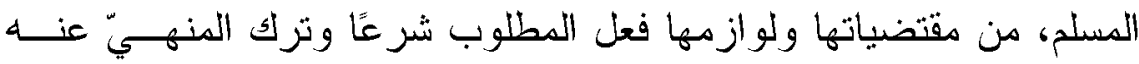

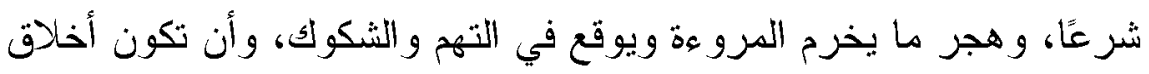

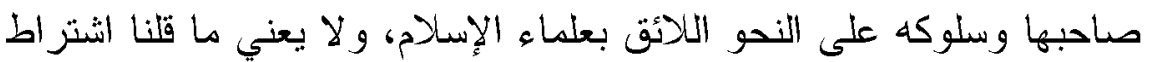

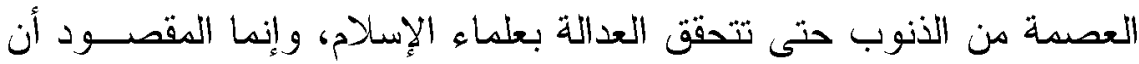

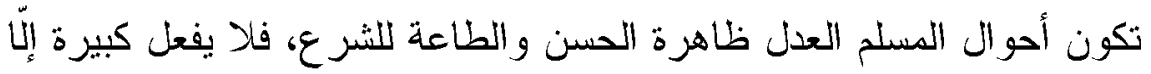

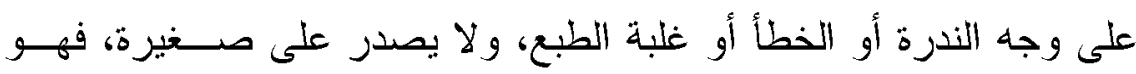

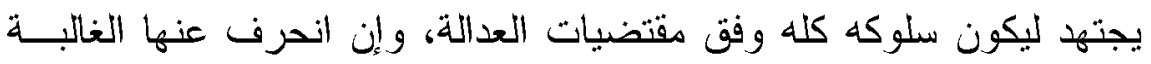

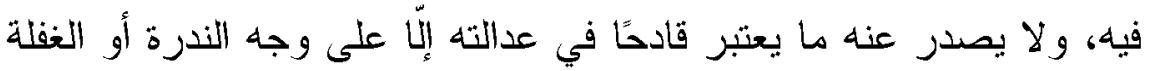

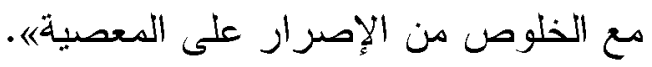

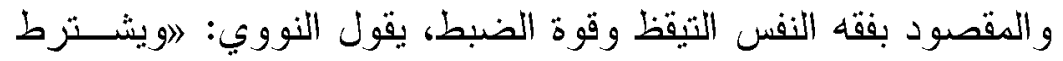

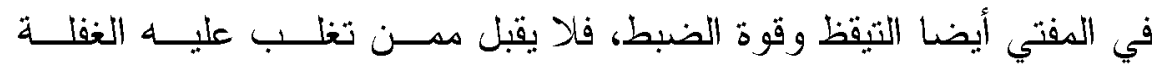

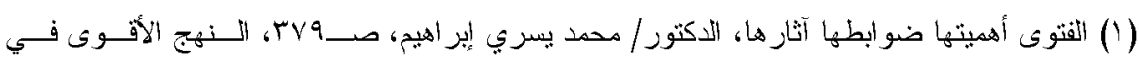

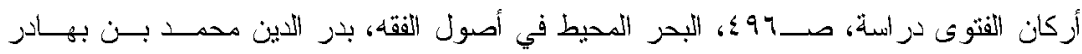

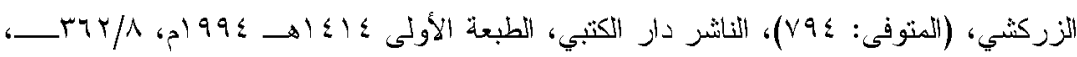

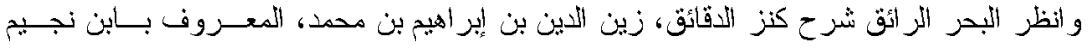

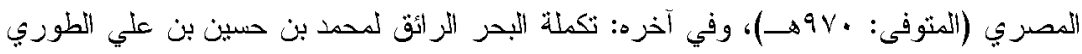

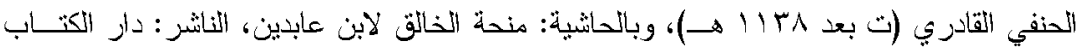

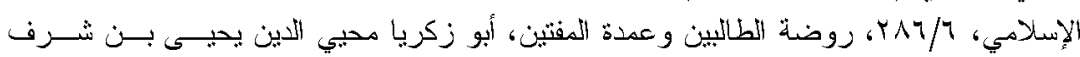

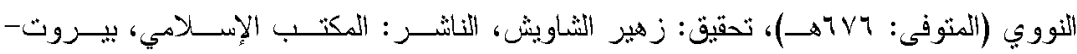

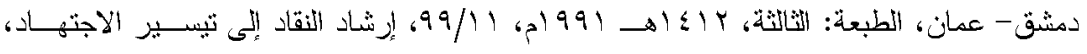

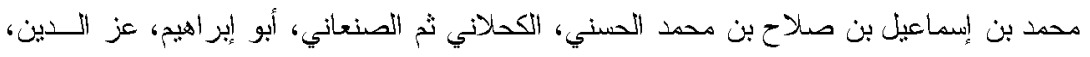

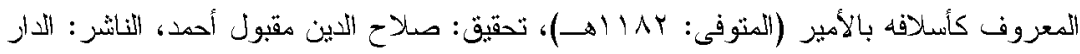

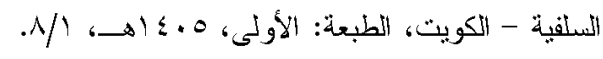


والسهو « ('). (1)

قال ابن الصلاح: أأما شروطه وصفاته: أن يكون مكلفًا مسلمًا، ثقـــة

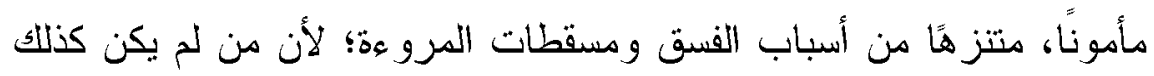

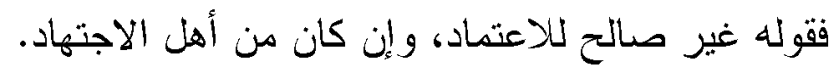

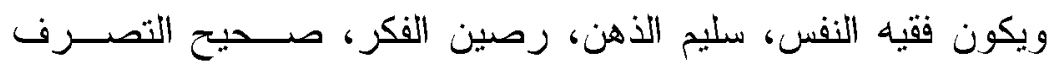

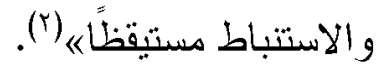
القسم الثاني: الثروط تثتق بالإمكانيات العلمية للمفتي، وهي على النحو الآتي:

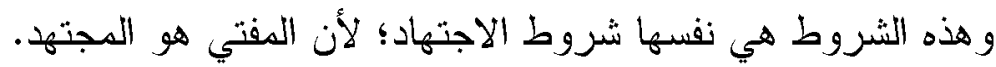

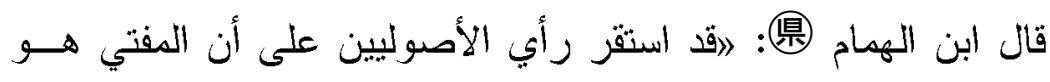

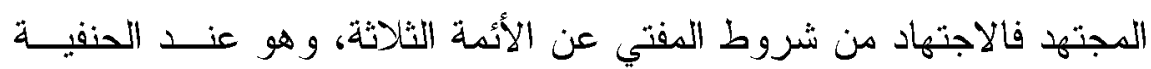
شرط أولية لا شرط صحة تسهيلا على الناسه" (ّ).

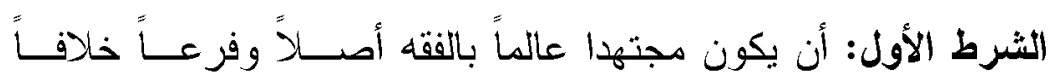

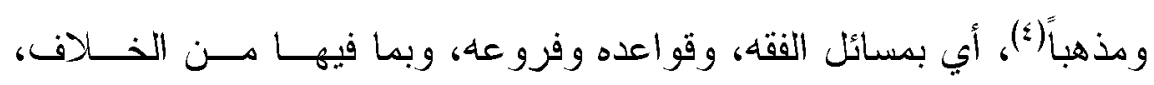

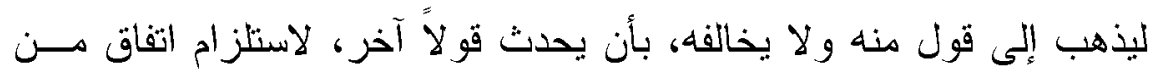
قبله بعدم ذهابهج إليه على نفيه (م) ولانه

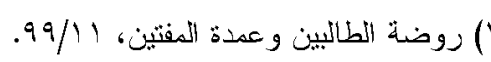

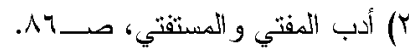

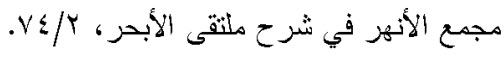

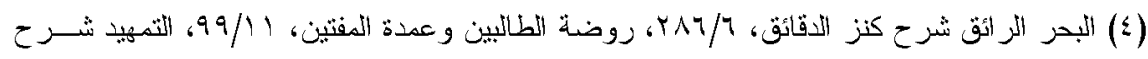

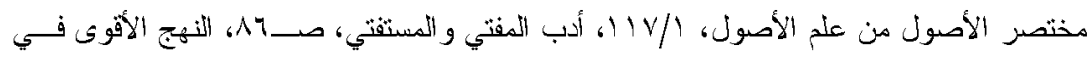

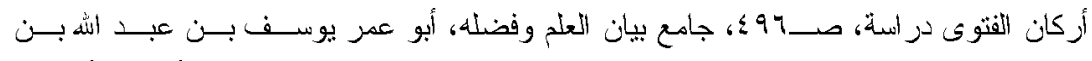

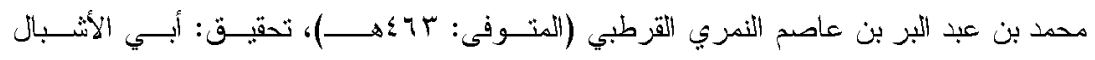

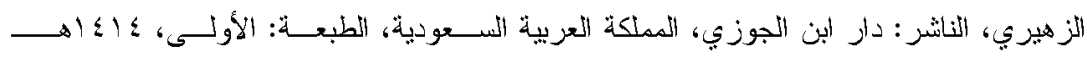

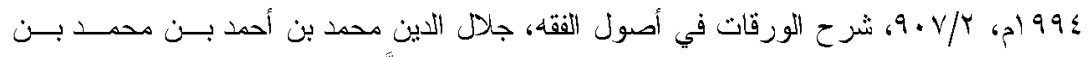

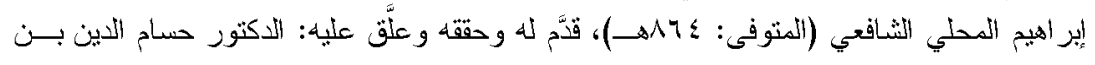

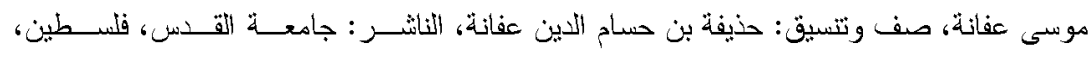

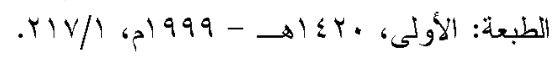

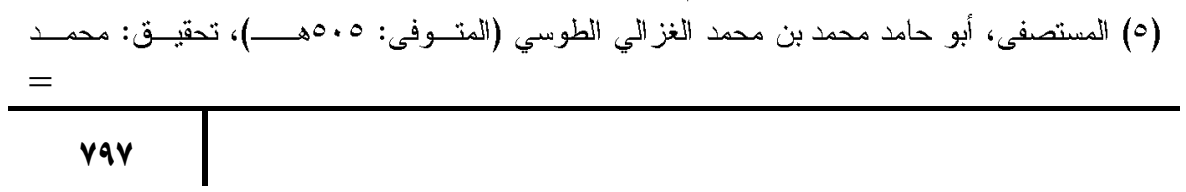


مجلة كلية الدراسات الإسلامية والعربية للبنات بدمنهور العدد الخامس الجزه التاسع •r+rم

الثرط الثاني: أن يكون عالما بكتــاب الله تعــالى، عالمـــا بالناســخ

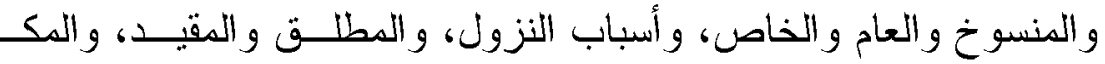

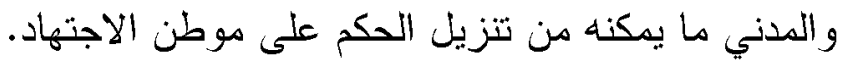

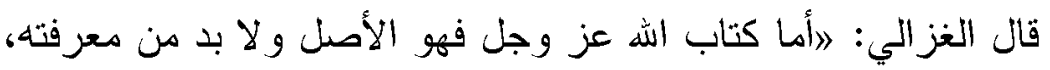

ولنخفف عنه أدرين:

أحدهما: أنه لا يشترط معرفة جميع الكتاب بل ما تتعلق به الأحكـام

منه وهو مقدار خمسمائة آيةٍ.

الثاني: لا يشترط حفظها عن ظهر قلبه بل أن يكون عالما بمواضهوها

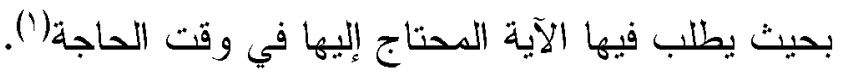

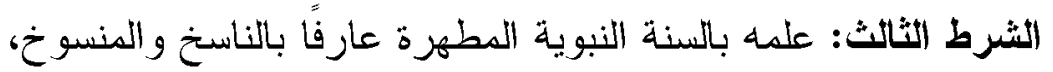

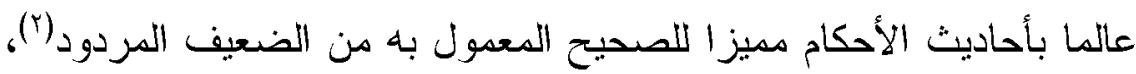

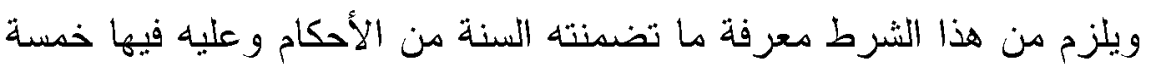

شروط.

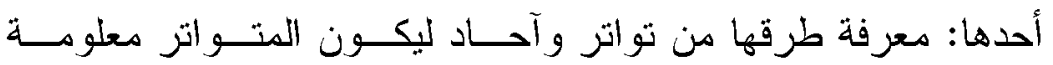

والآحاد مظنونه.

والثاني: دعرفة صحة طرق الآحاد ودعرفة رواتها ليعل بالصــيح

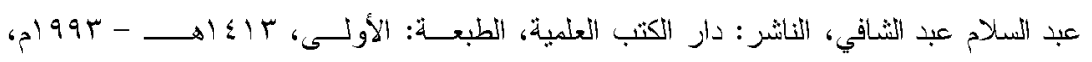

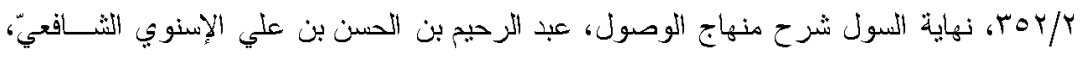

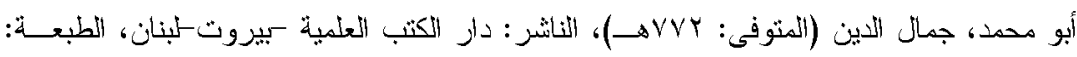

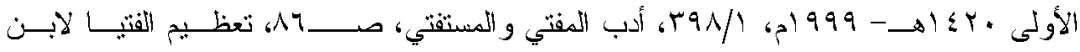

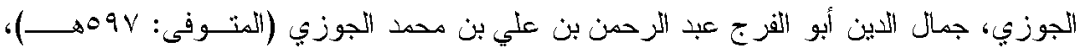

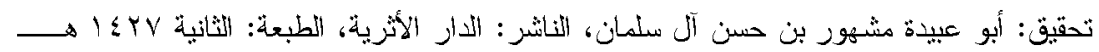

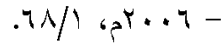

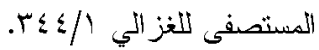

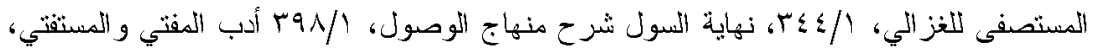

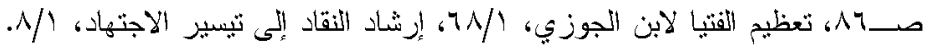


منه ويعدل عما لا يصح منه.

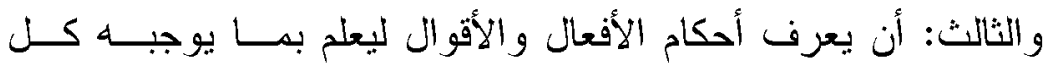

$$
\text { واحد دنهما. }
$$

و الر ابع: أن يحفظ معاني ما انتفى الاحتمال عنه ويحفظ ألفاظ ما دخله

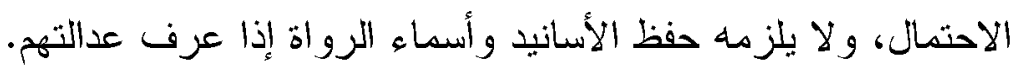

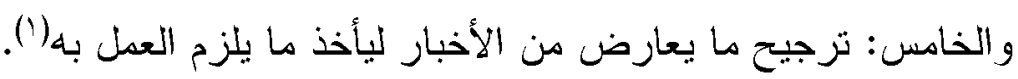

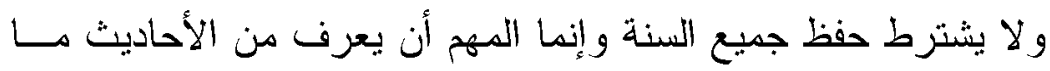
يتعلق بالأحكام ولا يلزم حفظها عن ظهر قلبه، فيكفي أن يكون همارسا لها،

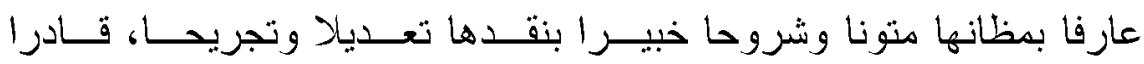

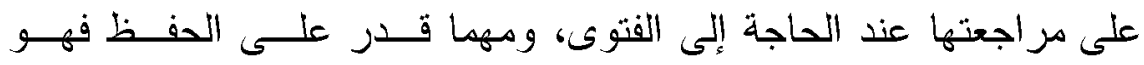

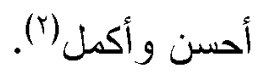

الثرط الرابع: أن يكون عارفا بمسائل الإجماع وما ينعقد به الإجماع

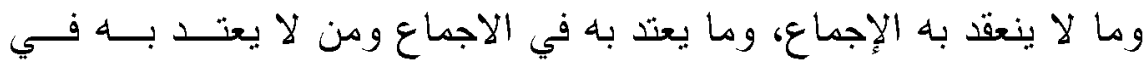

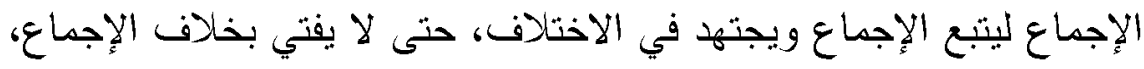

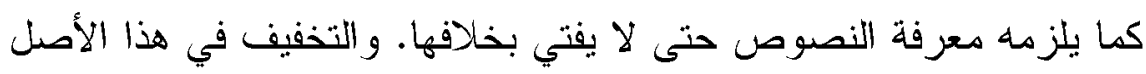

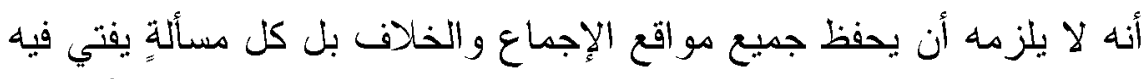
فينغغي أن يعلم أن فتو اه ليس مخالفا للإجماع؛ إما بأن يعلم أنه دو افق هذه هذهبا

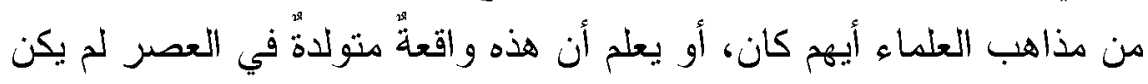

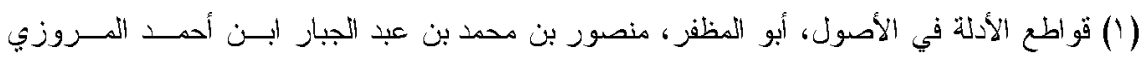

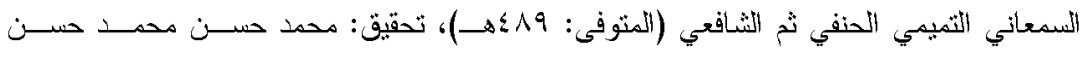

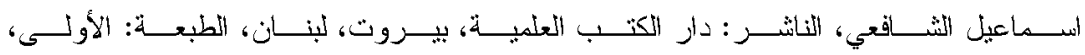
$. r+Y / r$ ، $1999 /-1 \leq 11$

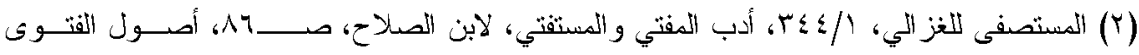

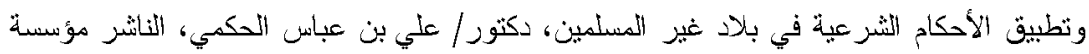

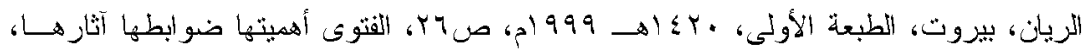

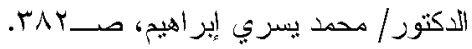


مجلة كلية الدراسات الإسلامية والعربية للبنات بدمنهور العدد الخامس الجزء التاسع •r+rم

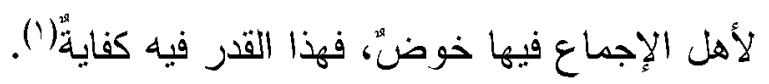

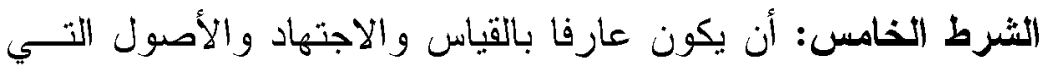

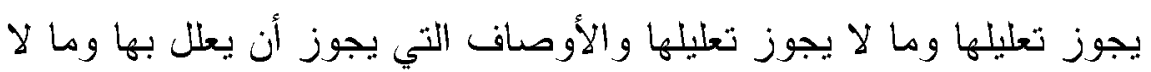

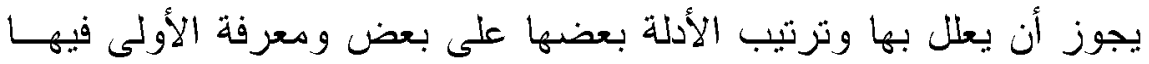

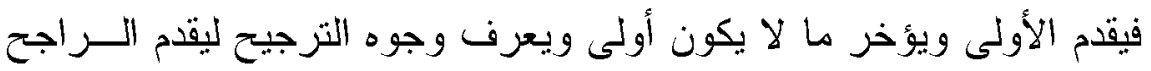

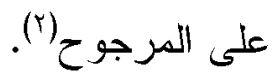
الثرط السادس: وأن يكون كامل الآلة في الاجتهاد عارفاً بما يحتاج

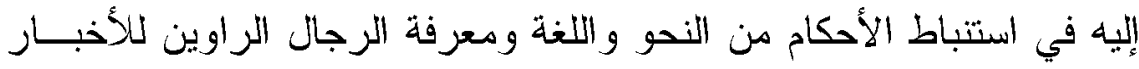

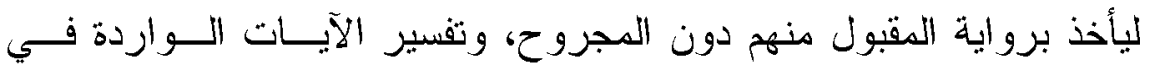

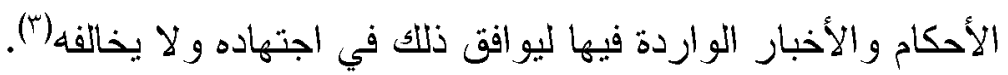

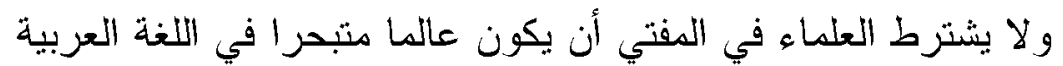

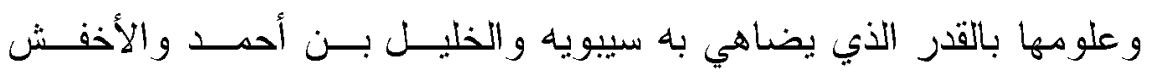

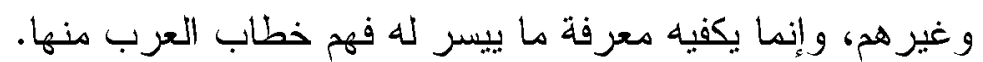

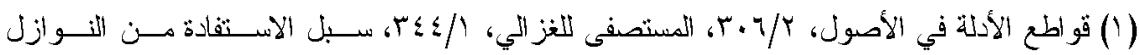

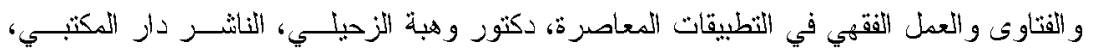

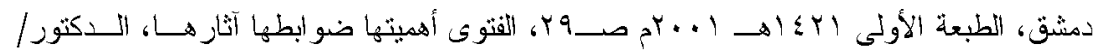

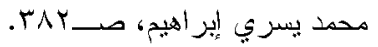

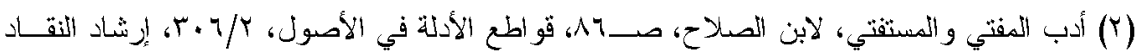

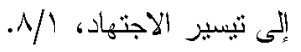

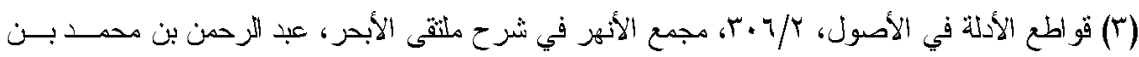

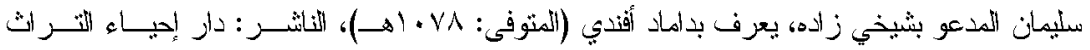

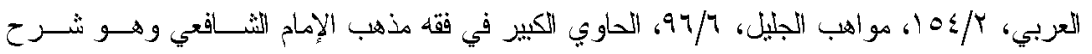

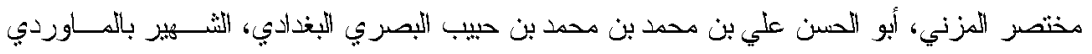

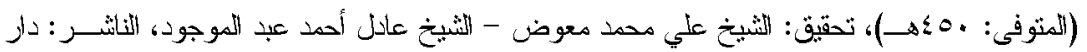

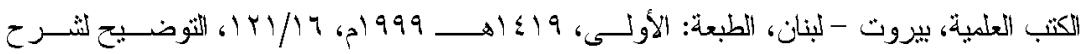

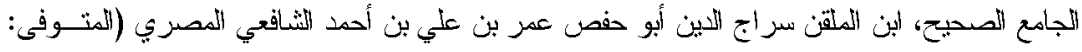

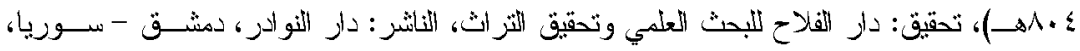

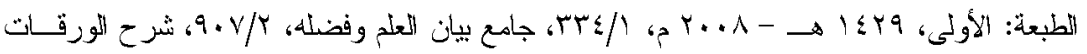

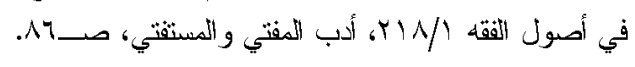


يقول إمام الحرمين: 》ادعرفة اللغة والنحو على وجهِ يتيسر له به فهم

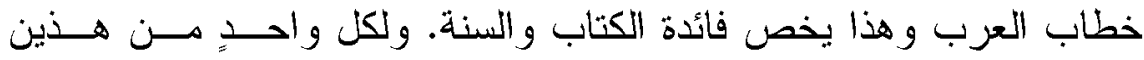

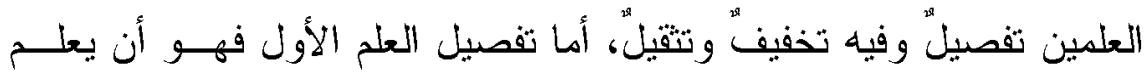

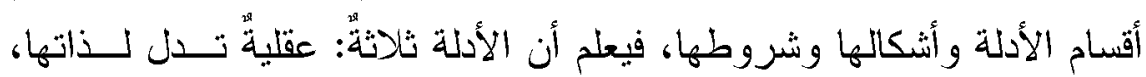
وشر عيةٌ صارت أدلة بوضع الشرع، ووضعيةٌ وهي العبار ات اللغوية.

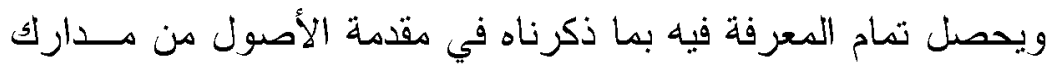

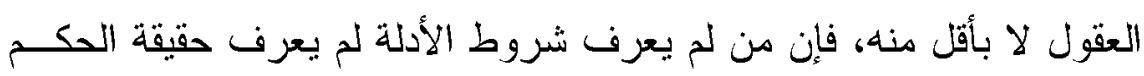

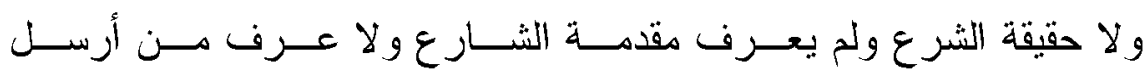

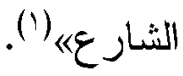

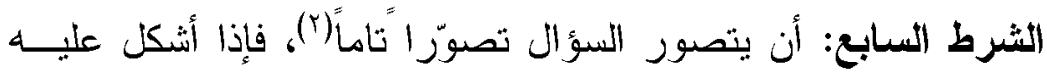

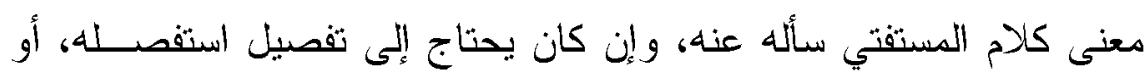

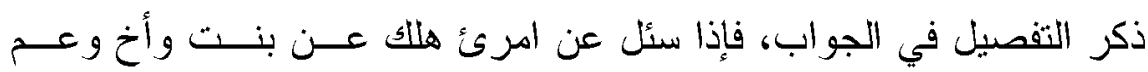

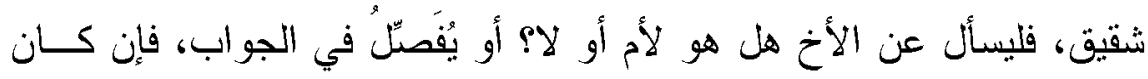

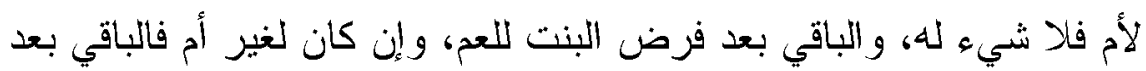

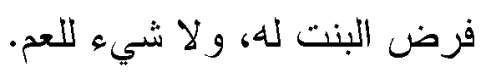

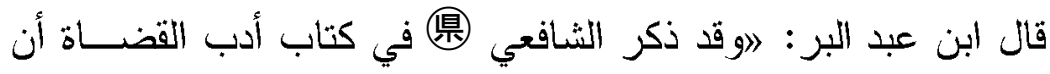

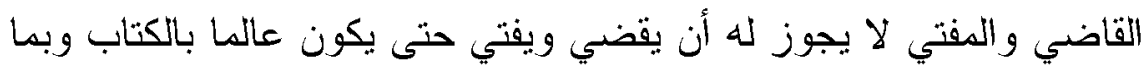

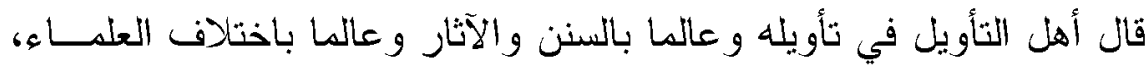

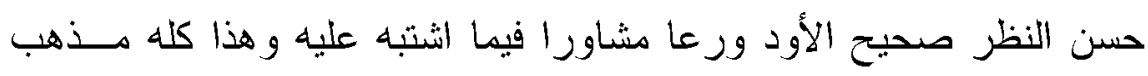
مالك، وسائر فقهاء المسلمين في كل دصر يشترطون أن القاضي و المفتي لا

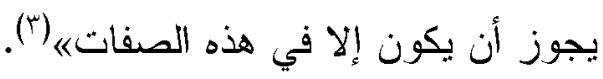

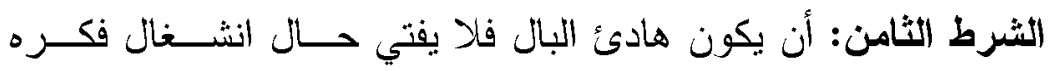


مجلة كلية الدراسات الإسلامية والعربية للبنات بدمنهور العدد الخامس الجزء التاسع •r+rم

بغضب أو هم أو ملل أو غيرها، كالجوع، أو العطش، أو الحزن، أو الفرح

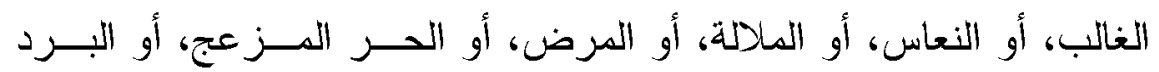

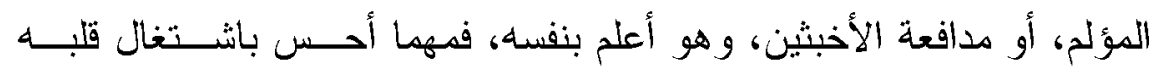

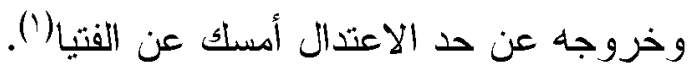

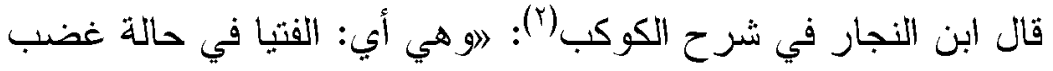
ونحوه كثدة جوع، وشدة عطش، وهم، ووجع، وبرد مؤلم، وحر هـزعزي،

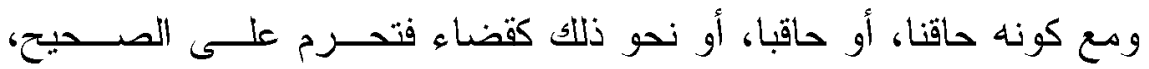

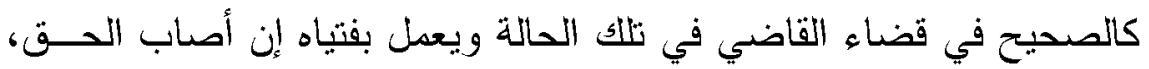

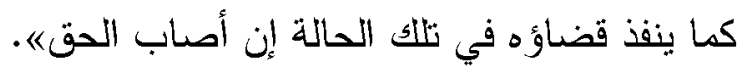
الثرط التاسع: أن يكون ثقة مأمونا متسما بالوسطية والاعتدال التهال وعدم التثدد أو التساهل في أمور الدين(بّ).

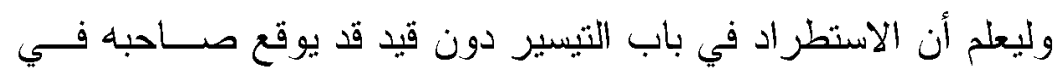

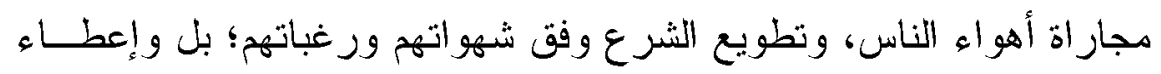

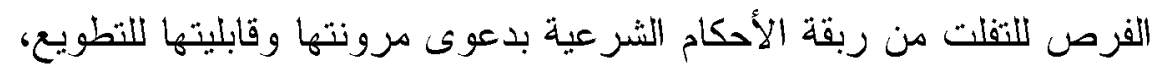

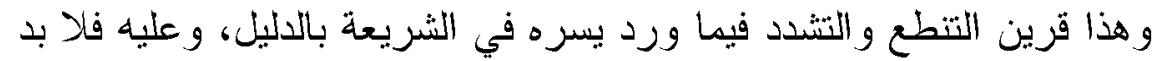

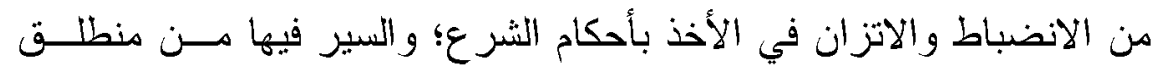

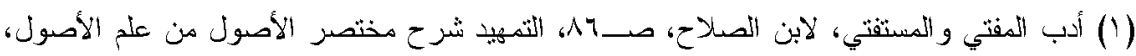

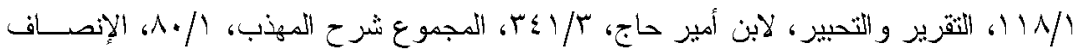

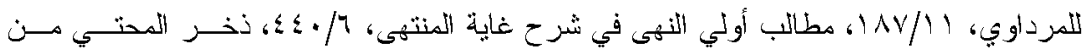

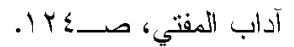

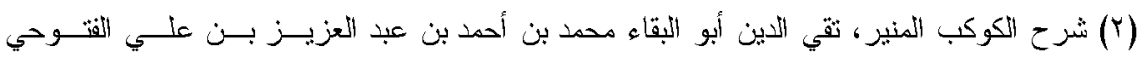

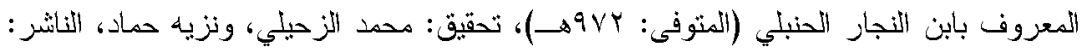

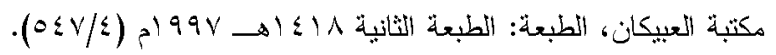

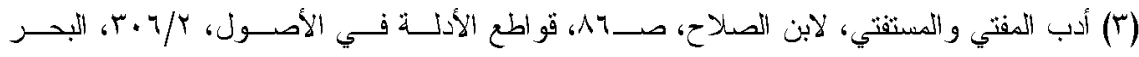

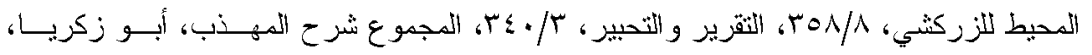

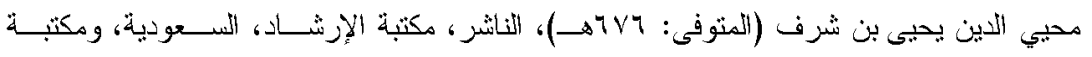

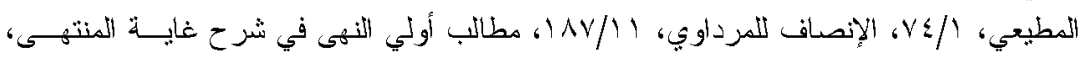


القو اعد الثرعية والنصوص المرعية، وألا يكون متعصبا ليــذهب بعينــه، فالتعصب لمذهب وترك باقي المذاهب بداية الخطأ في الفتوى.

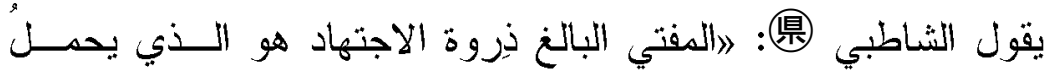

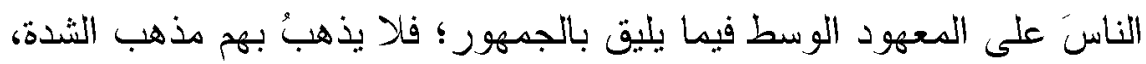

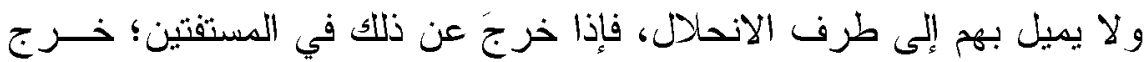

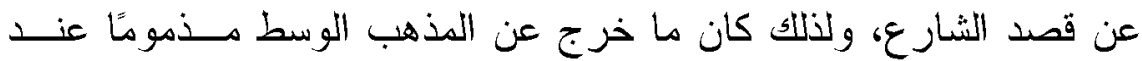
العلماء الر اسخينه (1)

الثرط العاثشر: أن يكون على علم بمقاصد الأحكام الثر عية، فينبغي

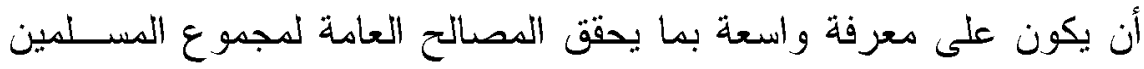

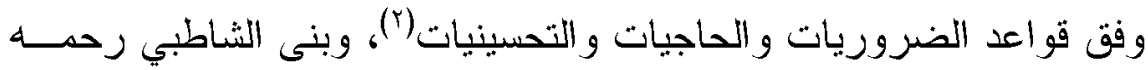
الله تعالى الاجتهاد في هذه الحالة على أصلين أساسيين:

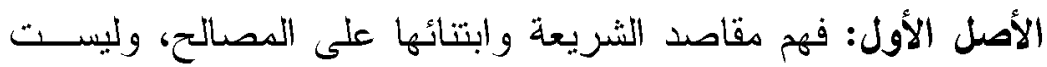

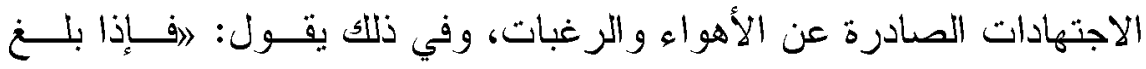
الإنسان مبلغا، فهم عن الثار ع فيه قصده في كل مسألة من مسائل الشريعة،

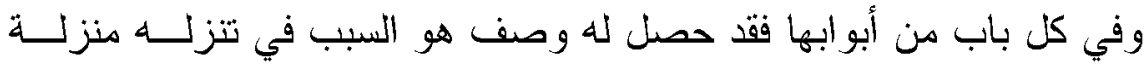

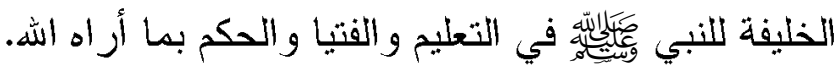
وأما الثاني: فهو كالخادم للأول؛ فإن التمكن من ذلك إنما هو بواسطة

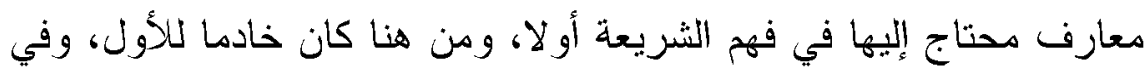

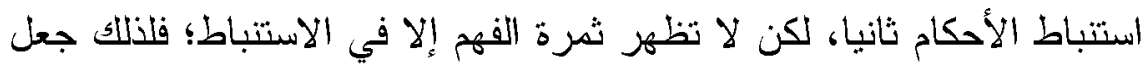
شرطا ثانيا، و إنما كان الأول هو السبب في بلوغ هذه المرنبة؛ لأنه المقصود والثاني وسيلةة (ّ).

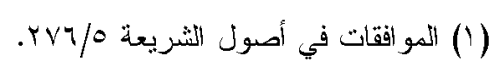

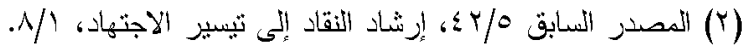

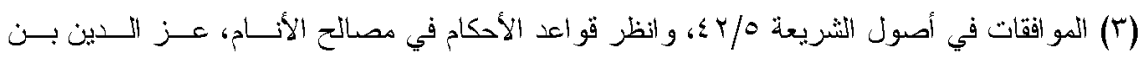

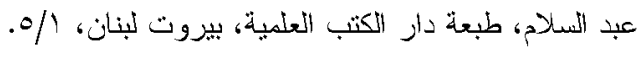


مجلة كلية الدراسات الإسلامية والعربية للبنات بدمنهور العدد الخامس الجزه التاسع •r+rم

الثرط الحادي عثر: شرط بعضهم أن يكون المفتي يقظــا لأمسـور الفتوى، احتراز ا عمن غلب عليه الغفلة والسهو، و هذا شرط لازم في زماننا،

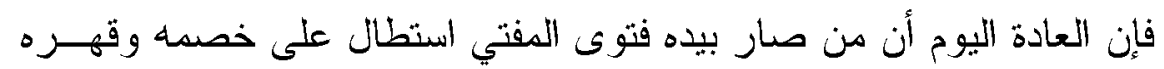

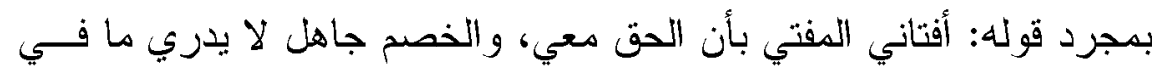
الفتوى، فلابد أن يكون المفتي مستيقظا يعلم حيل الناس ودسائسهر، فإذإ جاء ولهاء

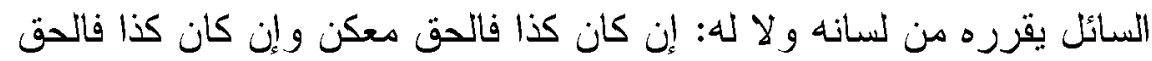

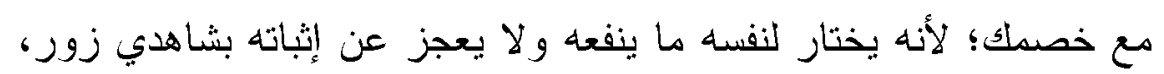

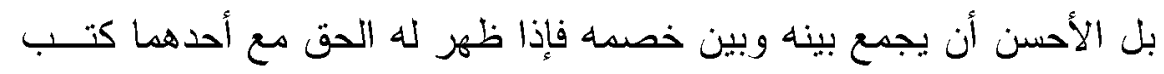

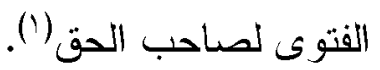

(1) المصباح في رسم المفتي ومناهج الإفتاء، صــ1 أه، و انظر : درر الحكام في شرح مجلة الأحكام،

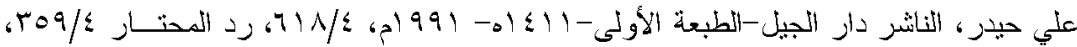

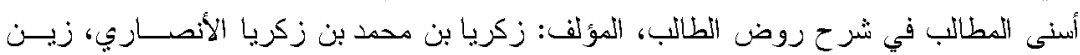

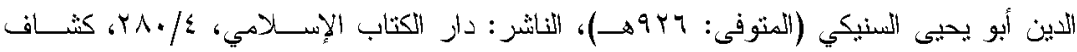

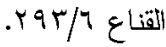




\section{المبحث الثاني: حكم الخطأ في الفتوى من حيث الإثم وعدمه}

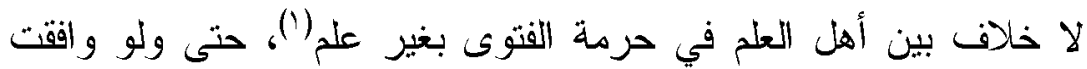

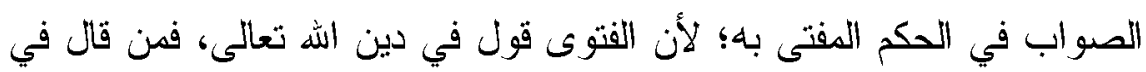

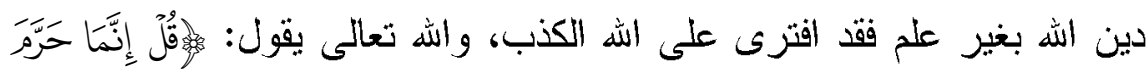

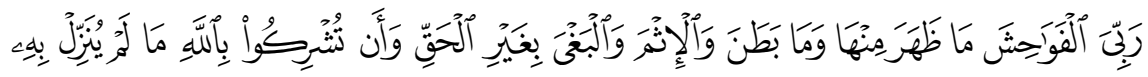

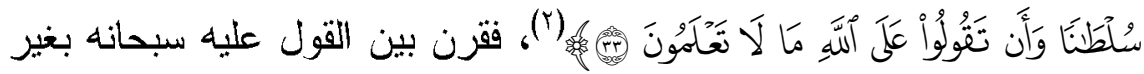

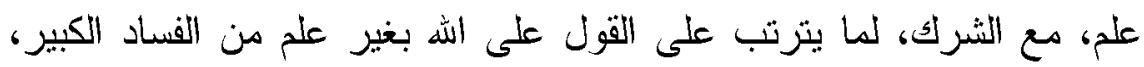

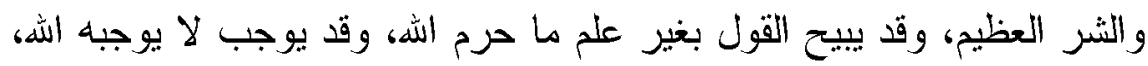
وقد يحرم دا أحل الله، وقد يوقع في شرور كثيرة، وقد أخبر الله تعالى في آية أخرى أن القول على الله بغير علم هن أمر الثيطان، فقال جل شأنه:

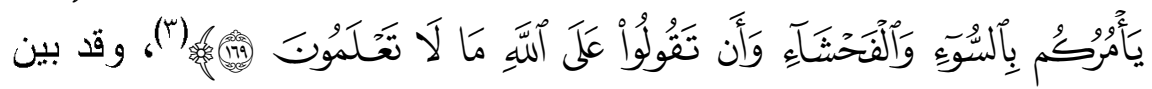

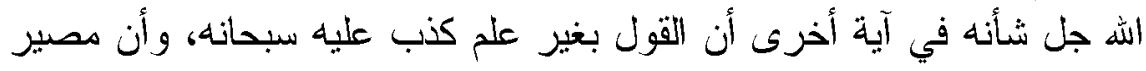

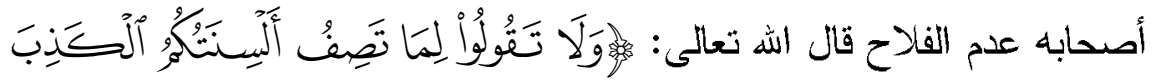

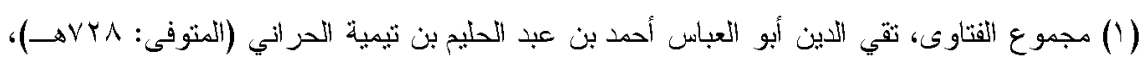

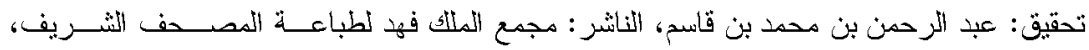

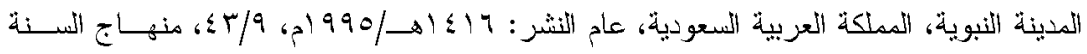

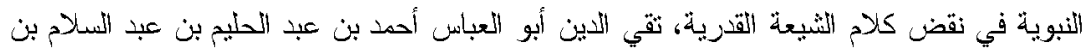

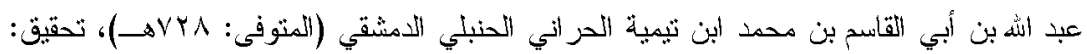

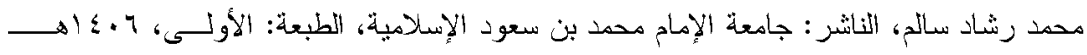

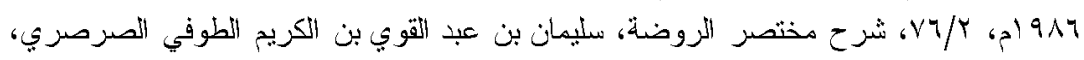

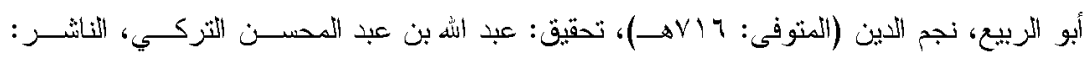

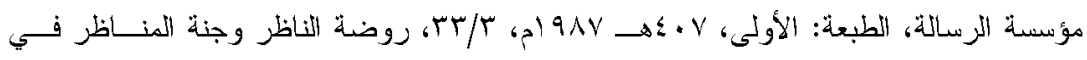

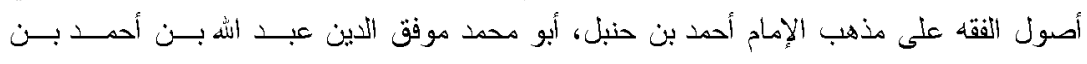

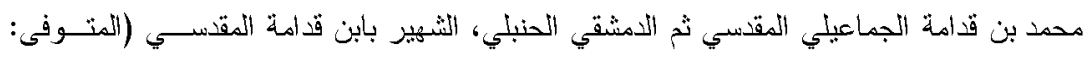

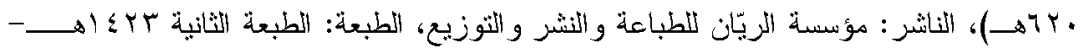

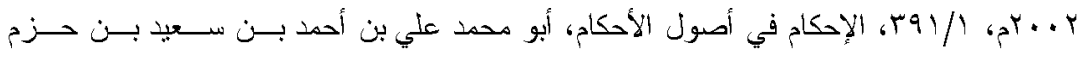

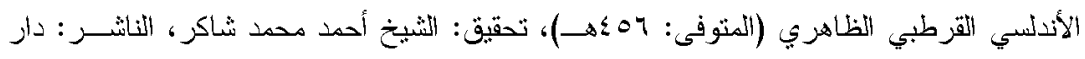


مجلة كلية الدراسات الإسلامية والعربية للبنات بدمنهور العدد الخامس الجزء التاسع •r+rم

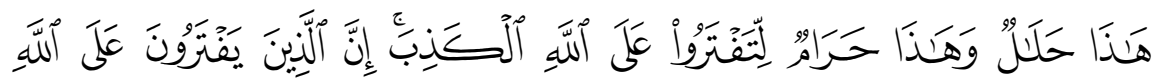

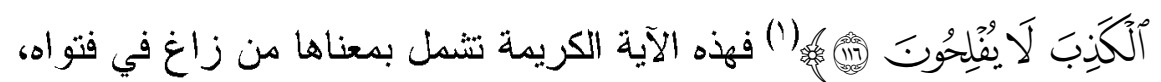

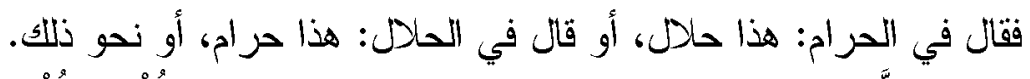

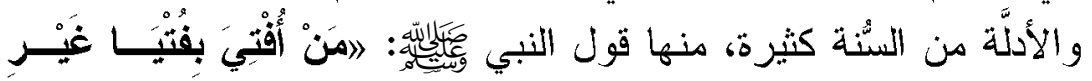

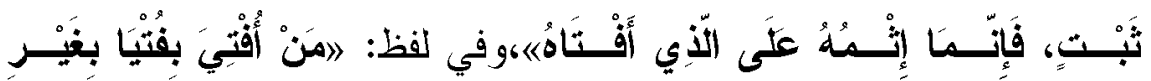

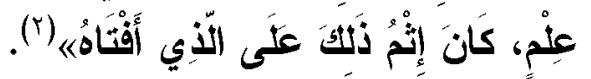

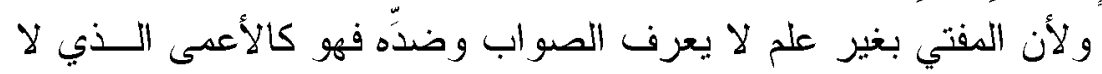

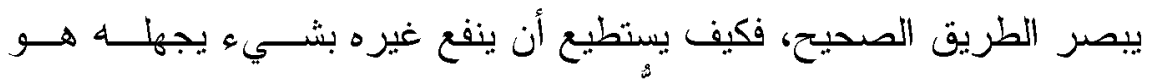

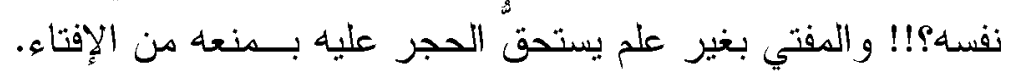

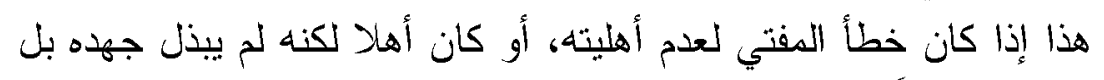

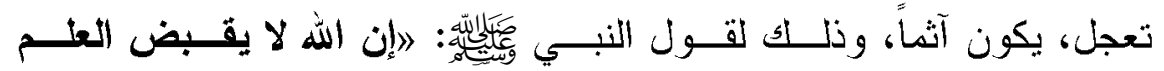

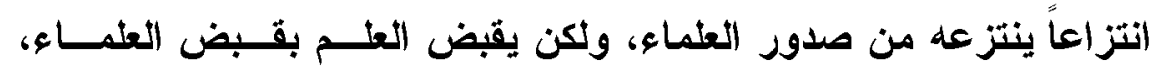

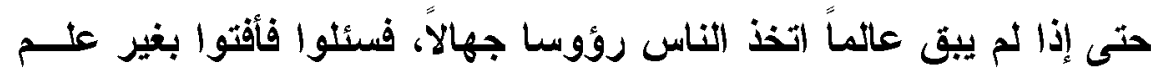

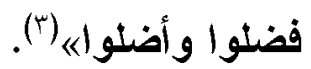

أما إن كان أهلا واجتهـ فأخطأ فلا إثخ عليه، بل له أجر اجتهاده قياسـاً

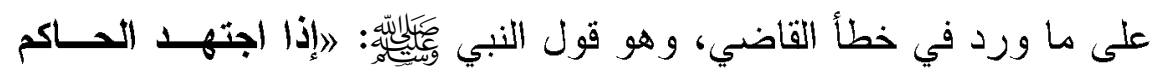

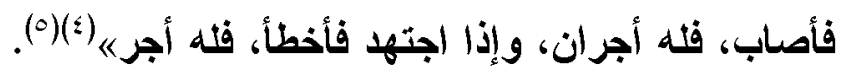

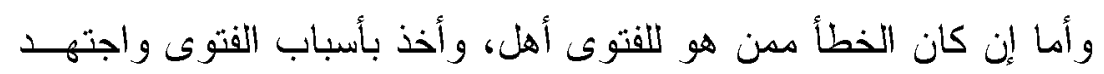

(1) سورة النحل آية بوابة (11) (Y) سيق تخريجه.

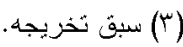

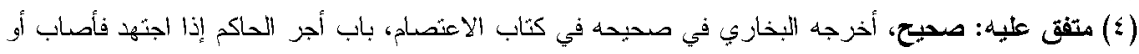

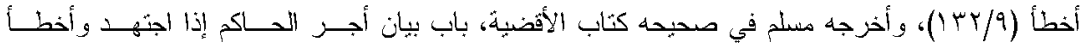

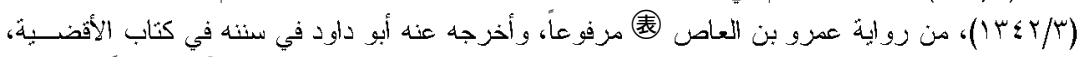

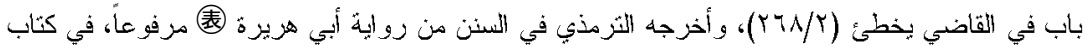

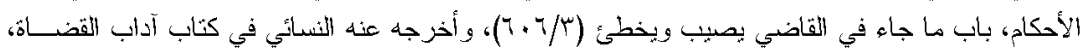




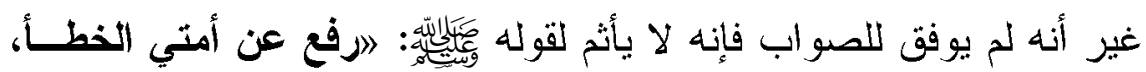

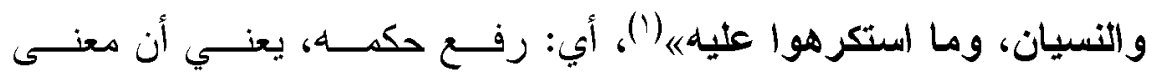

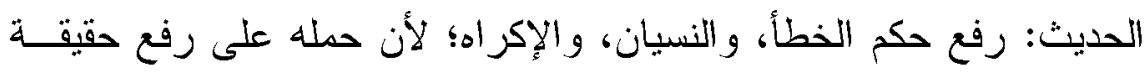

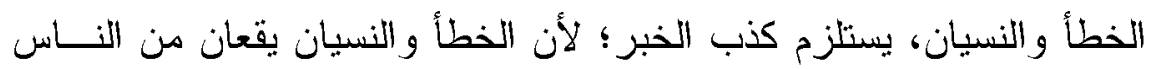
كثير ا، و الكذب في خبر المعصوم محال؛ فتعين حمله على رفع حكمه.

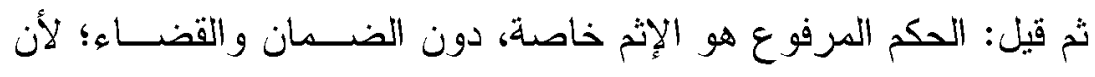

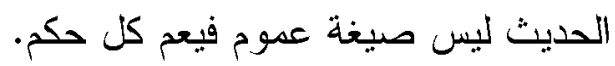
قلت: فيه نظر ؛ لأن تقدير الحديث: رفع مع عن أمني حكم الخطأ، واللام في

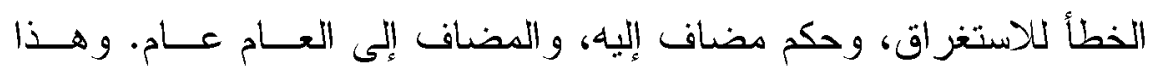

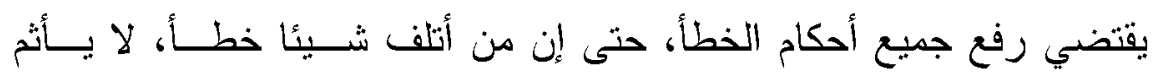

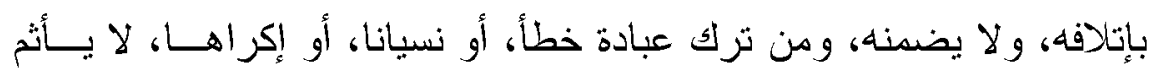

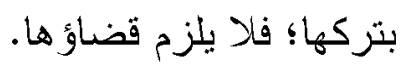

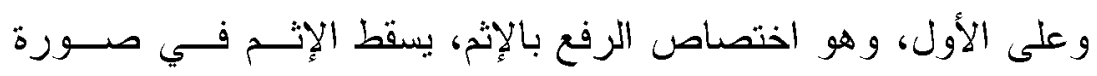

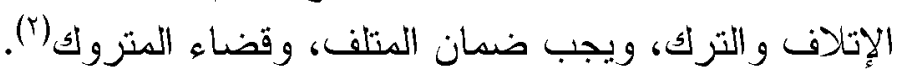

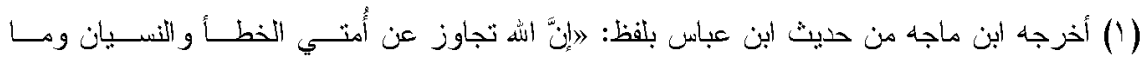

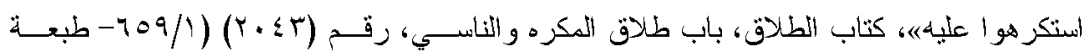

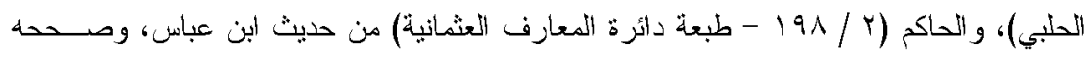

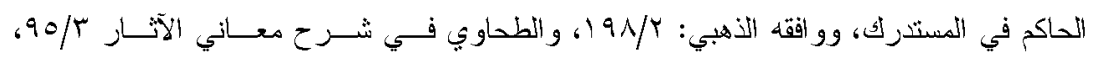

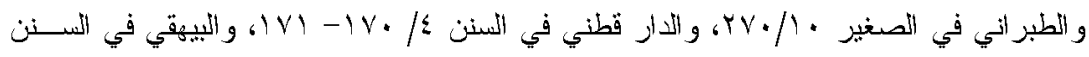

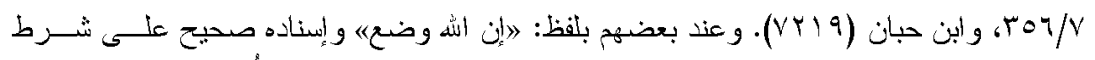

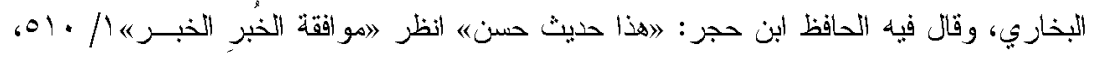

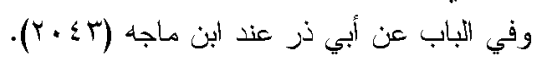

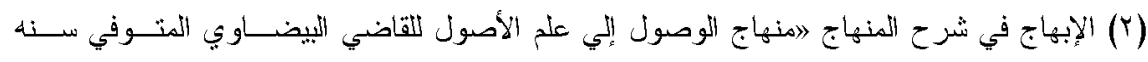

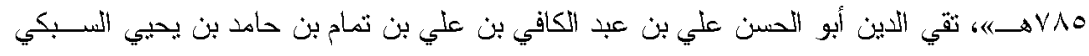

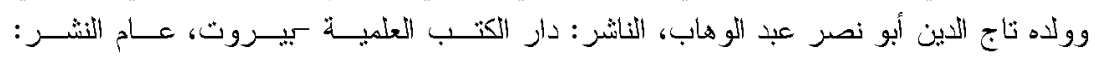

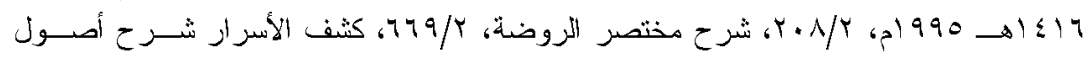
البزدوي 
مجلة كلية الدراسات الإسلامية والعربية للبنات بدمنهور العدد الخامس الجزء التاسع •r+rم

المبحث الثالث: أسباب الخطأ في الفتوى

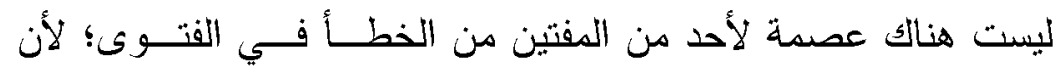

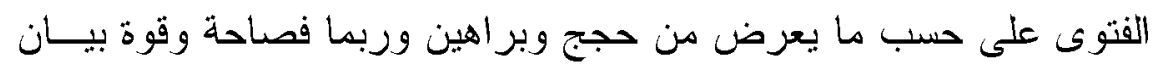

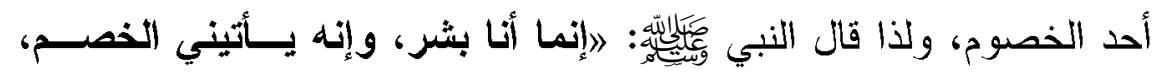
فلعل بعضكم ألحن بحجته من بعض، فأحسب أنه صادق، فأقضي له بذلك،

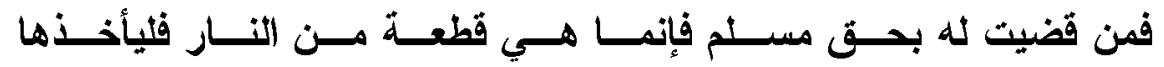

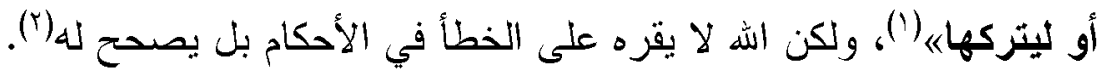

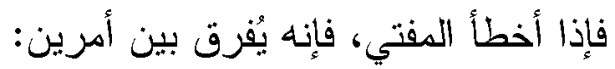

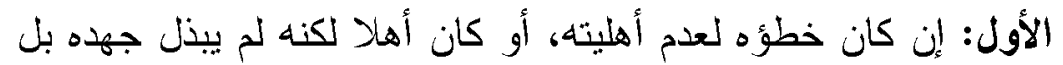

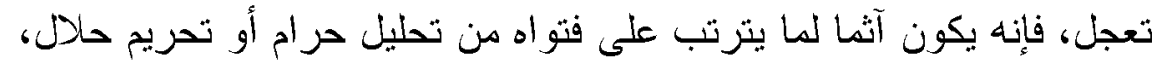
وفي الحديث: 》إن الله لا يقبض العلم انتزاعا ينتزعه من صدور العلمــاء،

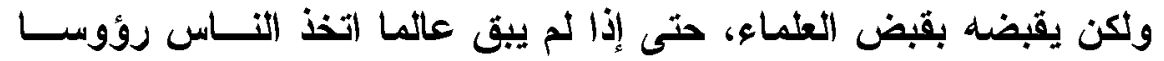

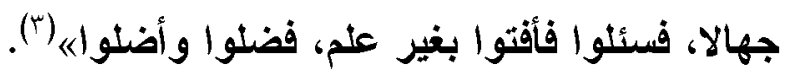

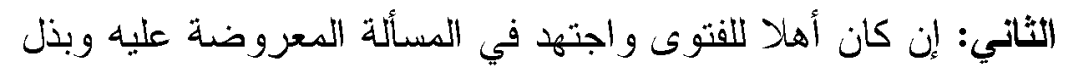
وسعه ولكنه أخطأ الحكم الصحيح فلا إثم عليه، بل له أجر اجتهاده، قياســا

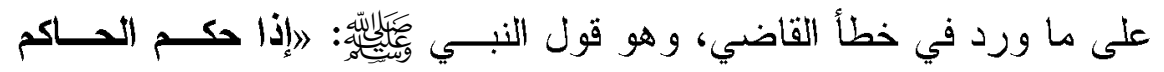

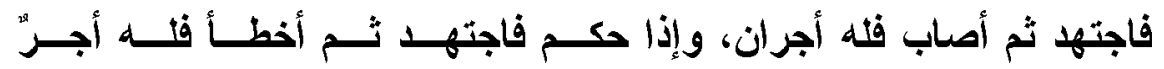

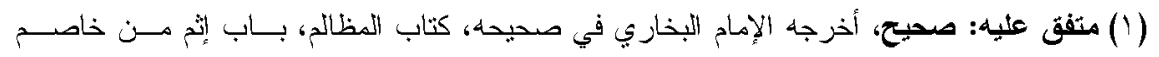

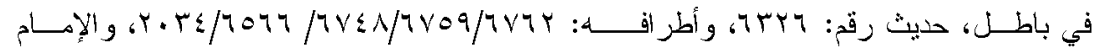

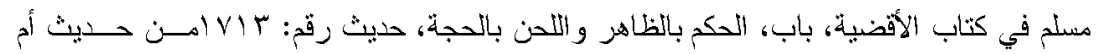
سلمة مرفوعا.

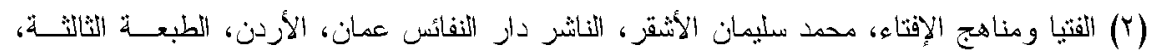

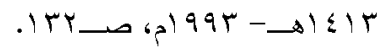

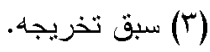




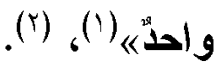

فهذا خبر ورد في أمر الحكم المبني على الاجتهاد فيشمل كل ما يرد

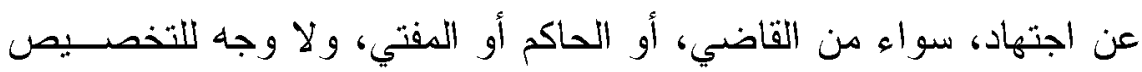

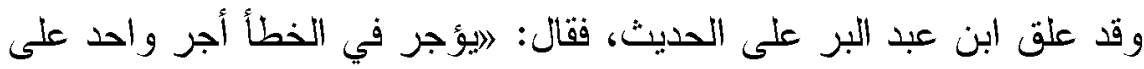

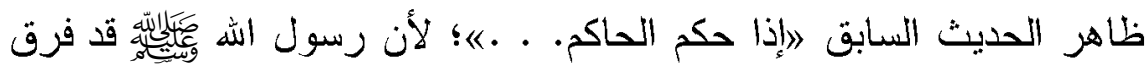

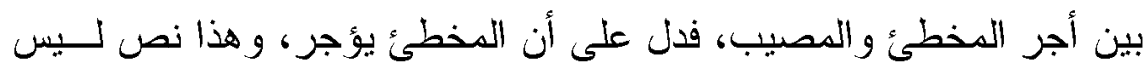

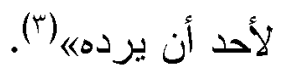

\section{وينقسم الخطأ باعتبار طبيعته إلى قسمين:}

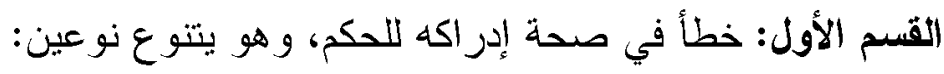

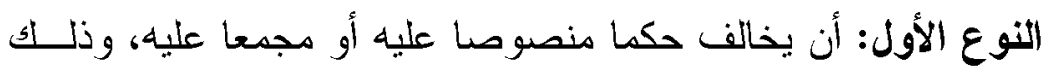
أن يفتي باجتهاده، ثم يتبين له أن هناك نصا صحيحا صريحا أو إجماعـا،

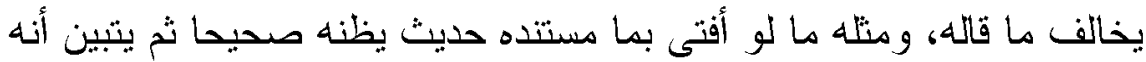
حديث باطل أو ضعيف.

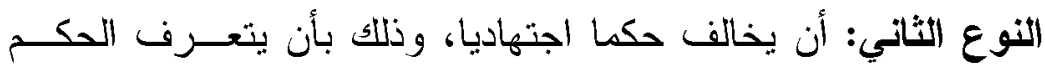

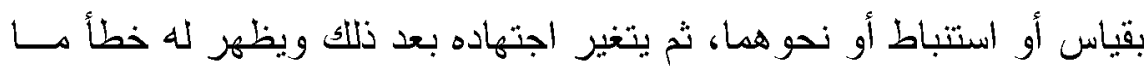

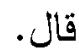

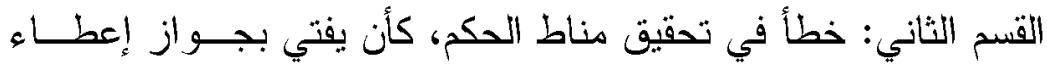

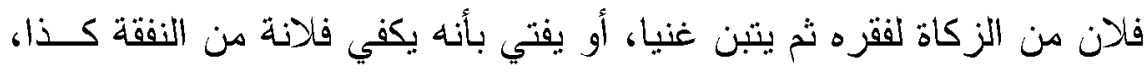

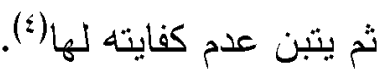

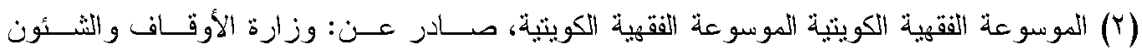

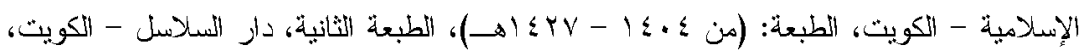

(r) الضو ابط الثرعية للإفتاء عند الأصوليين، الأستاذ الأكتور / عبد الحي عزب، الناثر مكتبة الغــ،

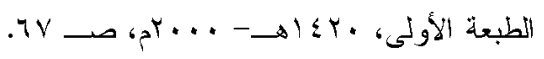

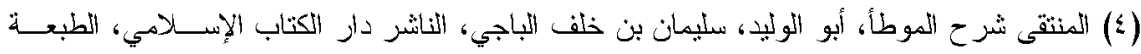

$=$ 
مجلة كلية الدراسات الإسلامية والعربية للبنات بدمنهور العدد الخامس الجزء التاسع •r+rم

وبناء عليه يكون المفتي مأجورا على اجتهاده وإن أخطــأ بالثــروط

التالية:

الأول: أن يكون أهلا للفتيا بأن يستكمل الشروط الو اجبة في المفتي.

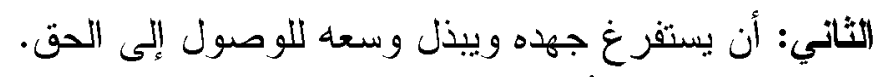

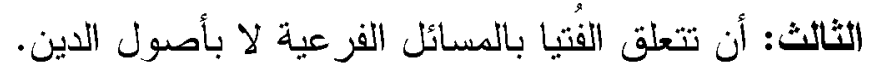

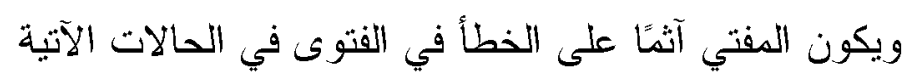

الأول: ألا يكون أهلاً للفتيا.

الثاني: أن يكون قد قصر ولا يكون اهذبذل جهده للوصول إلى الحق

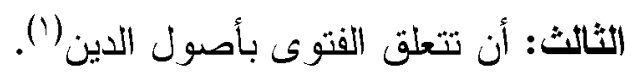

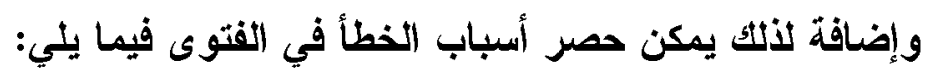

أولا: الفتوى من غير المختصين.

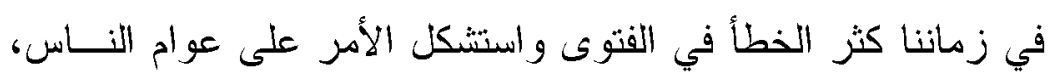

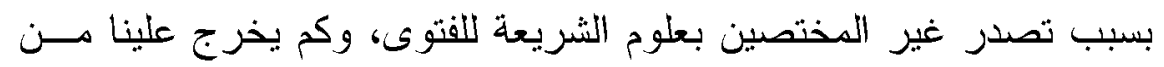

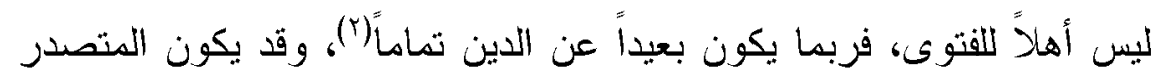

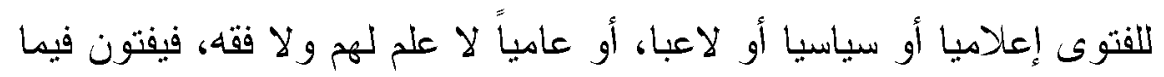
ليس لهم به علم فيضلون ويضلون.

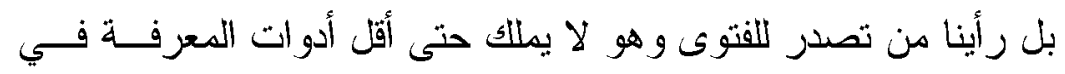

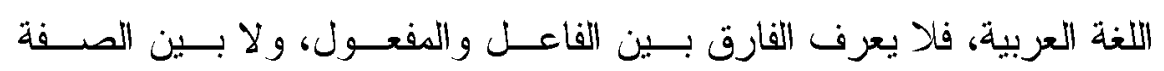

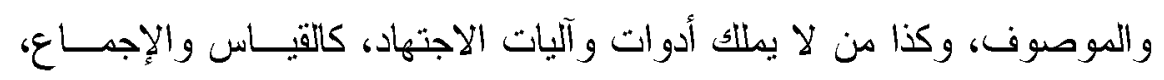

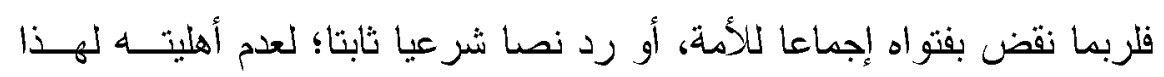

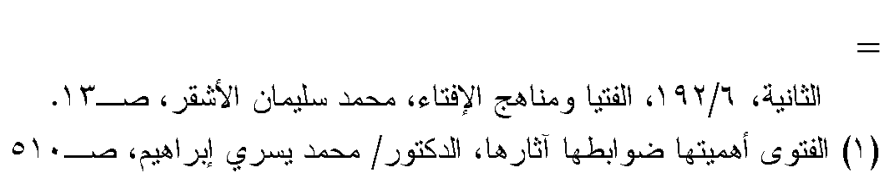

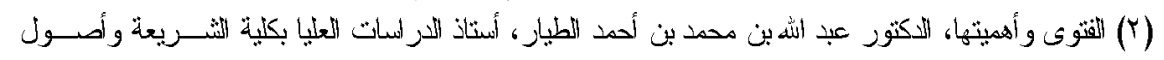

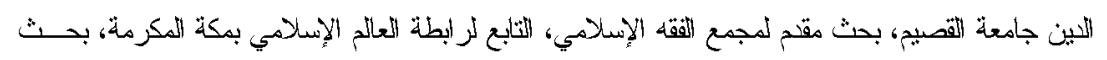

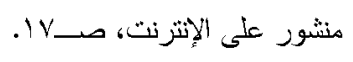


ثنانيا: الجهل بالنصوص أو الغقلة عنها:

و هذا يكثر في نصوص السنة النبوية الثريفة، فقد يكون الثخص على

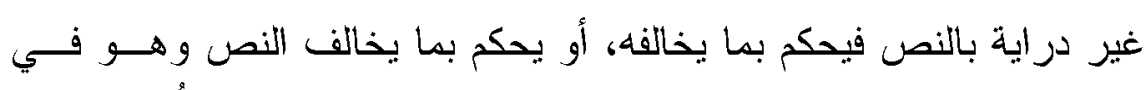

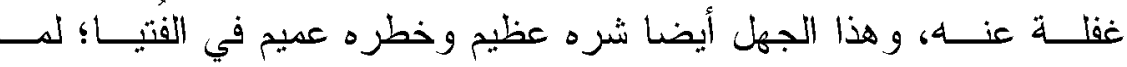

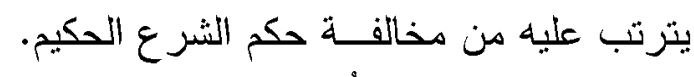

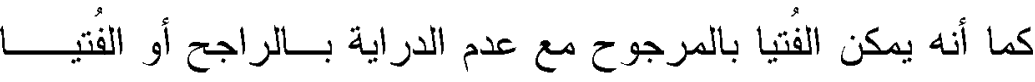

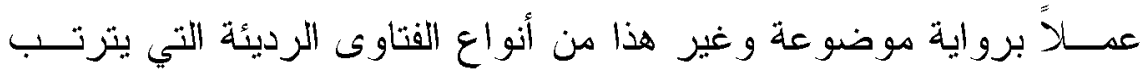

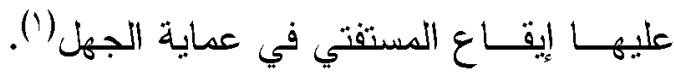
ثالثا: الفهم الخاطئ للنصوص. وذلك يكون بأحد أمرين:

\section{أ- التأويل الخاطئ للنصوص:}

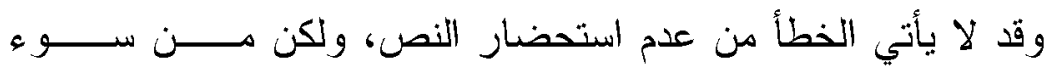

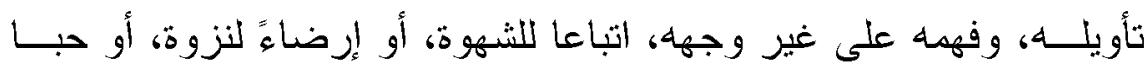

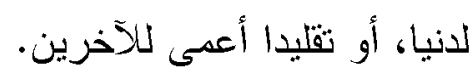

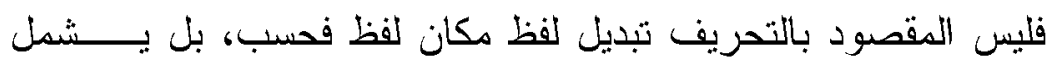

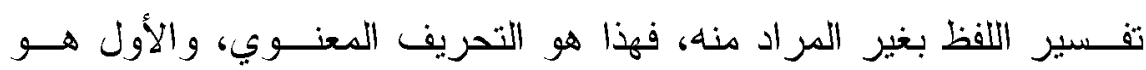
التحريف اللفظي (r).

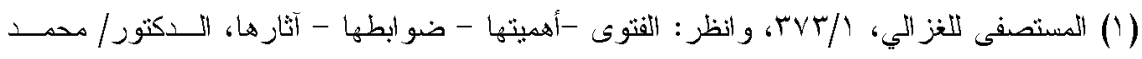

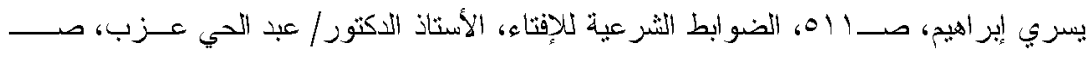


مجلة كلية الدراسات الإسلامية والعربية للبنات بدمنهور العدد الخامس الجزء التاسع •r+rم

\section{ب- الوقوف عن ظواهر النصوص.}

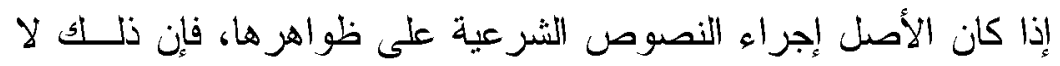

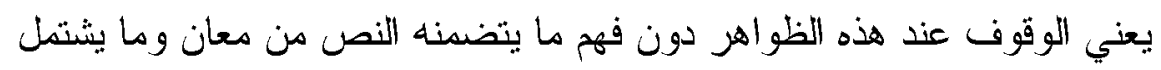

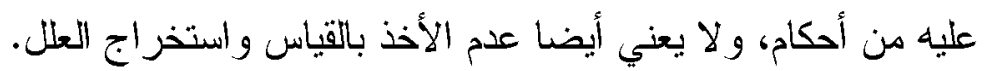
والوقوف عند الجزيئات يؤدي أحيانا إلى التشديد على الناس فئلف في أمور

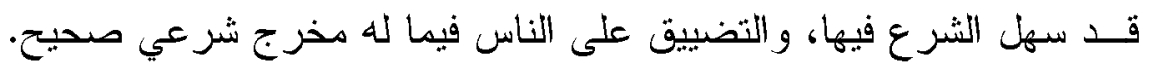

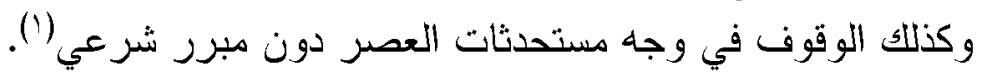

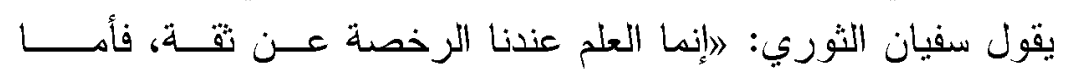

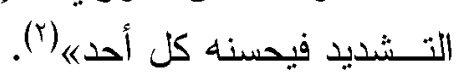

رابعا: تساهل بعض المفتين في إجابة الفتاوى التي ترد علـيهز، دون

النظر إلى من يفتونه (").

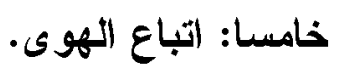

ومن أشد المز الق خطر أعلى المفتي أن يتبع الهوى في فتو اه، ســواء

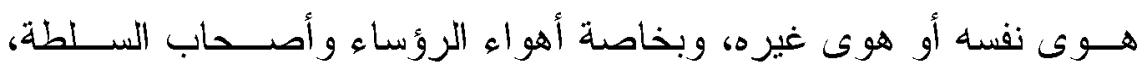

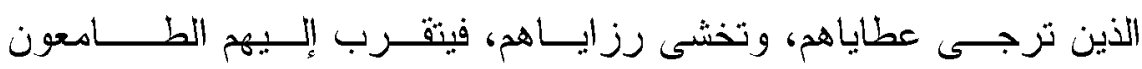

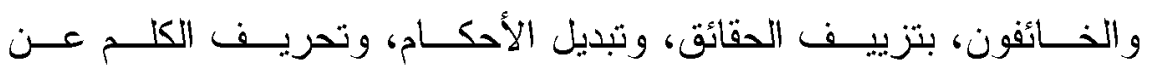

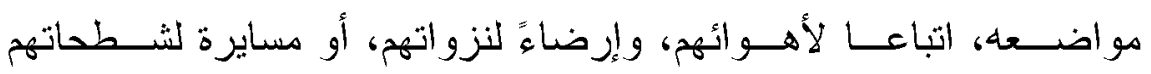
ونطحاتهم.

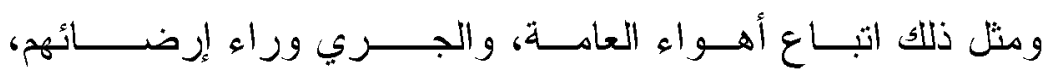

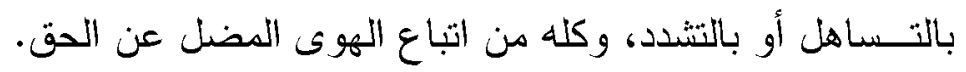

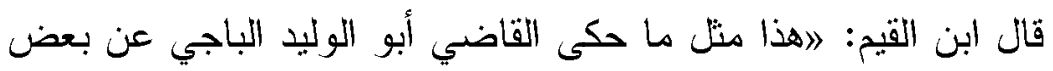

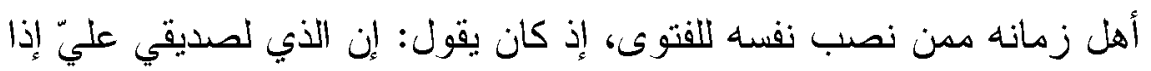

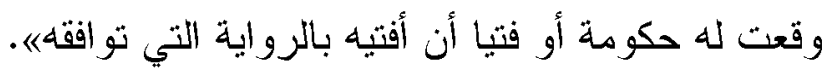

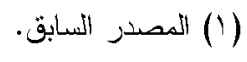

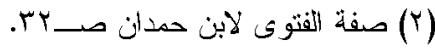

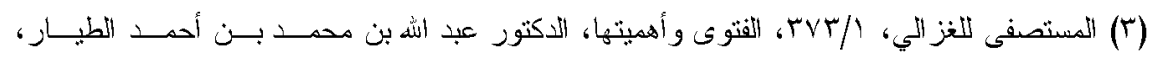


وبالجملة فلا يجوز العمل والإفتاء في ديـن الله ســبحانه بالتشــهي

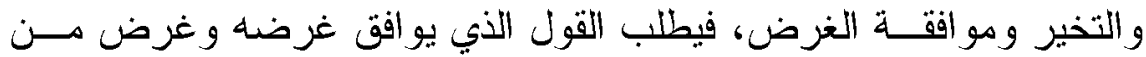

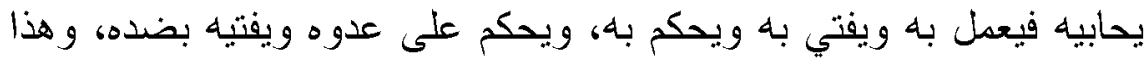

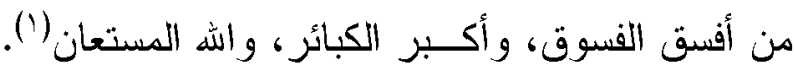
سادسا: الخضوع للواقع المنحرف.

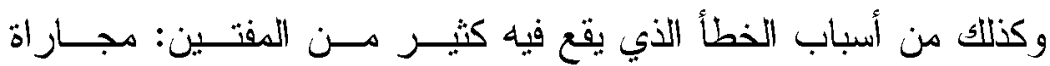

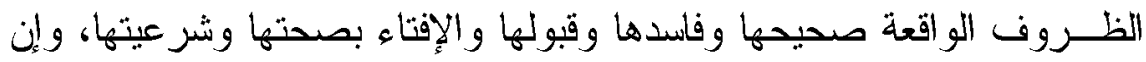

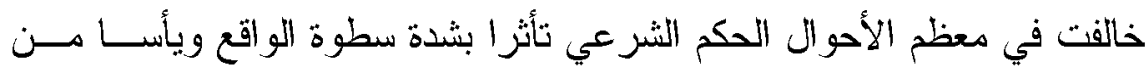

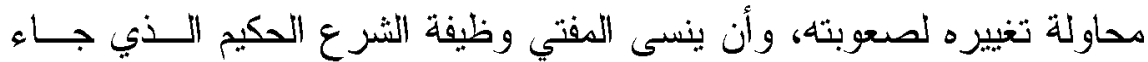

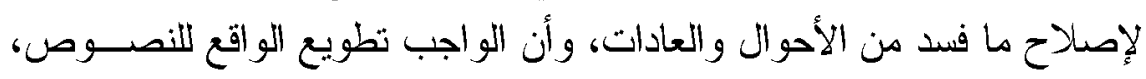

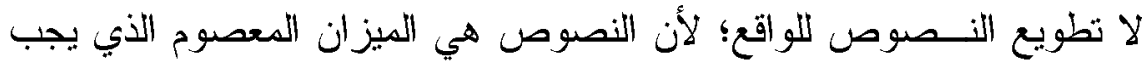

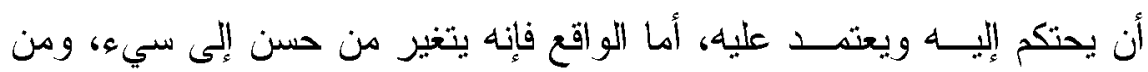

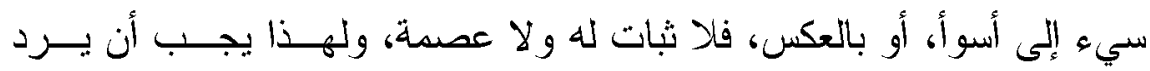

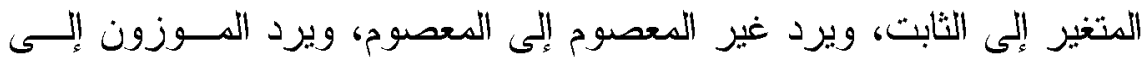
الميز ان (r) (بنغيز سابعا: مراعاة أغراض السائلين وأمزجتهم دون النظر في عواقب الأمسـور

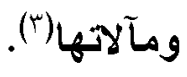

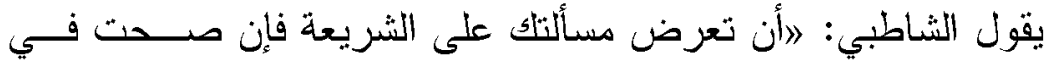

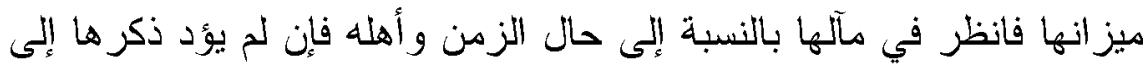

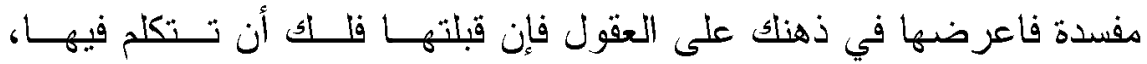

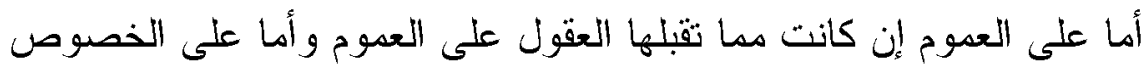

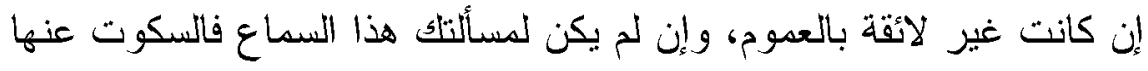

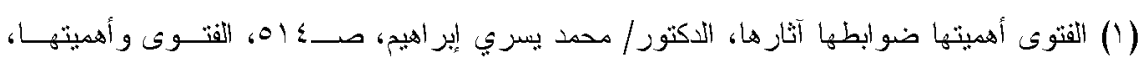

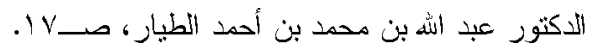

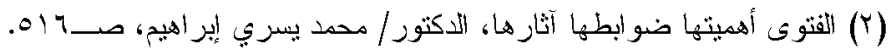

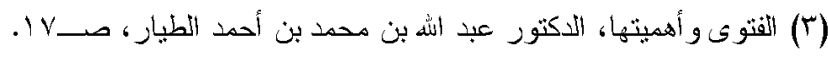


مجلة كلية الدراسات الإسلامية والعربية للبنات بدمنهور العدد الخامس الجزء التاسع •r+rم

هو الجاري على وفق المصلحة الثرعية والعقليةه('). ثامنا: الجمود على القتاوى القديمة دون مراعل القاة الأحوال المتغيرة.

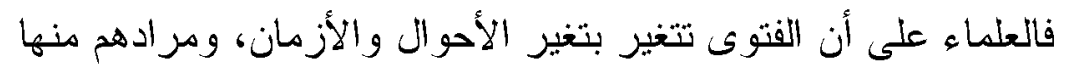

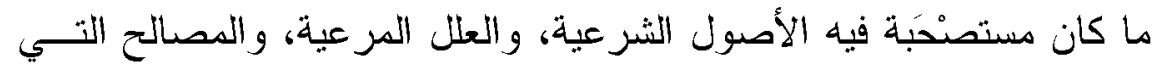

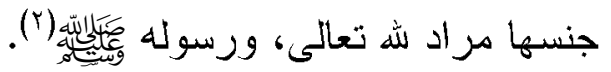
ومن مزالق الفتوى: الجمود على ما سطر في كتب الفقه، أو كتب الفتاوى

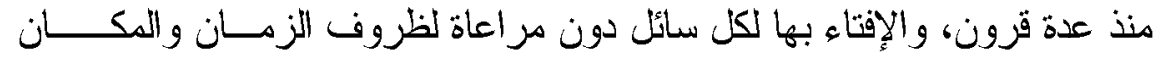

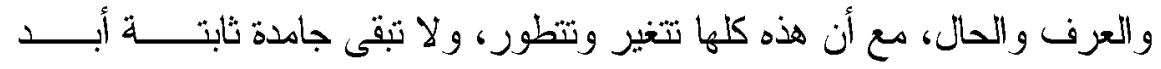
الاهر ("). يقول ابن القيم: 》الثتريعة مبنية على دصالح العباد، هذا فصـلـل عظــيم

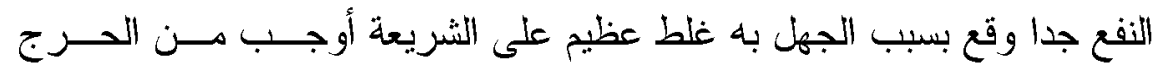

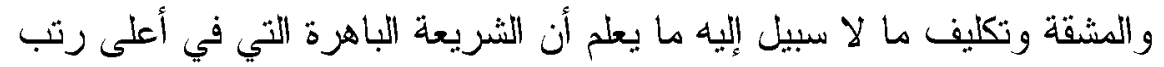

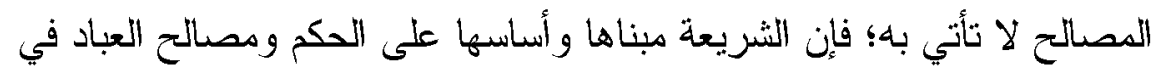

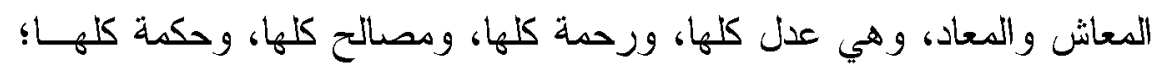

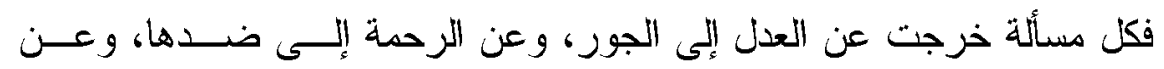

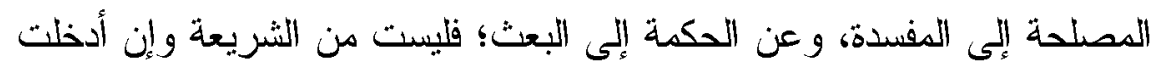

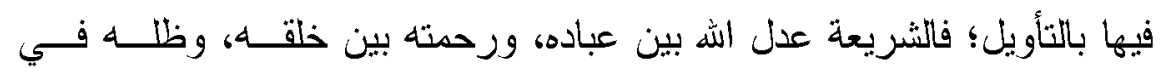

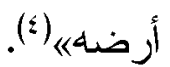

تاسعا: الجهل بمقاصد الثريعة(')

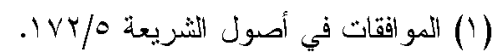

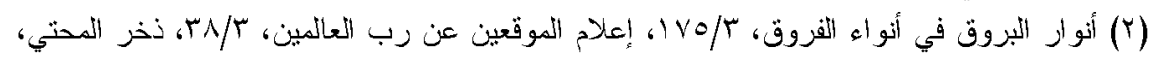

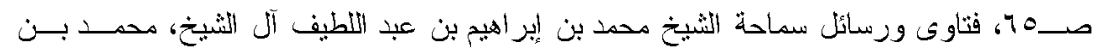

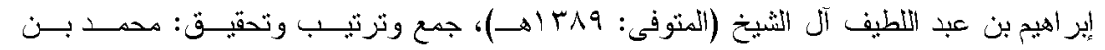

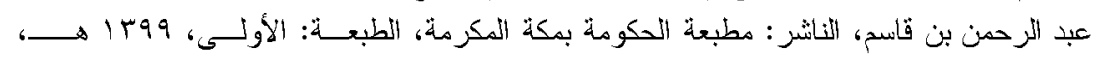

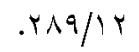

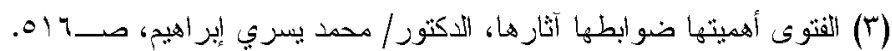

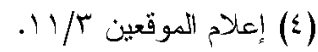

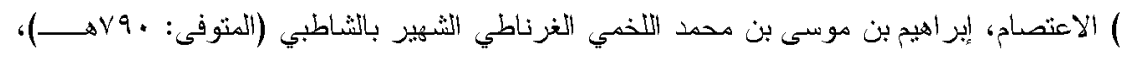


مقاصد الثريعة: هي المعاني الملحوظة في الأحكـــــام الـــــريعة

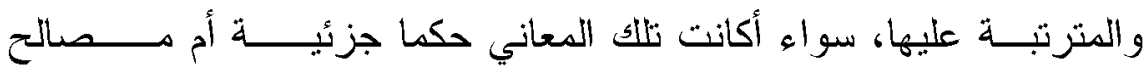

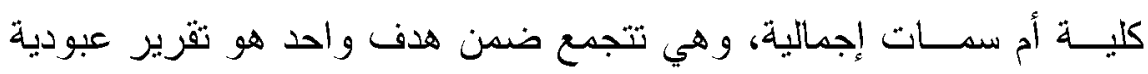
الله تعالى ودصلحة الإنسان (')

و العلم بهذه المقاصد من شروط الاجنهاد، يقول الإمام الثاطبي: 》إنما

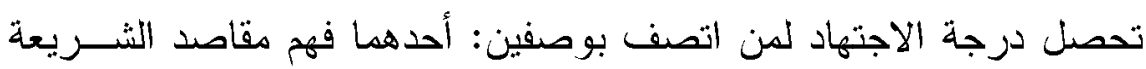

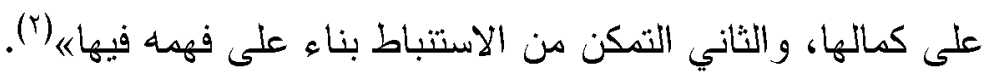

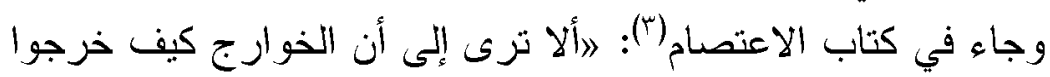

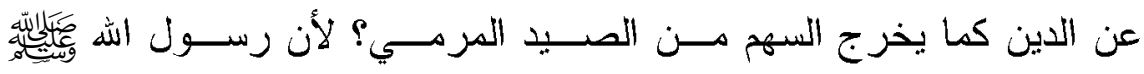

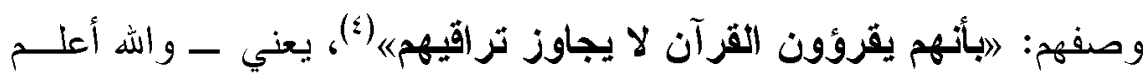

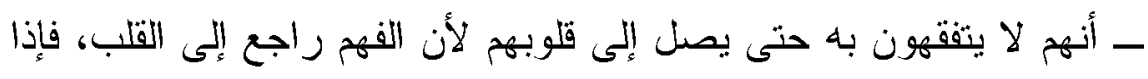

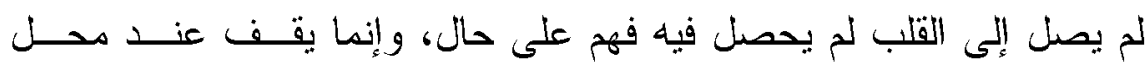
الأصوات و الحروف المسمو عة فقط، وهو الأي يشترك فيه دن يفهر وهــن لا يفهمب.

\section{عاشر ا: التسرع وعدم الاحتراز والحيطة في الفتوى(0).}

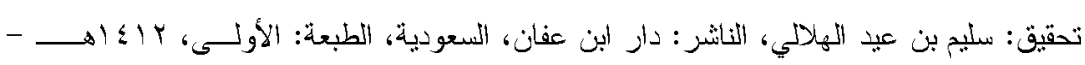

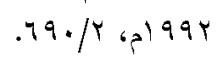

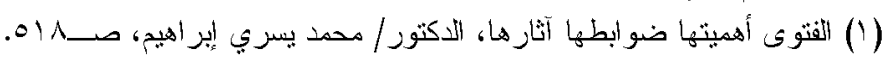

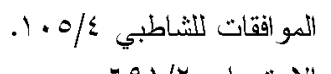

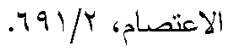

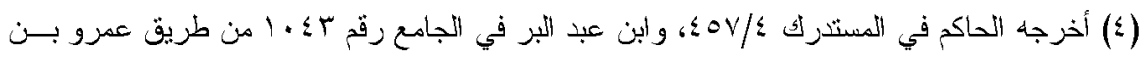

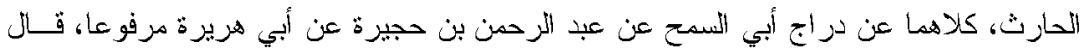

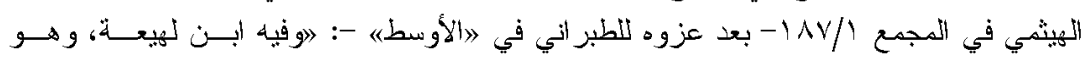

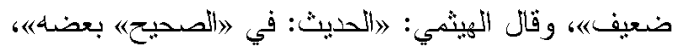

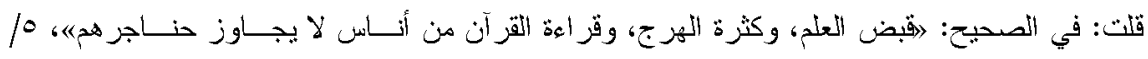

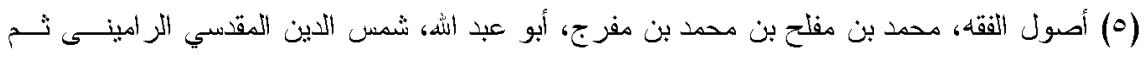

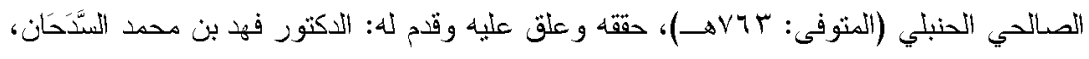

$$
=
$$


مجلة كلية الدراسات الإسلامية والعربية للبنات بدمنهور العدد الخامس الجزء التاسع •r+rم

ومن أهم أسباب الخطأ في الفتوى، التسرع وترك الاحتياط والتثبت.

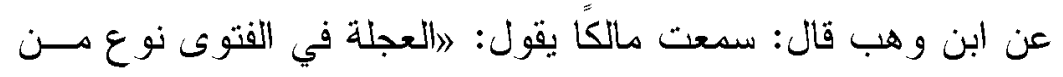

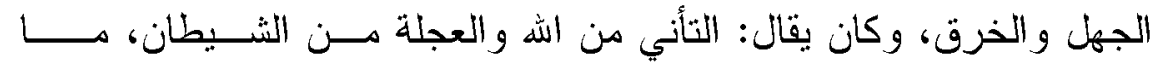

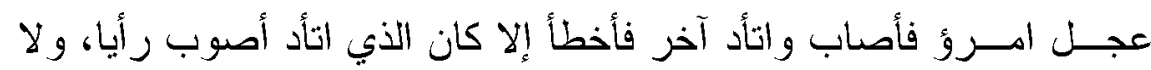

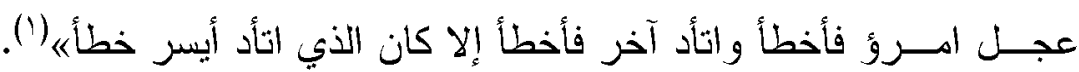

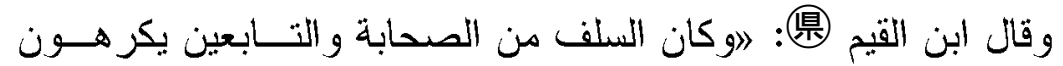

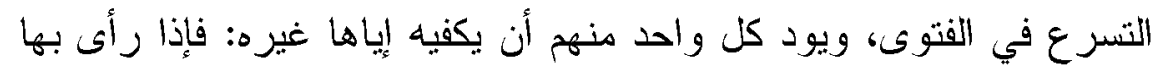

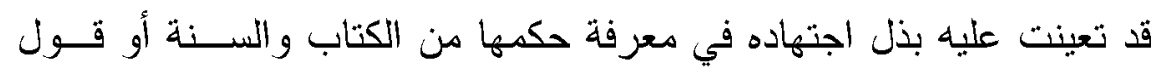

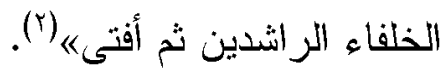

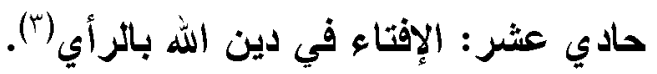

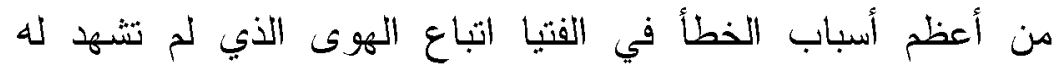

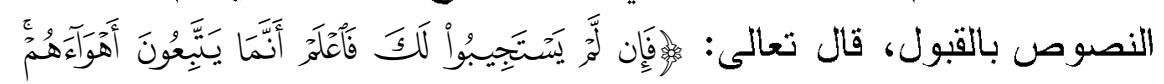

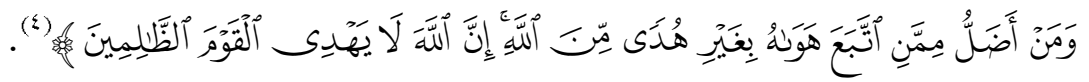

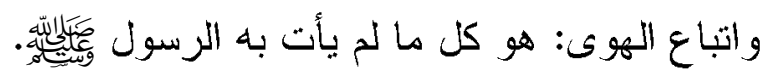

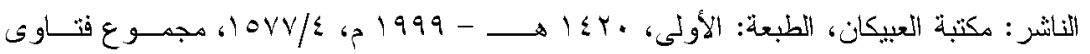

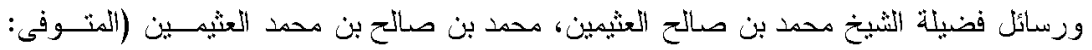

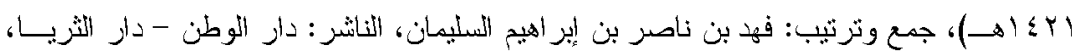
. $1 \mathrm{~V} / Y Y$

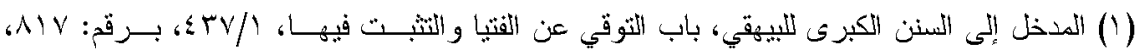

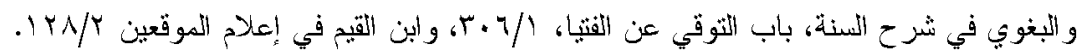
.rV/ إعلام الكوقعين

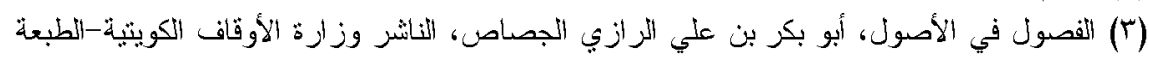

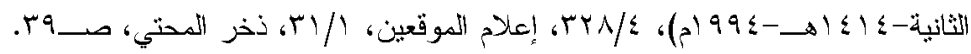
(ع) سورة القصص آية رقم: .0. 


\section{المبحث الرابع: ما يترتب على الخطأ في الفتوى}

أحكام الثريعة من التحريم والتحليل و الإيجاب و النهي مردها إلى الله

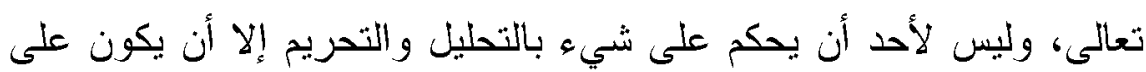

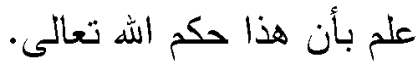

و إذا تبين للفنتي أنه أخطأ في الفتيا وجب عليه الرجوع عن الخطأ إذا

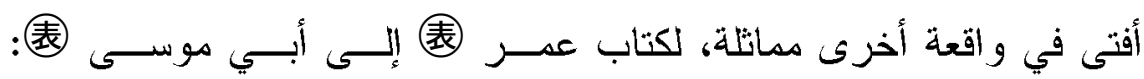

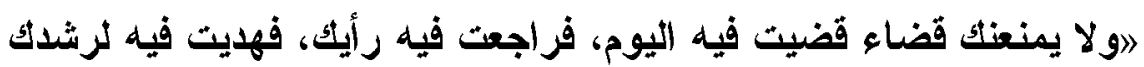

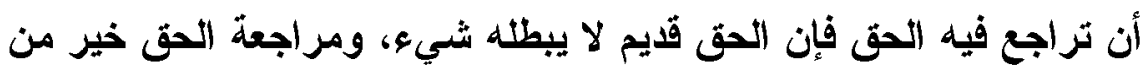

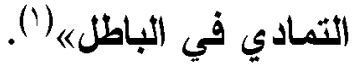

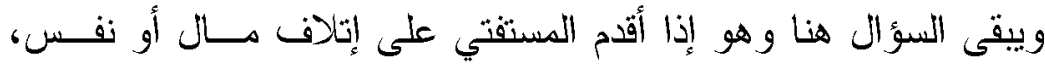

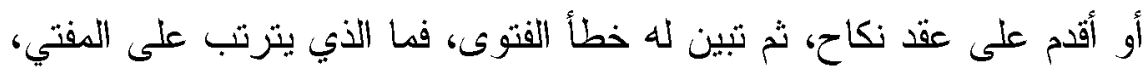

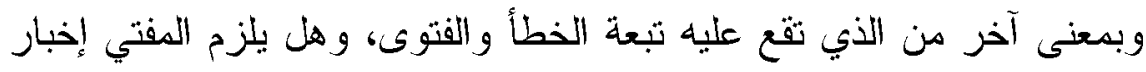

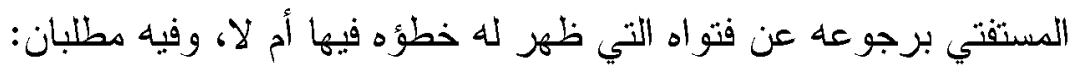
المطلب الأول: هل يلزم المفتي إعلام من استفتاه بخطئه في الفتوى.

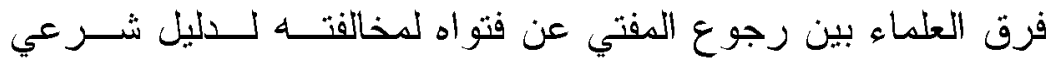

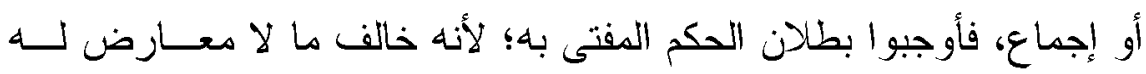

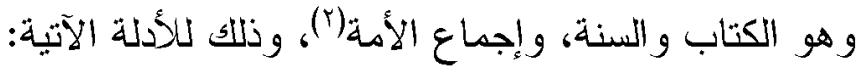

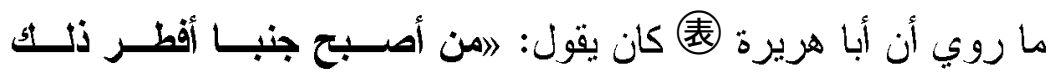

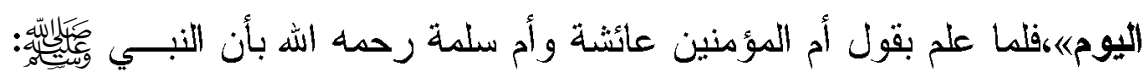

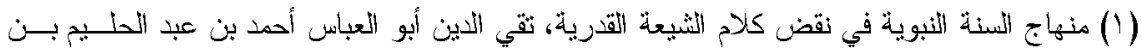

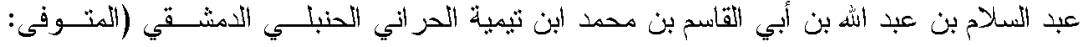

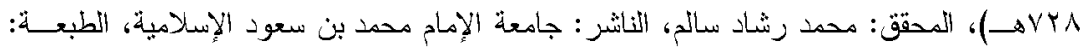

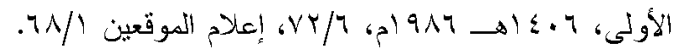

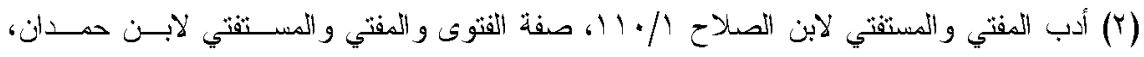

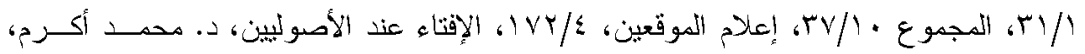


مجلة كلية الدراسات الإسلامية والعربية للبنات بدمنهور العدد الخامس الجزء التاسع •r+rم

》إن كان ليصبح جنبا من جماع غير احتلام ثم يصوم ذلك اليوم)|(") رجع عن

فتو

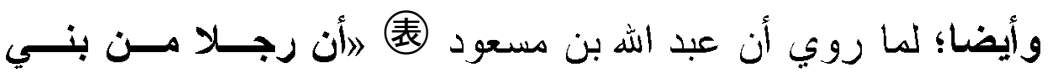

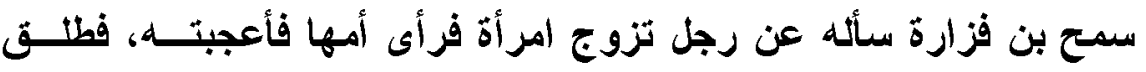

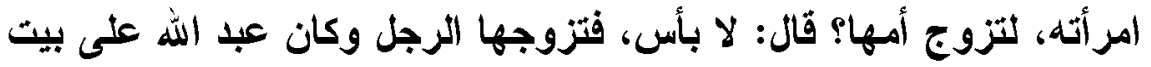

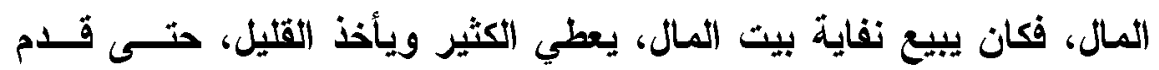

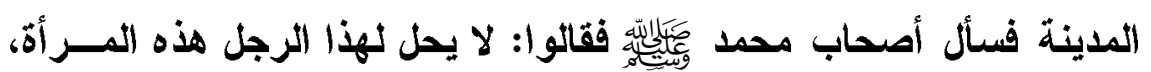

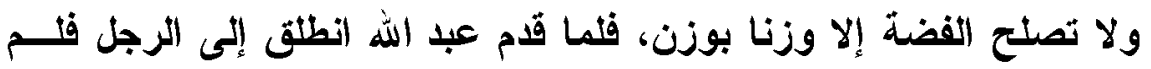

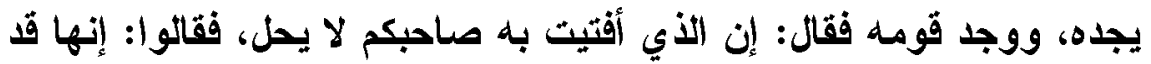

نثرت له بطنها، قال: وإن كان وفرق بينه وبين أهلهي(")

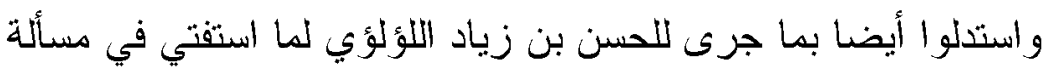

فأخطأ فيها، ولم يعرف الذي أفتاه به، فاستأجر مناديا ينادي أن الحسن بــن فئن

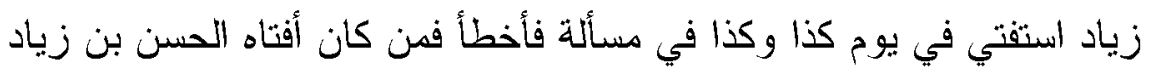

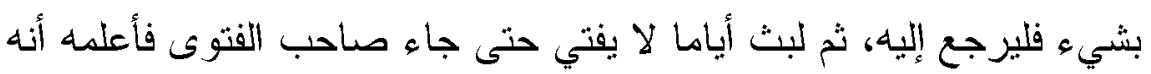

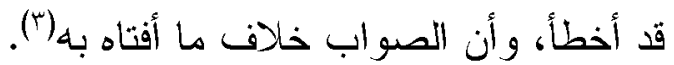

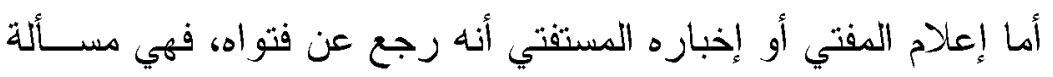

(1) حديث إن كان ليصبح جنبا من غير احتلام، متفق عليه: صحيح، بألفاظ مثقاربة، أخرجه البخـاربي

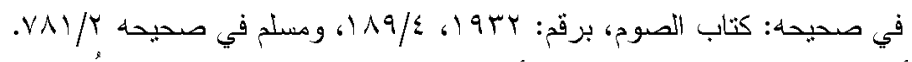

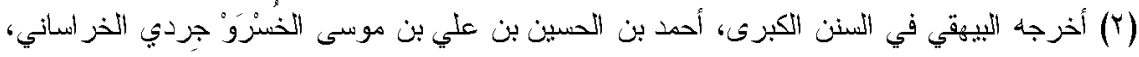

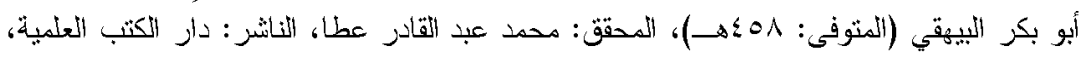

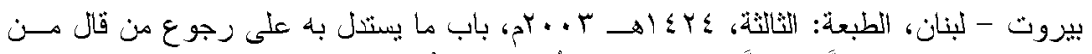

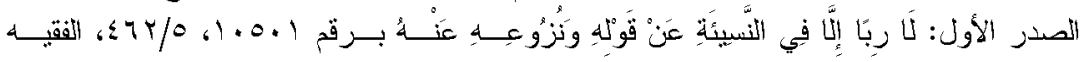

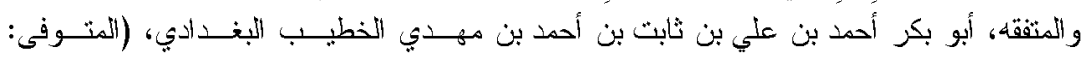

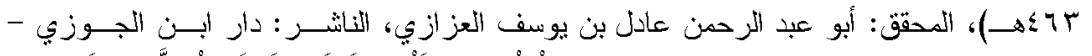

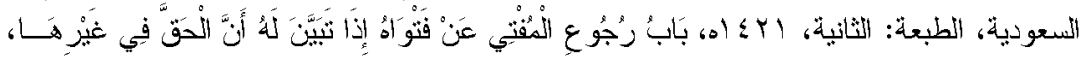

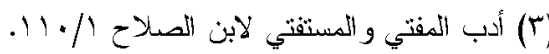


خلافية، اختلف العلماء فيها على أربعة أقوال:

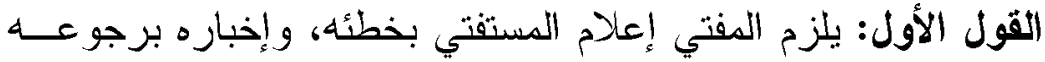

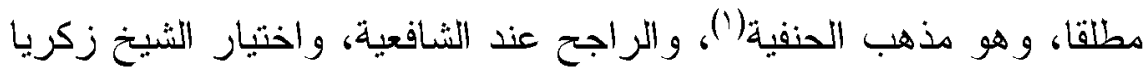

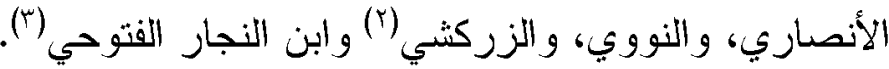

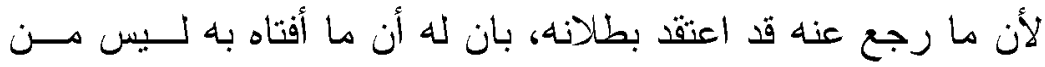

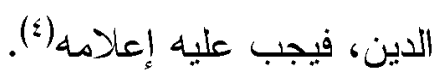

القول الثــاني: دن أفتى بالاجتهاد ثم تغير اجتهاده لم يلزهـــه إعــلام

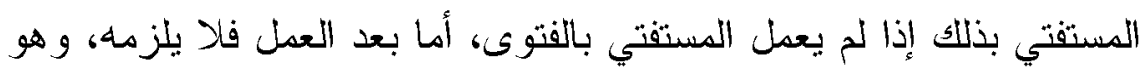

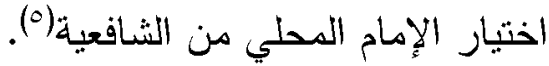

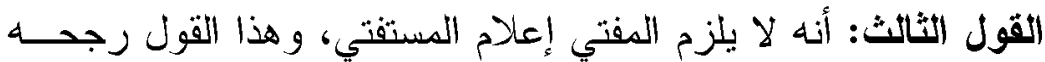

المرداوي وابن مفلح من الحنابلة(").

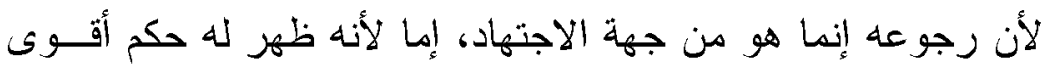

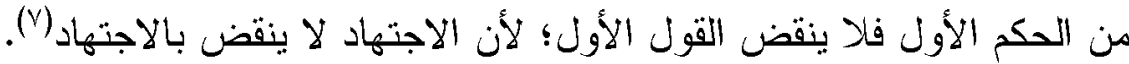

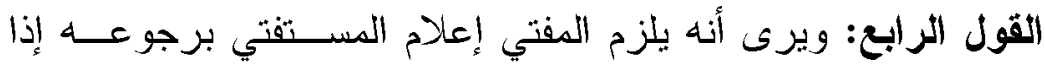

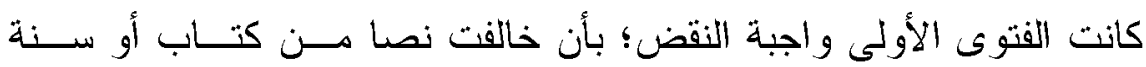

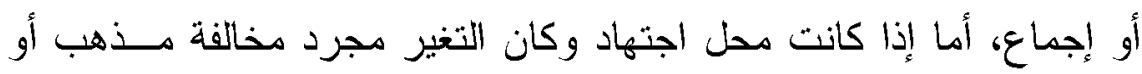

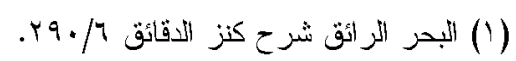

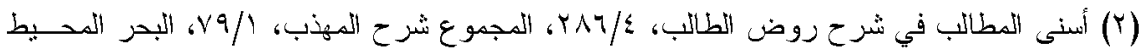

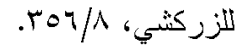

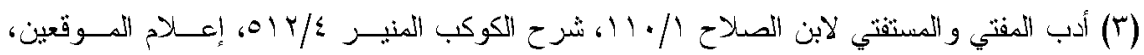

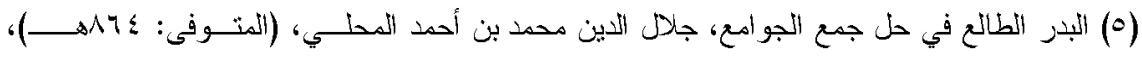

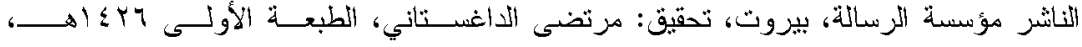


مجلة كلية الدراسات الإسلامية والعربية للبنات بدمنهور العدد الخامس الجزء التاسع •r+rم

قول فلا يلزم المفتي إعلام المستفتي، وهذا القول هو ها ذهب إليه الخطيــب

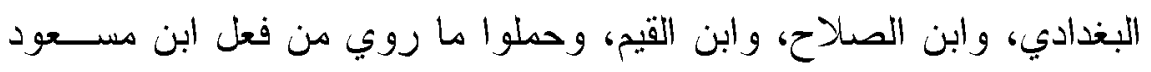
والحسن بن زياد اللؤلؤي على هذا النوع من المسائل (1). المرأي المختار : ون زن

والمختار هو القول الرابع الذي يرى التفصيل بين ها يلــزم الإخبــار

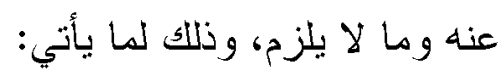
أولا: قوة ما استتد إليه. ثنانيا: جمعه بين الأقو ال السابقة.

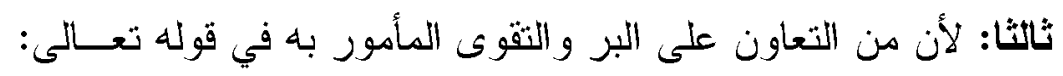

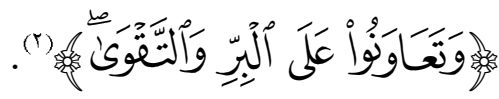

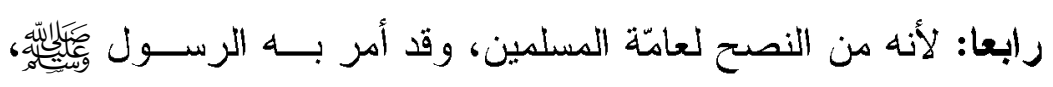

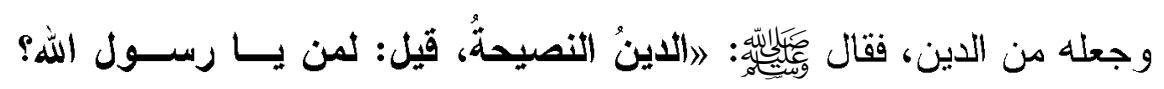

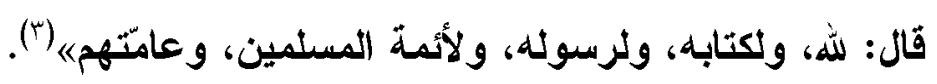

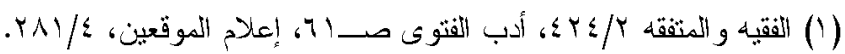

$$
\begin{aligned}
& \text { Y }
\end{aligned}
$$

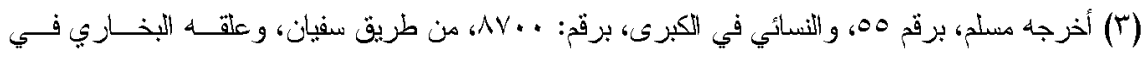

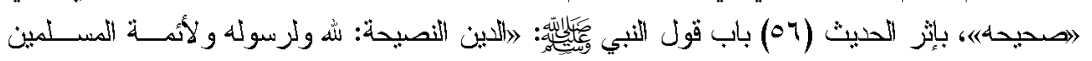

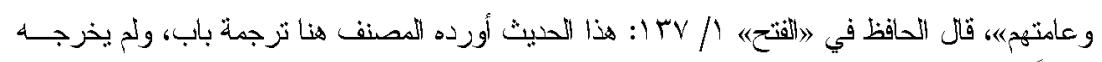

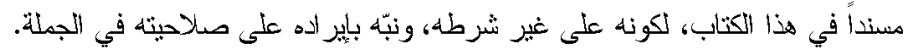

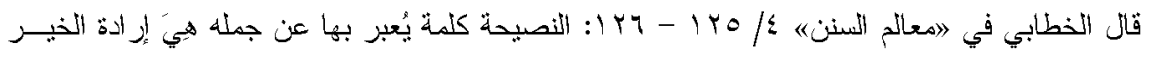

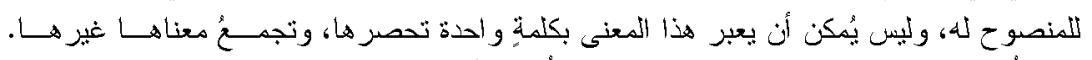

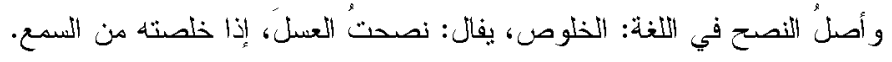


المطلب الثاني: الأثر المترتب على الخطأ في الفتوى.

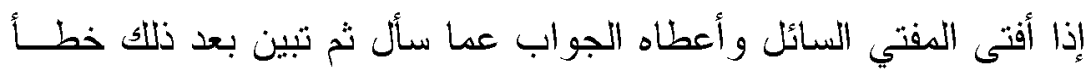

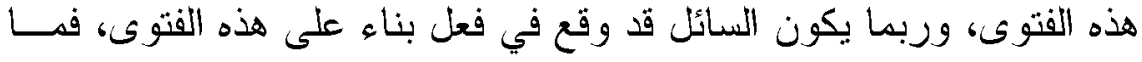
الذي يترتب على هذا الخطأ في حق الدفتي والسائل، وقد انتظم هذا المطلب في دسألنتين على النحو الآتي: المسألة الأولى: آثار الخطأ في الفتوى على الاتئ المفتي.

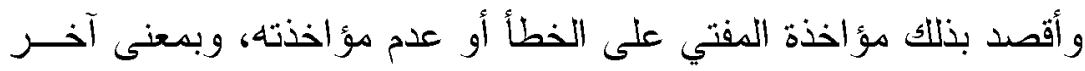

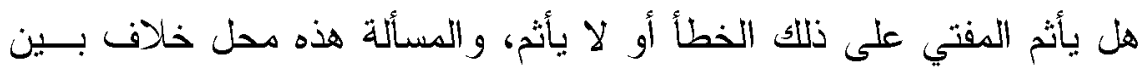
أهل السنة و المعتزلة، وحاصل الخلاف فيها على قولين:

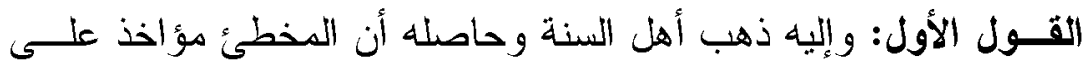

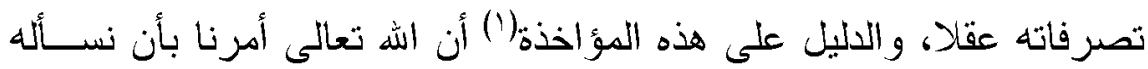

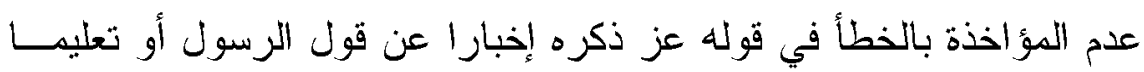

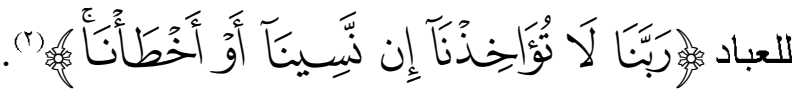

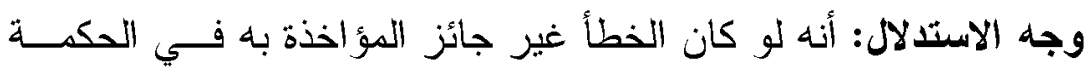

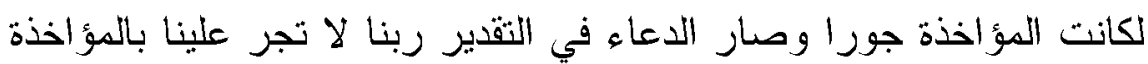

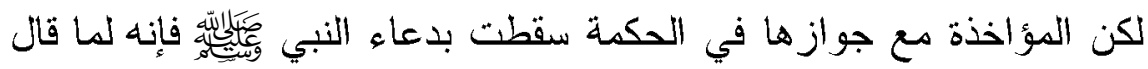
ربنا لا تؤاخذنا إن نسينا أو أخطأنا استجيب له في دعائه(ب).

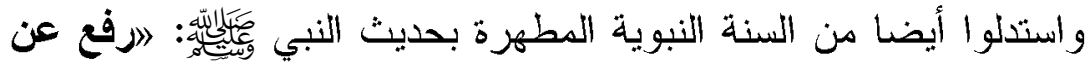

\section{أمتي الخطأ و النسيان وما استكرهوا عليهه(؛).}

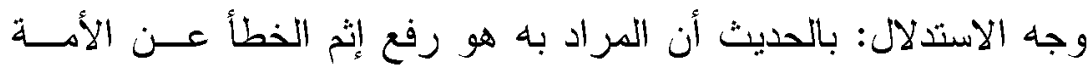

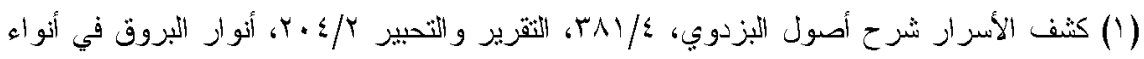

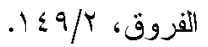

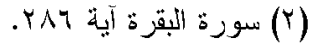
(ז) المصادر السابقة. 
مجلة كلية الدراسات الإسلامية والعربية للبنات بدمنهور العدد الخامس الجزه التاسع •r+rم

و عدم مؤاخذتها عليه

القول الثاني: و إليه ذهب المعتزلة(')، وهو مذهب الثبه الظاهرية(r) وحاصله

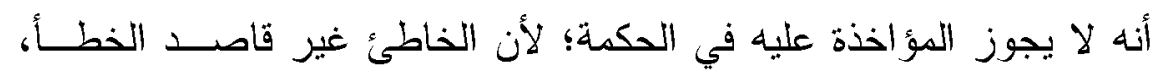
والجناية لا تتحقق بدون القصد.

واستدلو ا على ذلك:

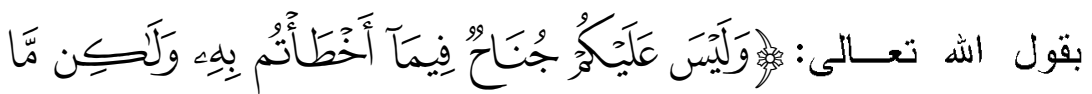

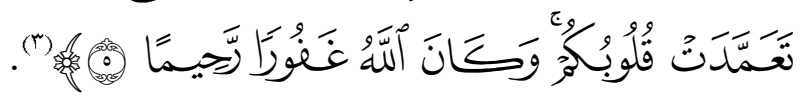

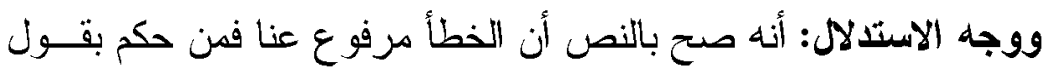

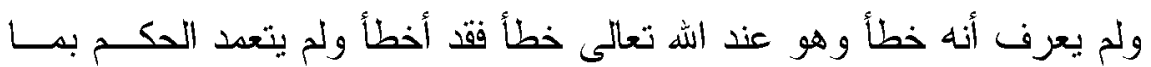

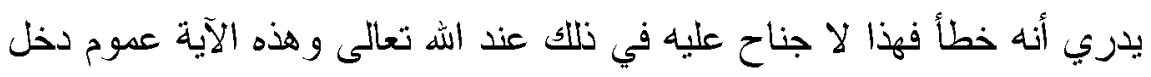

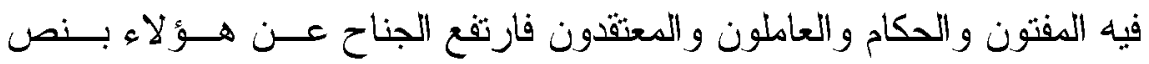

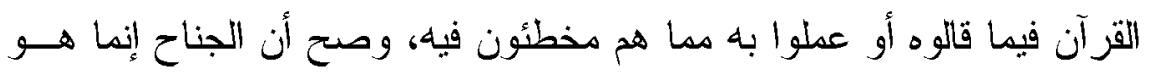

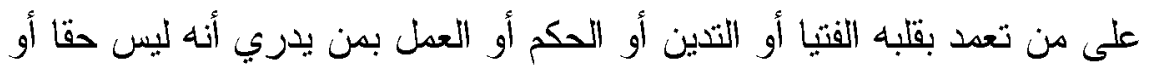

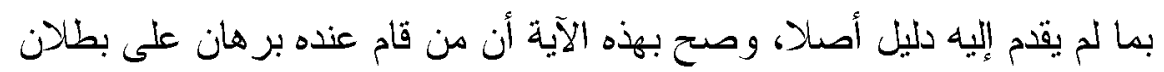
قول فتمادى عليه فهو في جناح؛ لأنه قد تعدد بقلبه ذلك (ء).

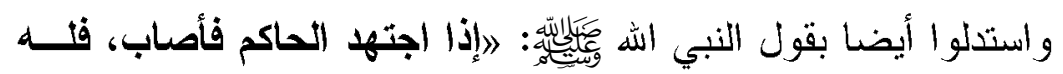

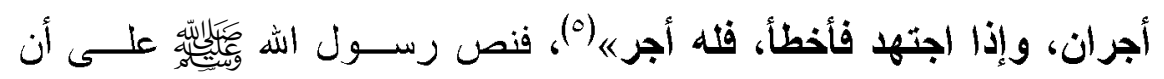

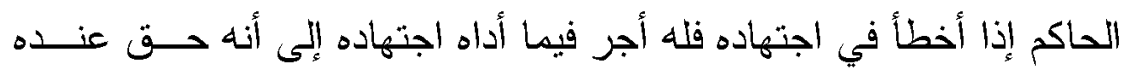

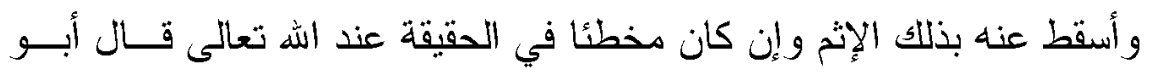

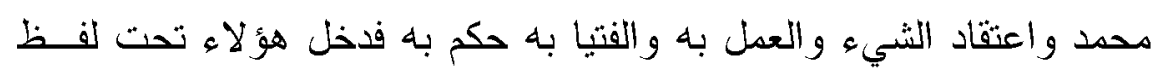

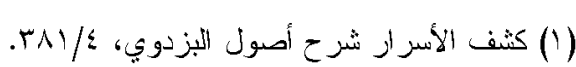

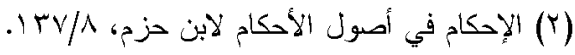

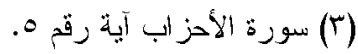

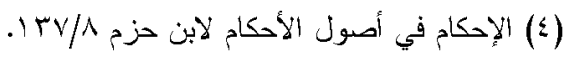

$$
\begin{aligned}
& \text { (0) سبق تخريجه. }
\end{aligned}
$$


الحديث المذكور و عموده فصح ما ذكرناه(").

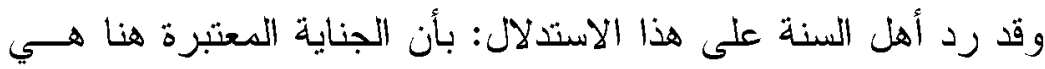

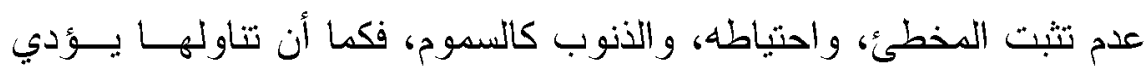

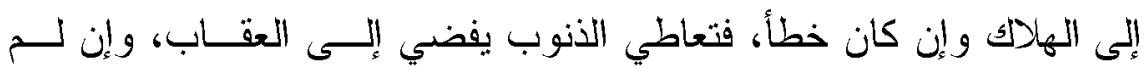

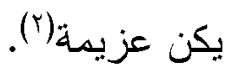
الرأي المختار : - المزي

هو ما ذهب إليه أهل السنة، والمتضمن جواز مؤاخذة الهخطئ عقلا، أمثا،

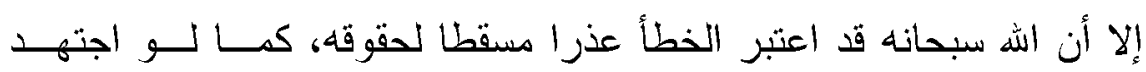
المصلي في تحري القبلة فأخطأ.

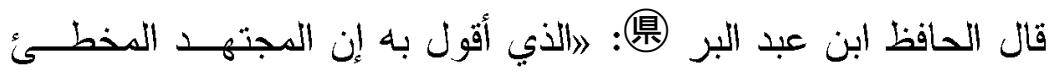

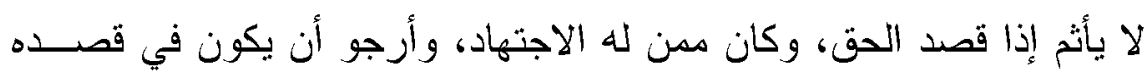

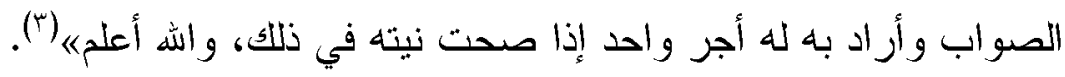
المسألة الثانية: ضمان ما يتلف بناء على الخطأ في الفتوى:

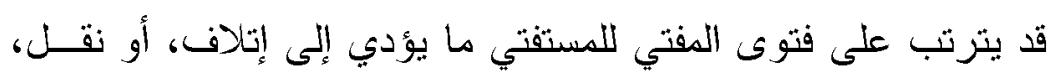

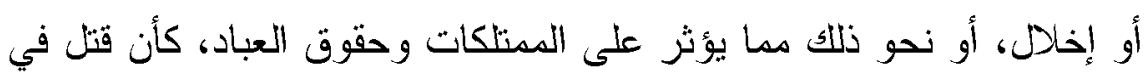

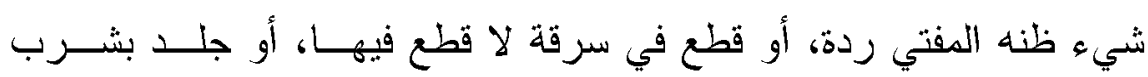

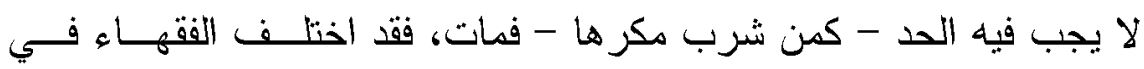

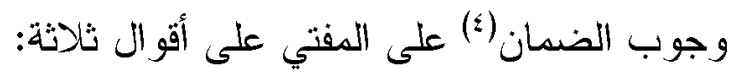

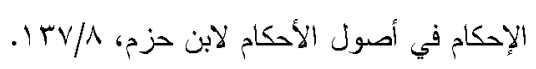

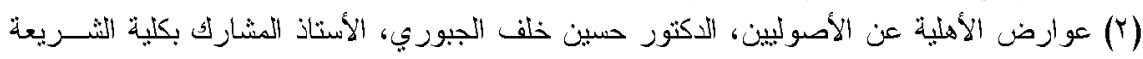

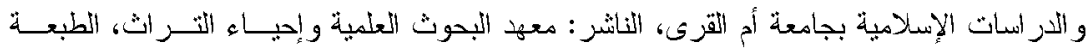

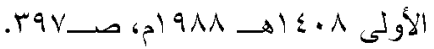

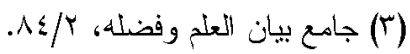

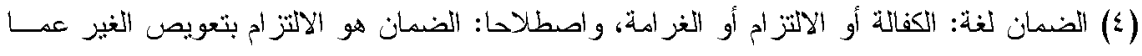

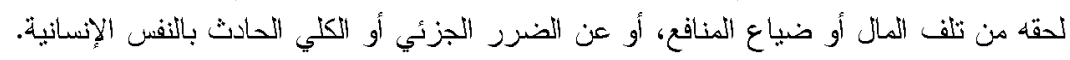

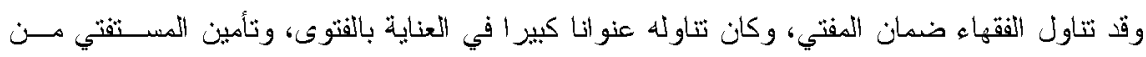

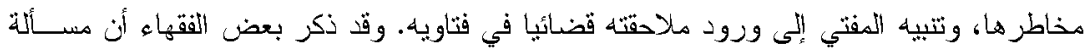
$=$ 
مجلة كلية الدراسات الإسلامية والعربية للبنات بدمنهور العدد الخامس الجزء التاسع •r+rم

القول الأول: وهو المشهور عند الحنفية(') ومذهب المالكية(r)، على ما

نقله الاسوقي عن الحطاب: أن من أتلف بفتو اه شيئا وتبين خطؤه فيها، فـإنان

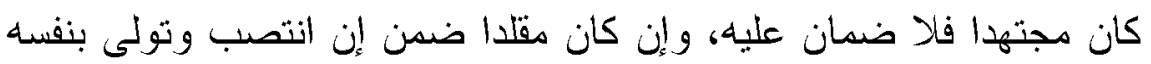

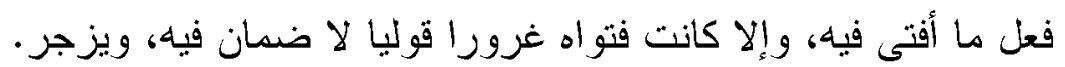

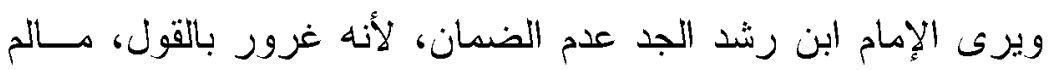

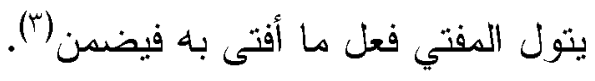

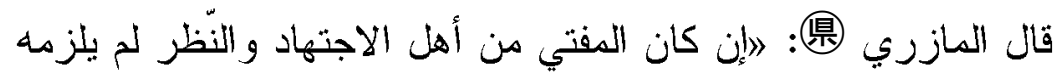

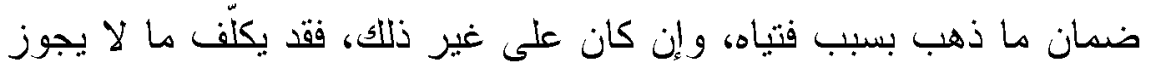

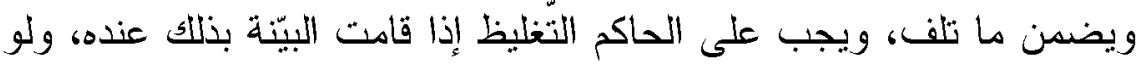
أدّب لكان لذلك أهلا إلّا أن يكون تقدّ له طلب في العلم فيسقط عنــهـ الأدب،

الضمان على الكفتي سواء أكان أهلا للفتوى أو غير أهل لها تشكل عند النظر في مستند القـائلين

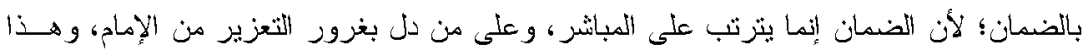

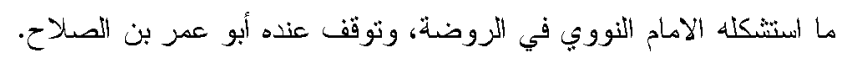

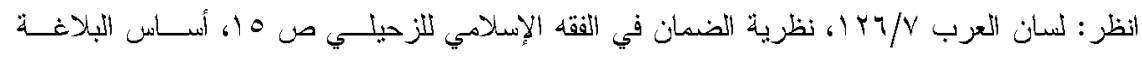

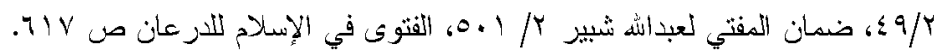

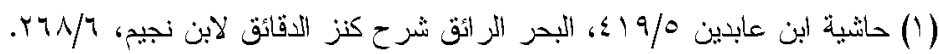

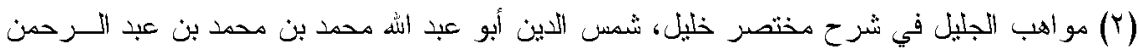

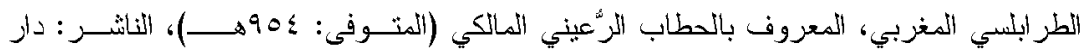

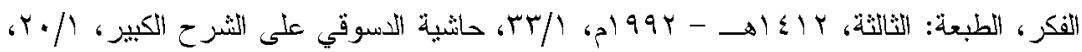

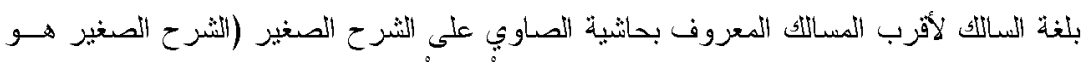

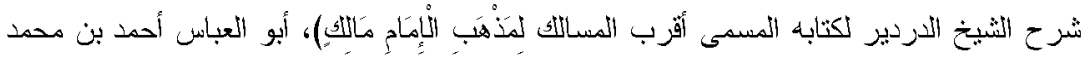

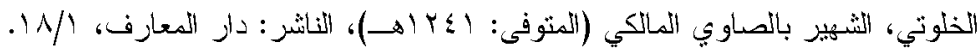

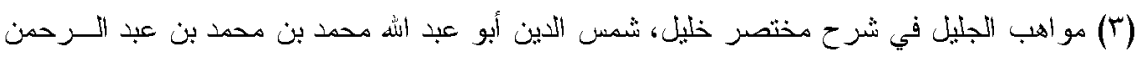

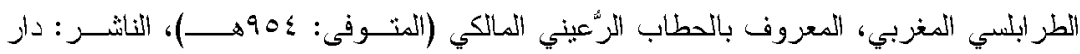

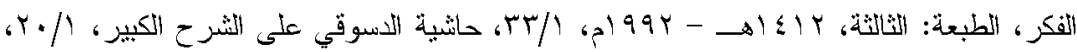

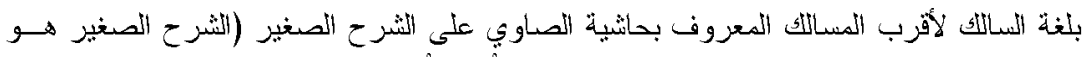

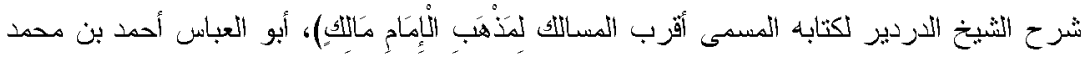

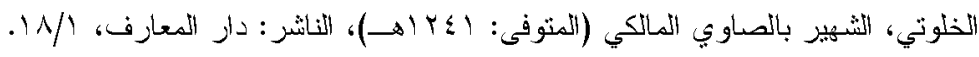


وينهى عن الفتوى إذا لم يكن لذلك أهلاه('). القول الثاني: وهو المشهور عند الثشافعية عكس هذا، ثال النــوبـي:

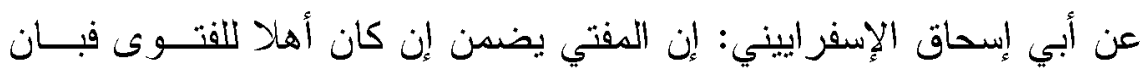

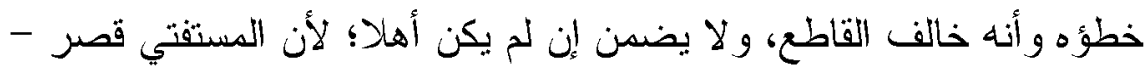

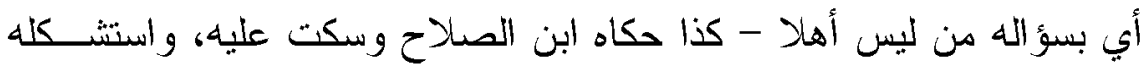

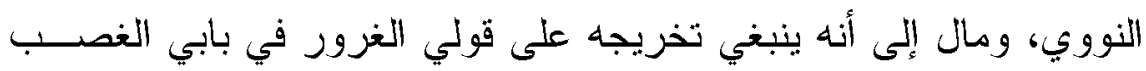

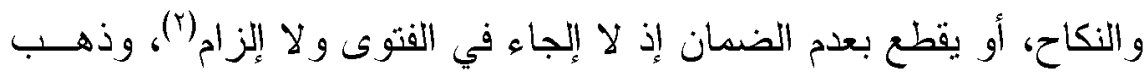

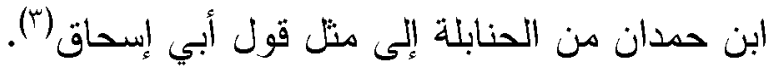

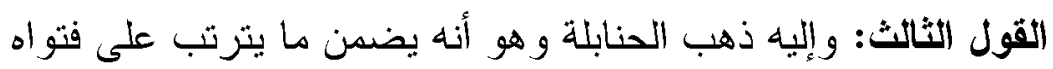

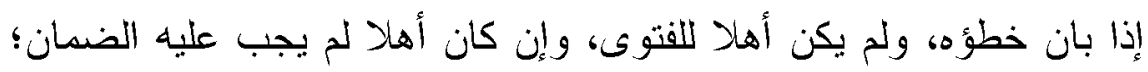

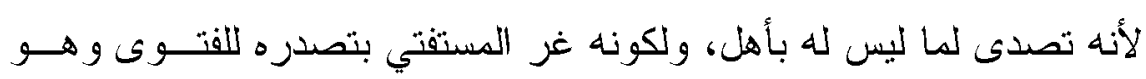

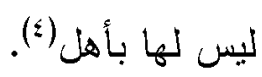

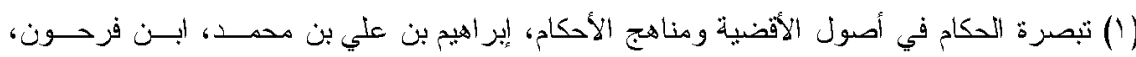

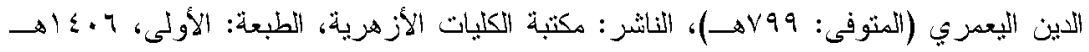

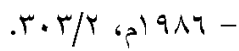

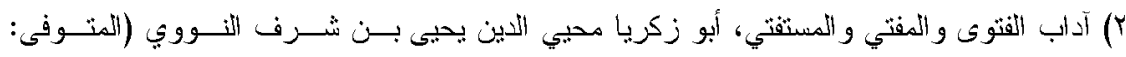

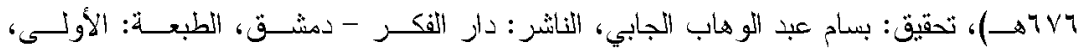

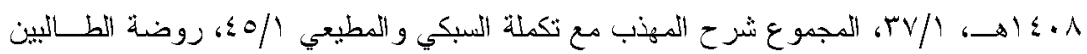

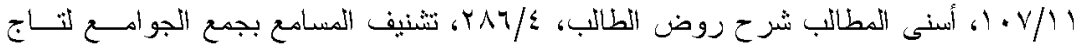

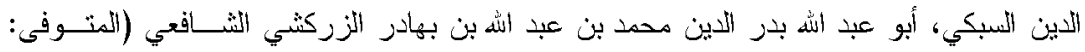

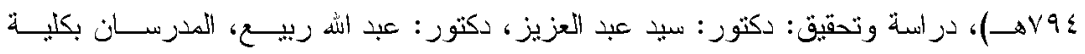

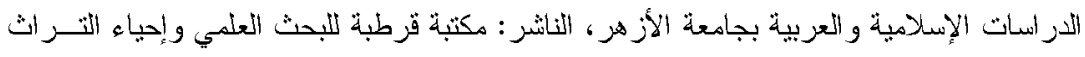

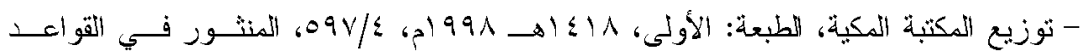

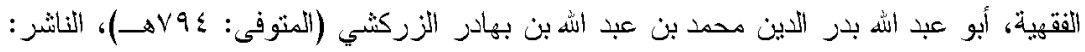

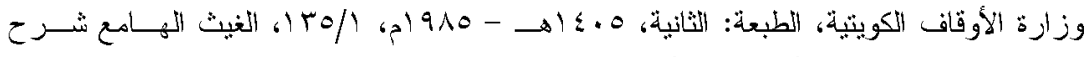

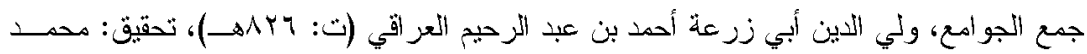

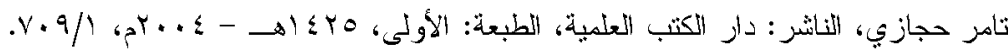

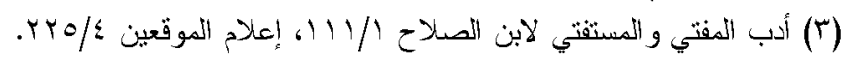

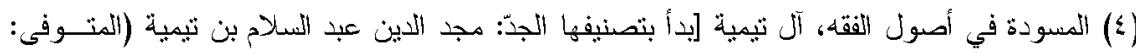

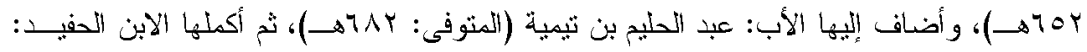

$=$ 
مجلة كلية الدراسات الإسلامية والعربية للبنات بدمنهور العدد الخامس الجزء التاسع •r+rم

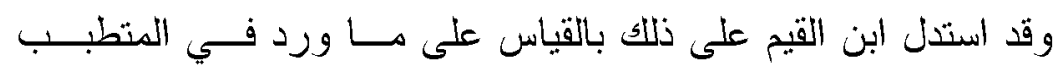

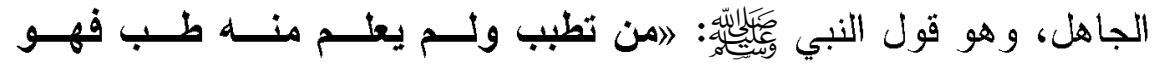

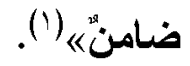

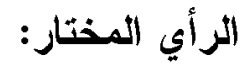

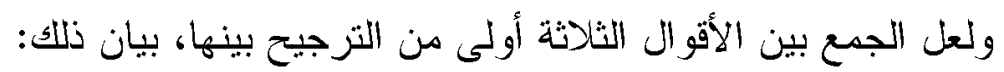

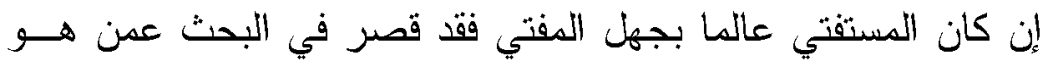

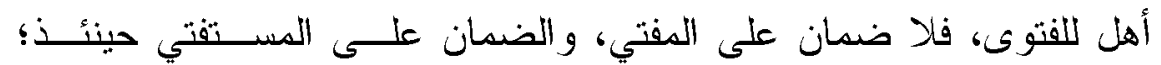

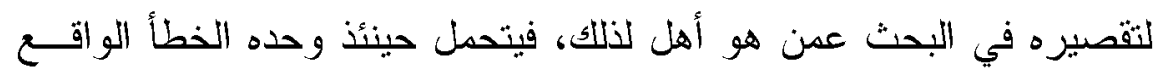
لذلك التقصير . نان.

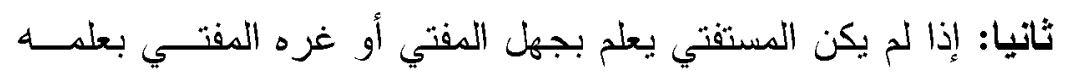

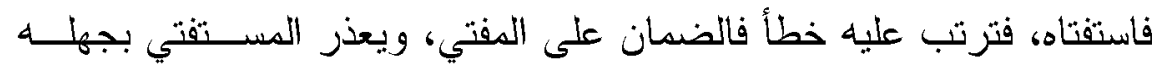

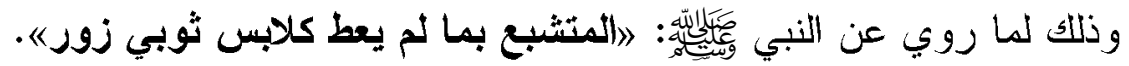

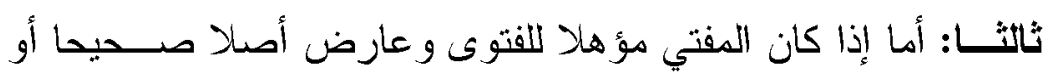

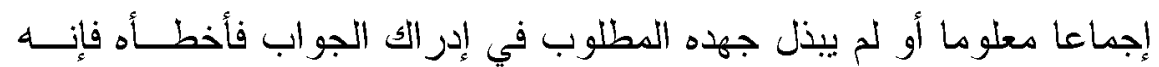

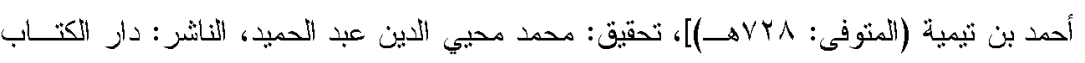

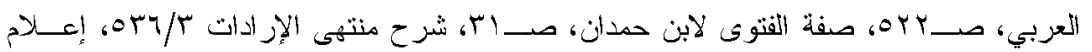

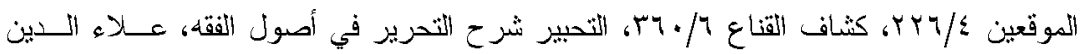

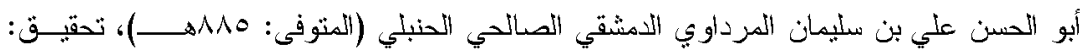

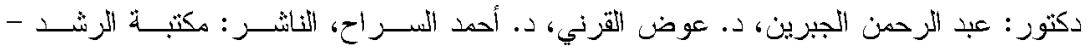

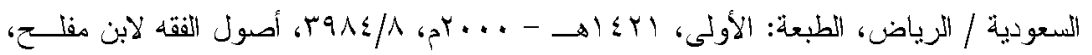

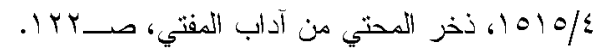

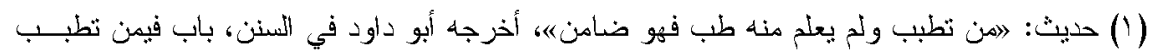

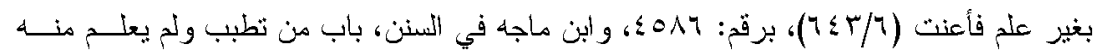

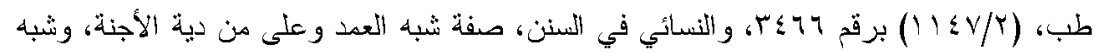

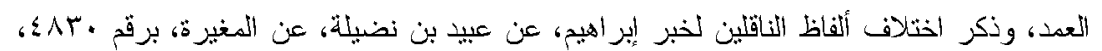

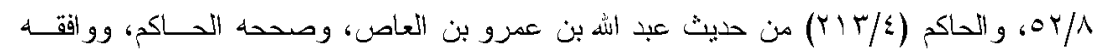
الأهبي. 
يضمن؛ و لا يعذره الثارع، بل يترتب على خطئه إثما؛ لأنه قصر متعدــدا،

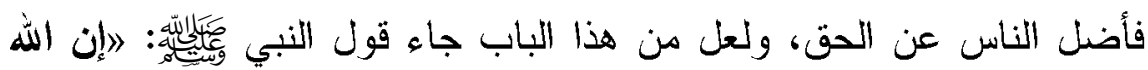

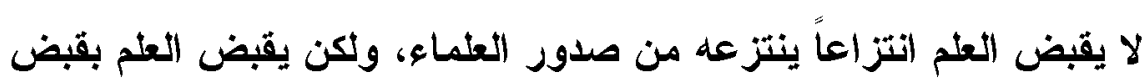

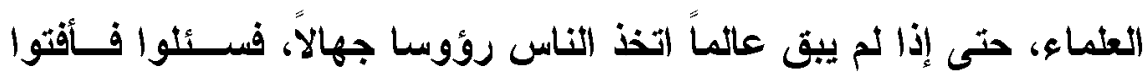
بغير علم فضلوا وأضلواها (1). رابعا: إن كان المفتي مؤهلا للإِفتاء وتو افرت فيه شَــروطه، وبـــل

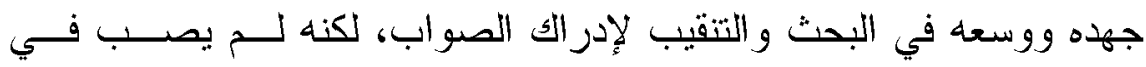

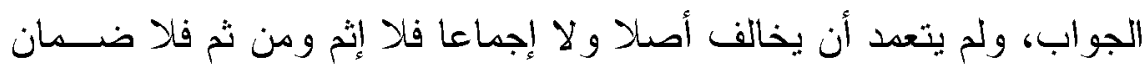
عليه في هذه الحالة؛ لأنه لم يتعد ولم يفرط، و غاية الأمر أنه اجتهد فأخطأ. 
مجلة كلية الدراسات الإسلامية والعربية للبنات بدمنهور العدد الخامس الجزه التاسع •r+rم

\section{الخاتمة}

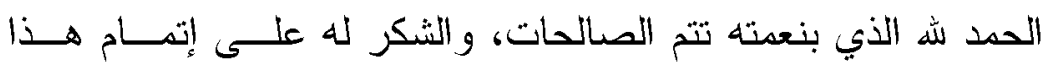
البحث، وقد ظهر لي من خلاده نتائج ألخص أبرزها في في النقاط الآتية:

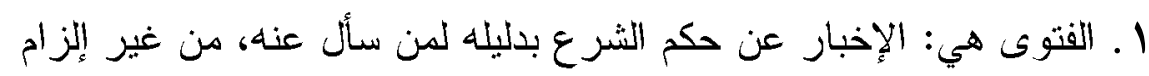

Y. الإفتاء كسؤولية خطيرة وههمة كبيرة، وهنصب عظيم جسيم لهذا عبــر

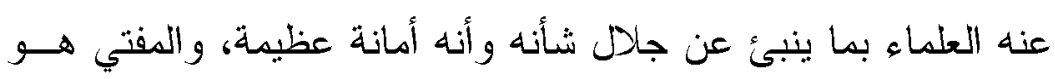

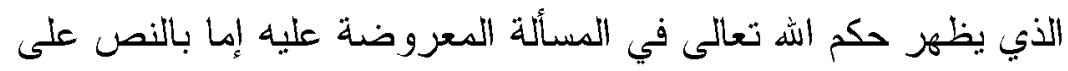

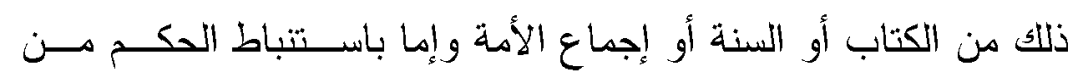
مظانه من الأدلة. r. هناك علاقة جادعة بين كل من الفتوى و القضاء، واجتماع كل هن فتوى

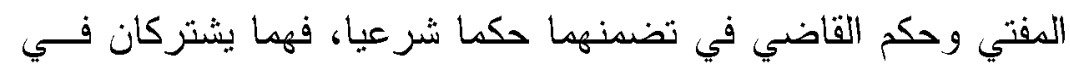

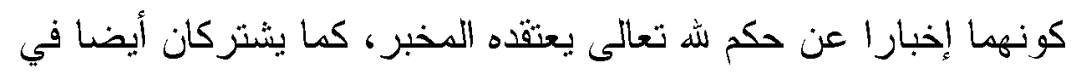

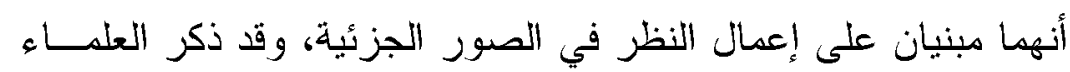

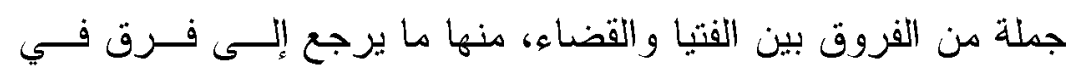

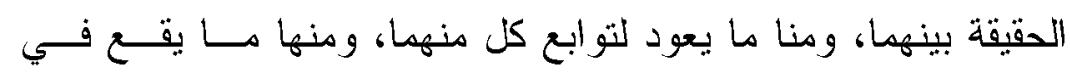

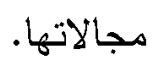

ع. اشترط الأصوليون شروطا في المفتي لا بد دن تو افرها كي تقبل فتــواه

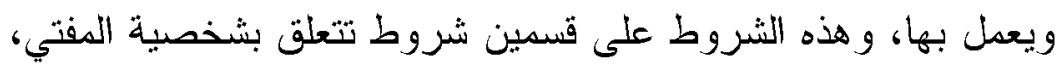

$$
\text { وشروط تتعلق بالإمكانيات العلمية للمفني. ونهي. }
$$

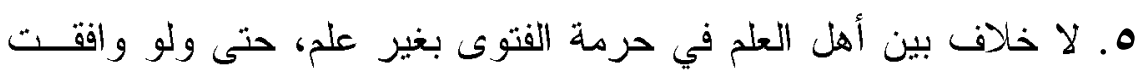

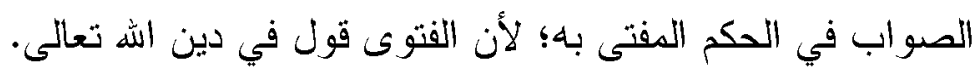

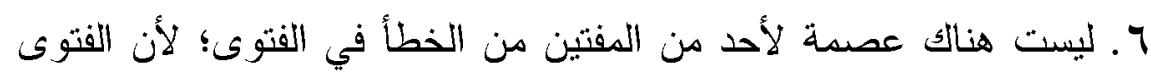

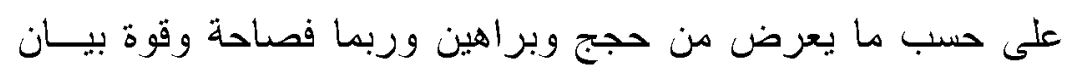

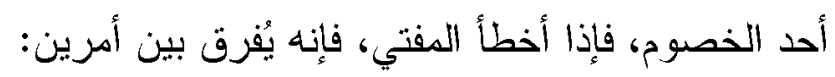


إن كان خطؤ لعدم أهلينه، أو كان أهلا لكنه لم يبذل جهده بل تعجل،

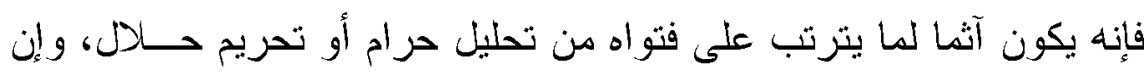

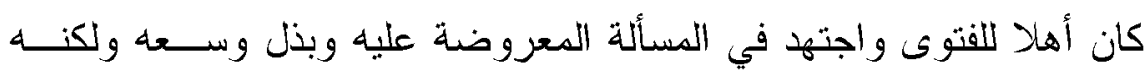
أخطأ الحكم الصحيح فلا إثم عليه، بل له أجر اجتهاده.

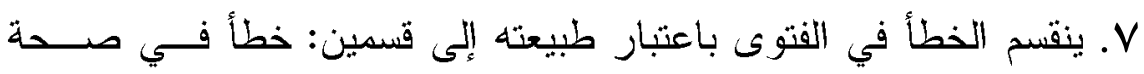
إدر اكه للحكم، وخطأ في تحقيق هناط الحكم.

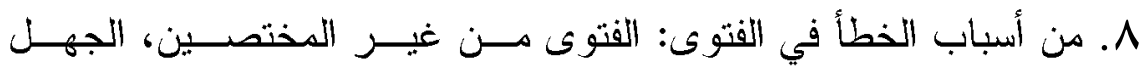

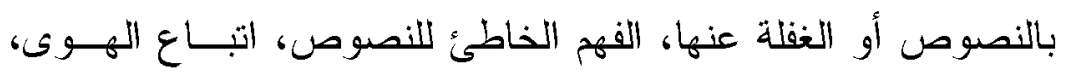

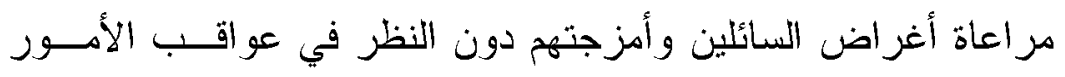

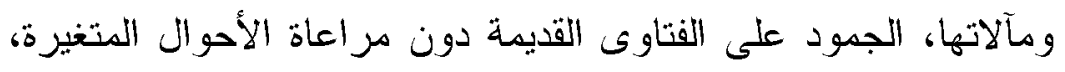
الجهل بمقاصد الثريعة، التسر ع و عدم الاحتراز و الحيطة في الفتوى.

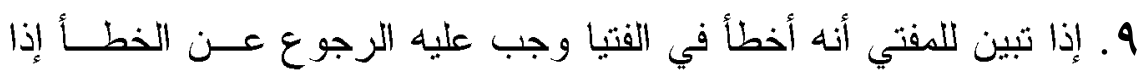

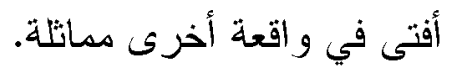

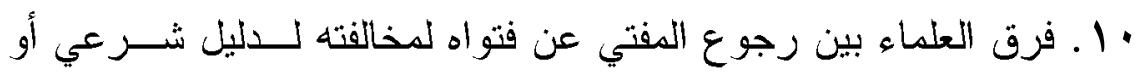

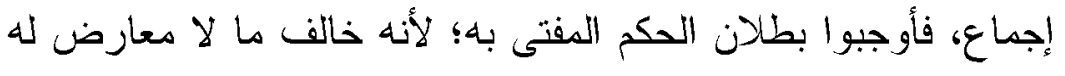

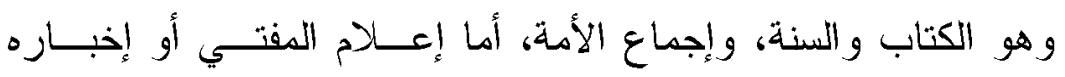

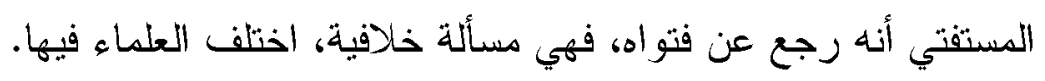

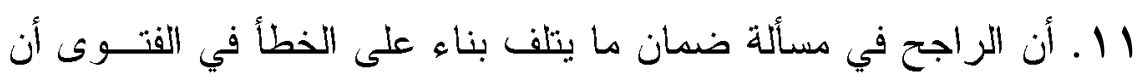

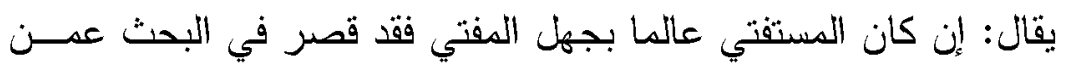

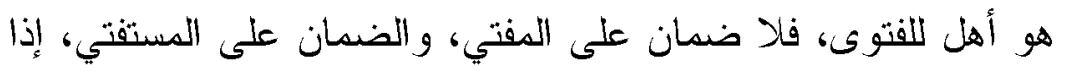

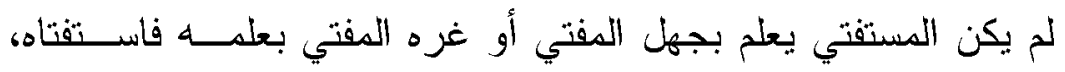

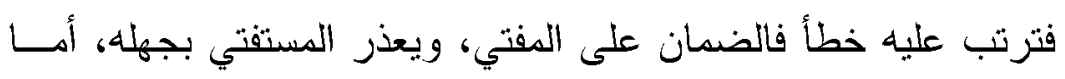

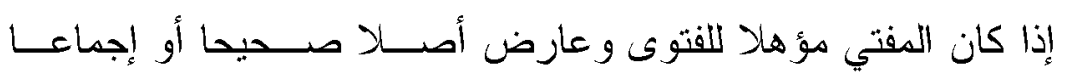

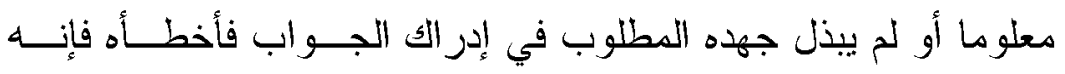
يضمن ؛ ولا يعذره الثار ع، بل يترتب على خطئه إثما. 
مجلة كلية الدراسات الإسلامية والعربية للبنات بدمنهور العدد الخامس الجزء التاسع •r+rم

$$
\text { كما أني أوصي: }
$$

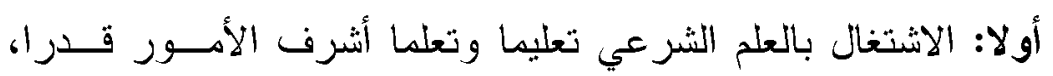

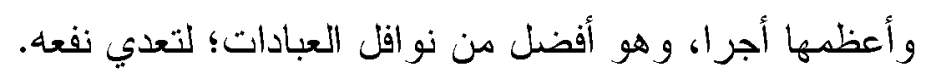

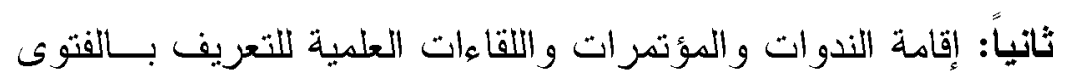
وأهميتها، و المفتي وشروطه و آدابه، وحاجة الناس إليهها.

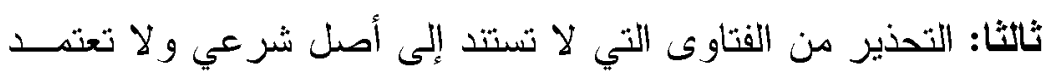

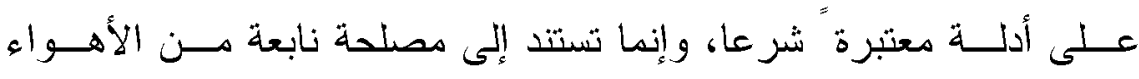

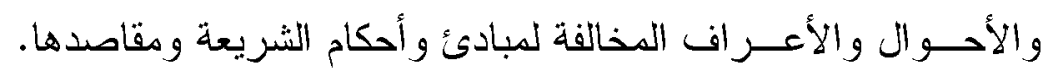

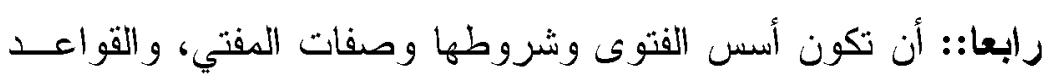

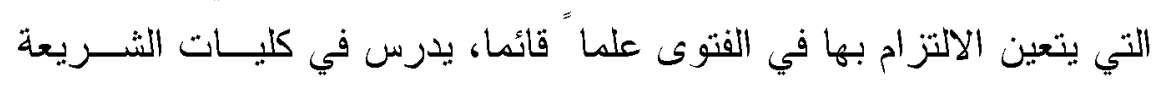
والمعاهد العليا.

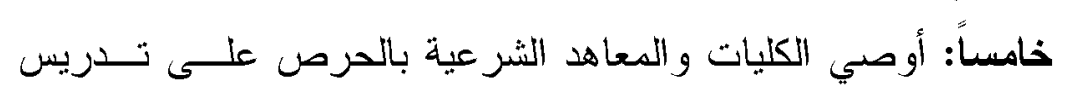

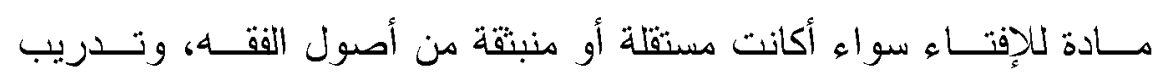

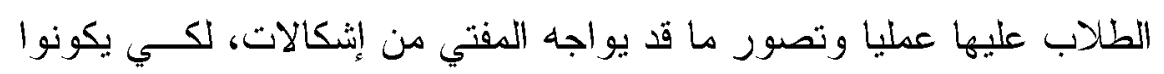

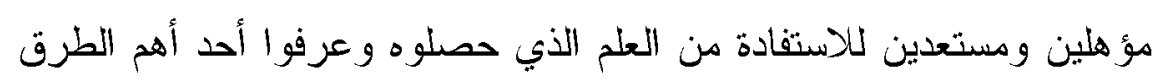
في إيصاله للناس.

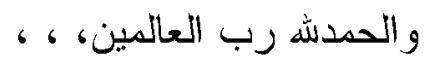




\section{مصادر البحث}

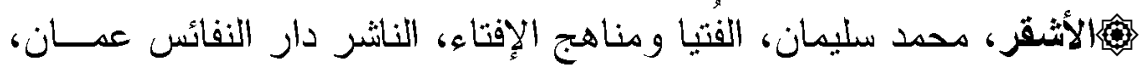

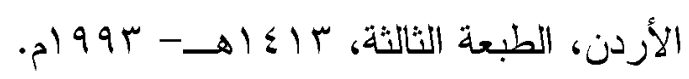

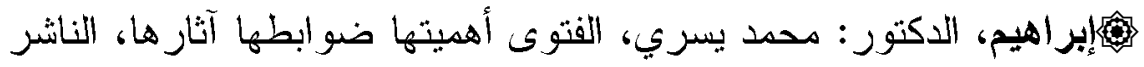

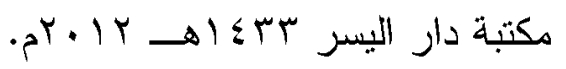

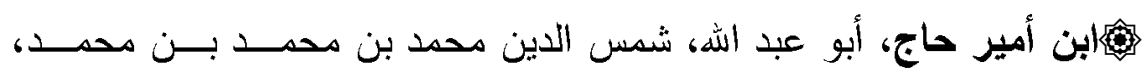

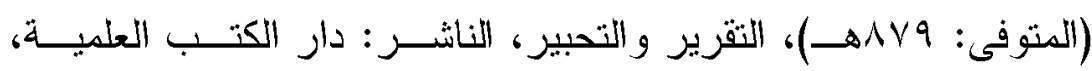

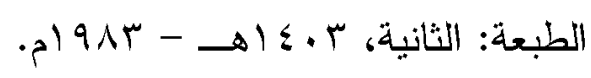

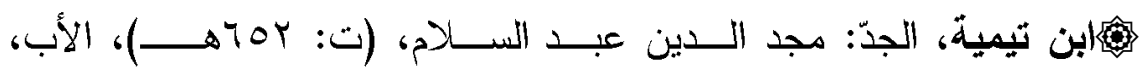

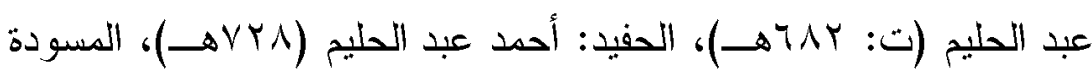
في أصول الفقه، تحقيق: دحمد دحيي الدين عبد الحميـد، الناثـــر : دار

$$
\text { الكتاب العربي. }
$$

جهابن تيمية، تقي الدين أبو العباس أحمد بن عبد الحليم بن عبد السلام بــن

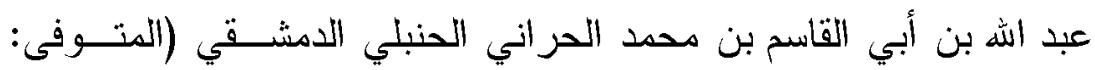

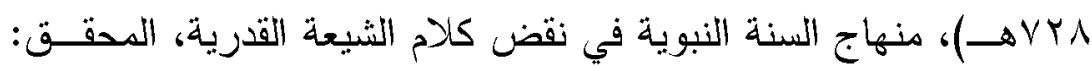

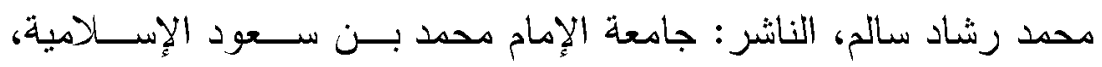

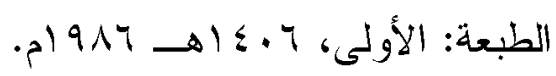

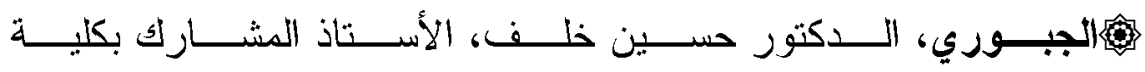
الثريعة والدراسات الإسلامية بجامعة أم القرى، عوارض الأهلية عـن الأن

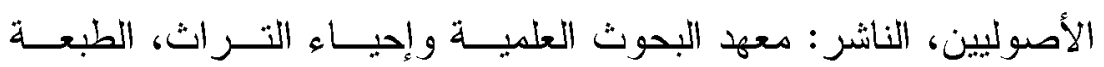

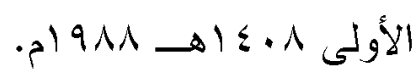

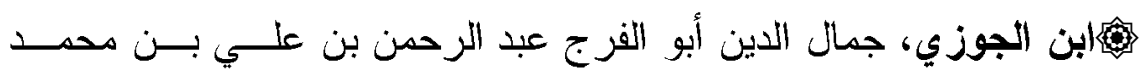

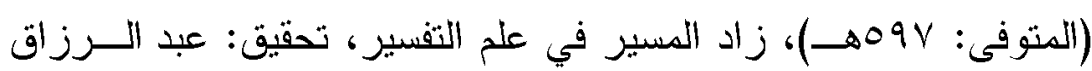

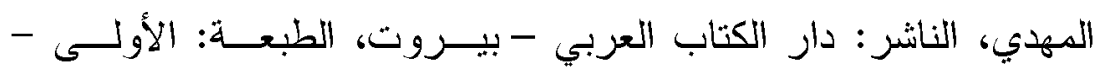


مجلة كلية الدراسات الإسلامية والعربية للبنات بدمنهور العدد الخامس الجزء التاسع •r+rم

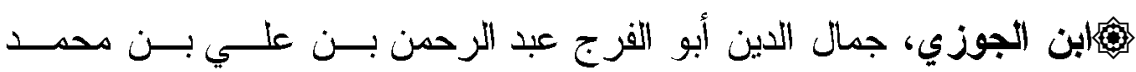

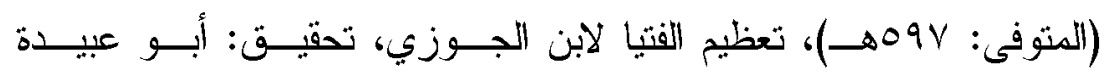

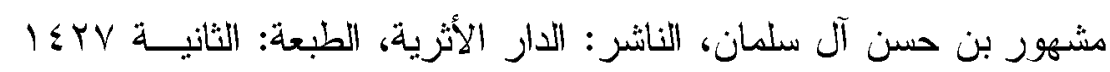

$$
\text { . }
$$

هوبن حزم، أبو محمد علي بن أحمد بن سعيد الأندلسي القرطبي الظلهري

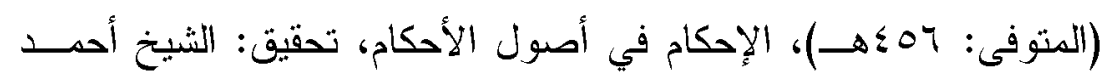
محمد شاكر، الناشر: دار الآفاق الجديدة، بيزوت.

قفابن حبتة، أبو يوسف يعقوب بن إبر اهيم بن حبيب بـن ســـد الأتصــاري

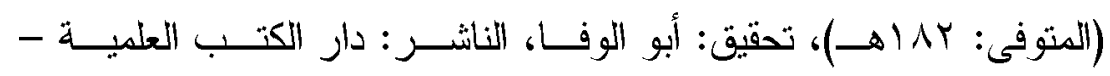

بيروت.

هُبرابن حمدان، أبو عبد الله أحمد بن حمدان بن شبيب بن حمدان النميـري الحرّاني الحنبلي، (المتوفى: 90 7هــ)، صفة الفتوى و المفتي و المستفتي، تحقيق: محمد ناصر الاين الألباني، الناشر: المكتب الإسلامي -بيروت،

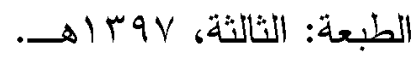

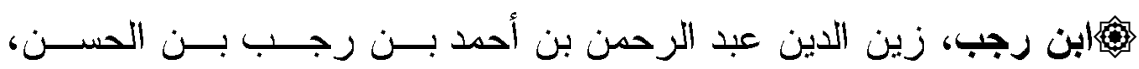

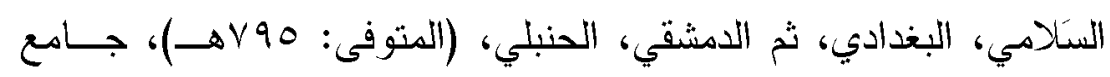
العلوم و الحكم في شرح خمسين حديثا هن جو اهع الكلم، تحقيق: شــعيب

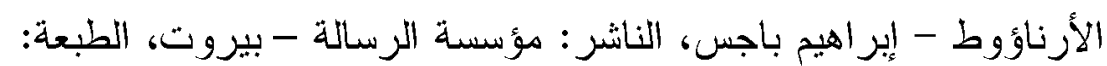

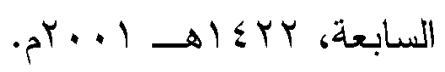

قوفابن سعد، أبو عبد الله محمد بن منيع، البصري، البغــدادي، (المتــوفى: • rrهــ) الطبقات الكبرى، تحقيق: دحمد عبد القادر عطا، الناشر: دار

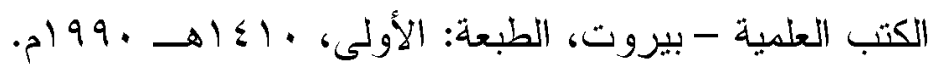


هُمابن الصلاح، الإمام الحافظ المحدث أبي عمرو عثمان بن عبد الــرحمن،

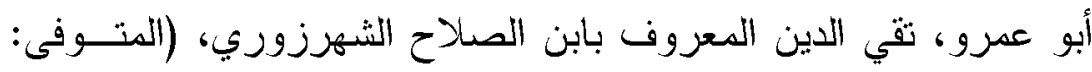

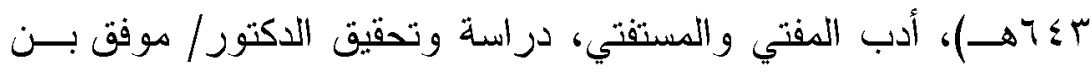

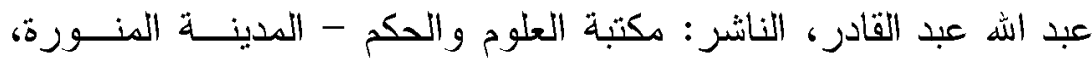

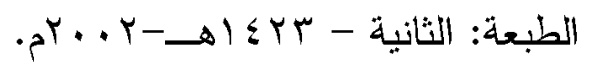

جفالطيار، الدكتور عبد الله بن محمد بن أحمد، أستاذ الدراسات العليا بكليــة

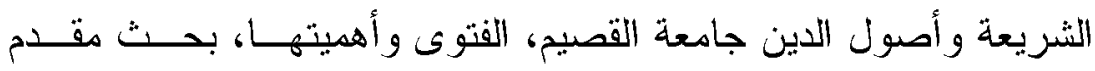

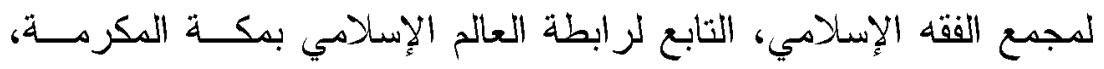
بحث منشور على الإنترنت.

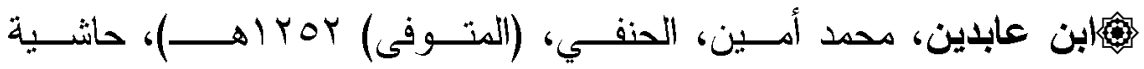

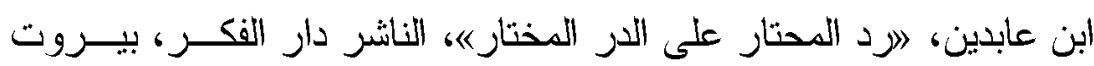

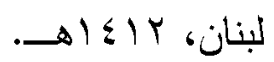

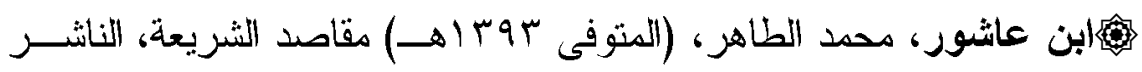

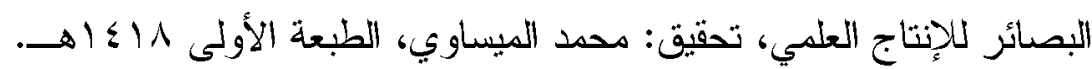

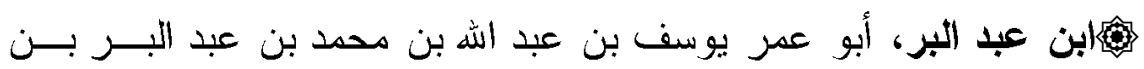

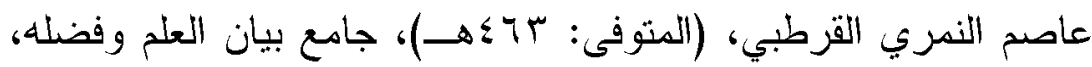

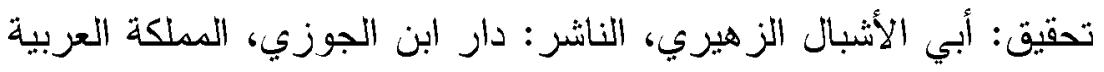

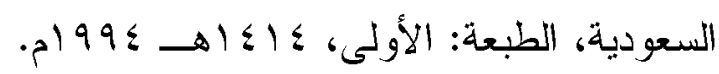

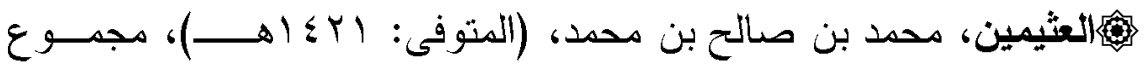

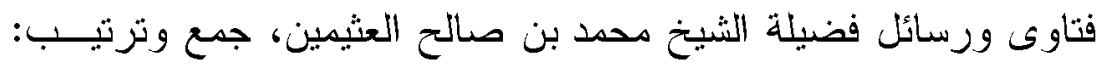
فهد بن ناصر بن إير اهيم السليمان، الناشر: دار الوطن - دار الثريا.

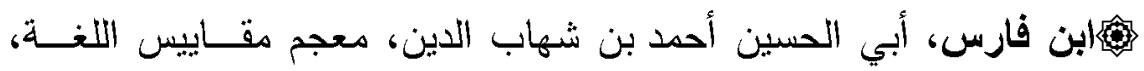

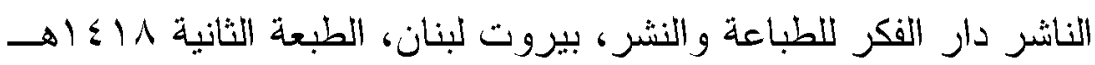


مجلة كلية الدراسات الإسلامية والعربية للبنات بدمنهور العدد الخامس الجزء التاسع •r+rم

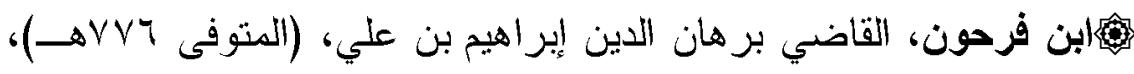

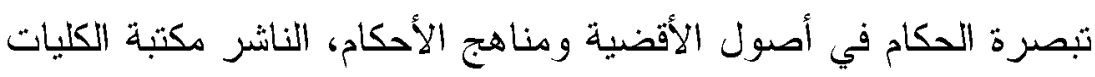

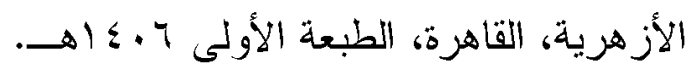

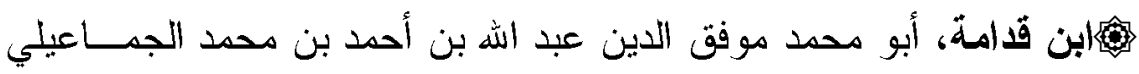

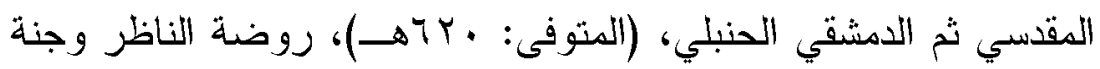

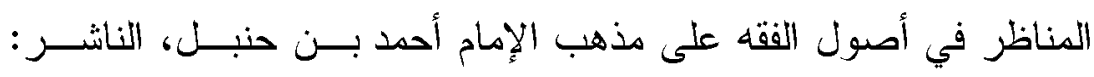

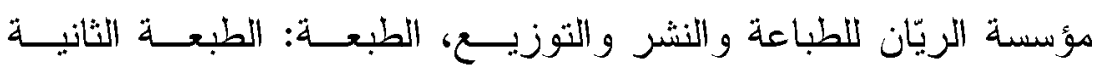
. . . r-

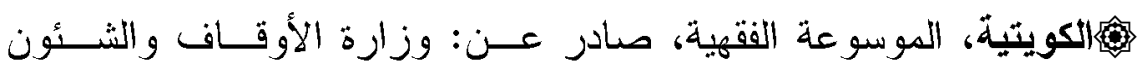

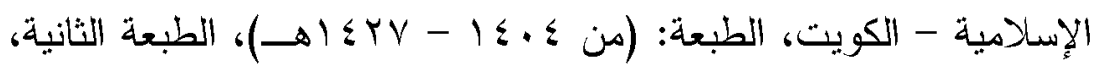

$$
\text { دار السلاسل - الكويت. }
$$

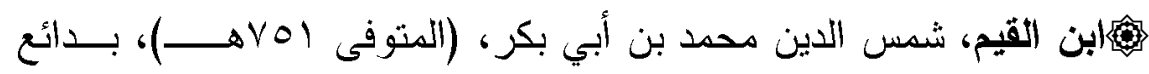

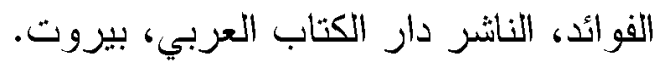

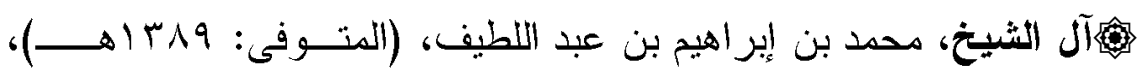

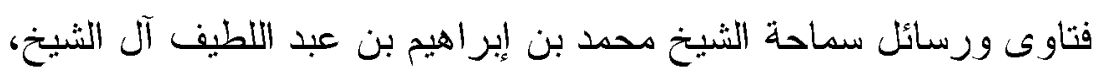

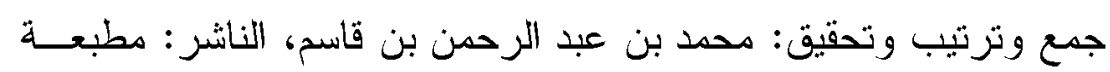

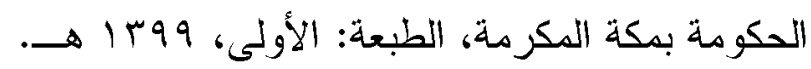

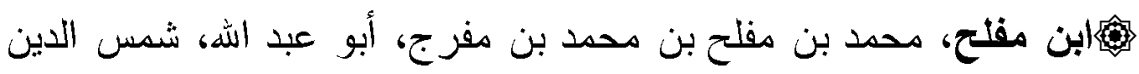

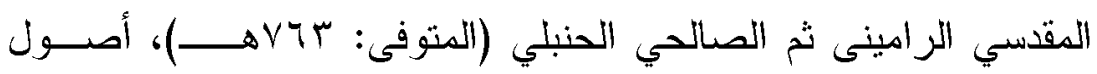
الفقه، حققه و علق عليه وقدم له: الدكتور فهذ بن محمد السَّدَحَان، الناشر :

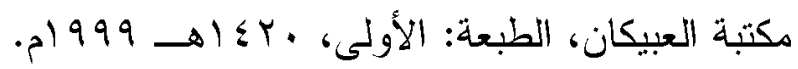

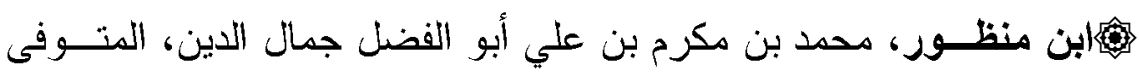

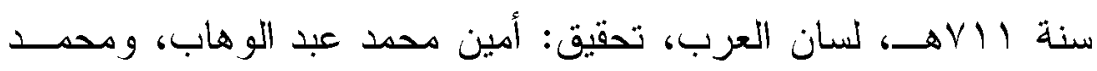

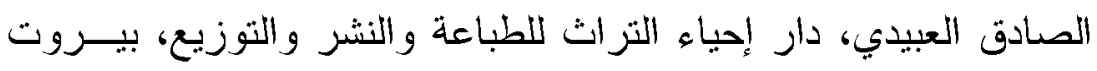

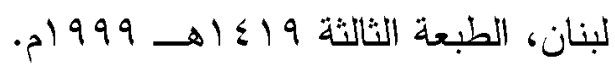




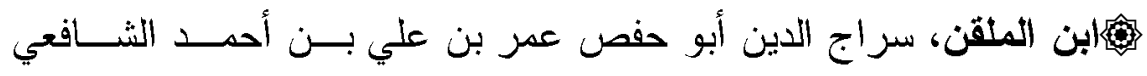

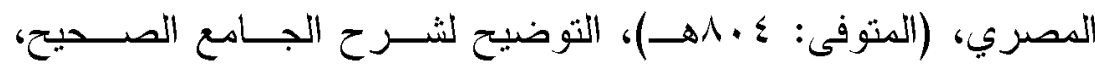

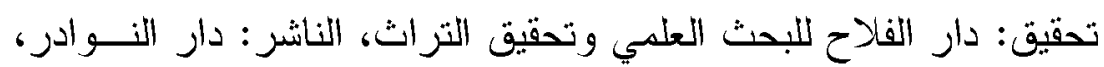

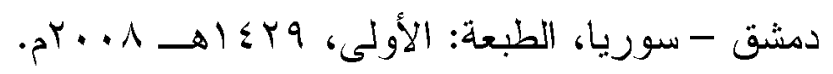

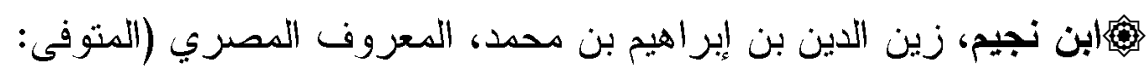

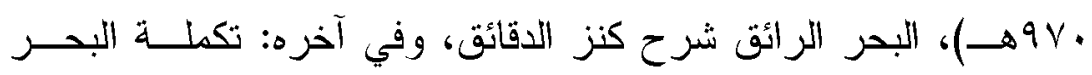

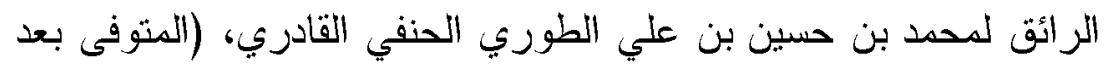

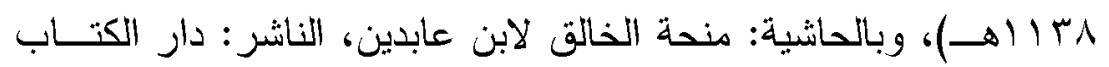
الإسلاني.

\$جه|أباجي، أبو الوليد، سليمان بن خلف، المنتقى شرح الموطأ، الناشــر دار الكتاب الإسلامي، الطبعة الثانية.

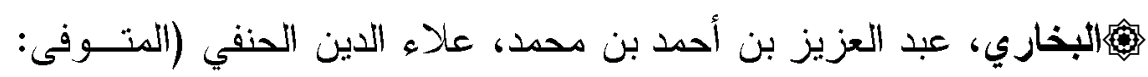

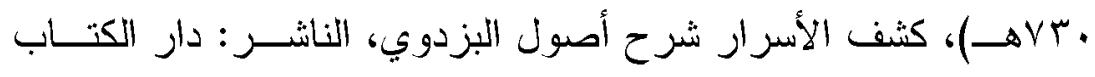

$$
\text { الإسلامي. }
$$

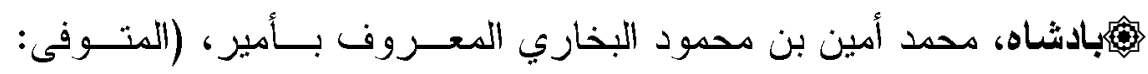


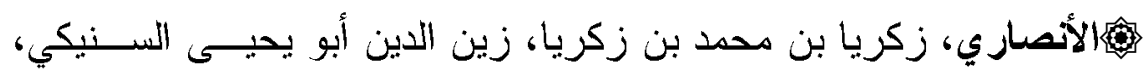

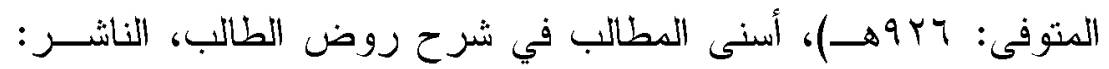

$$
\text { دار الكتاب الإسلاهي. }
$$

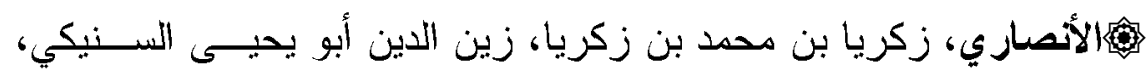

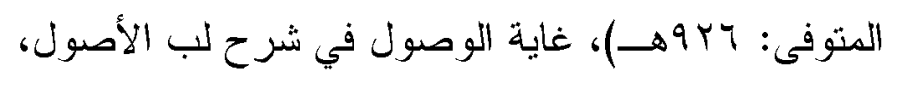

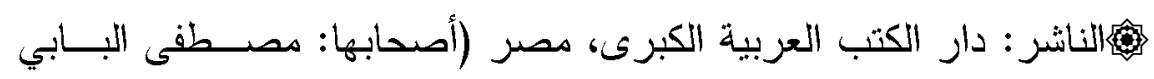
الحلبي وأخويه). 
مجلة كلية الدراسات الإسلامية والعربية للبنات بدمنهور العدد الخامس الجزء التاسع • +r م

هن|البهوني، دنصور بن يونس بن صلاح الدين بن حسن بن إدريس الحنبلي

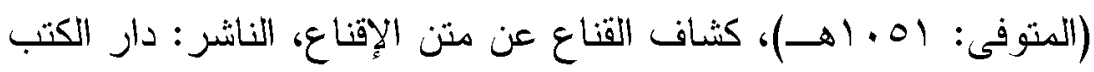
العلمي.

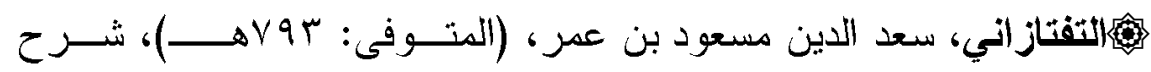

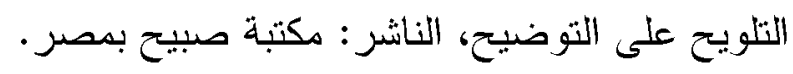

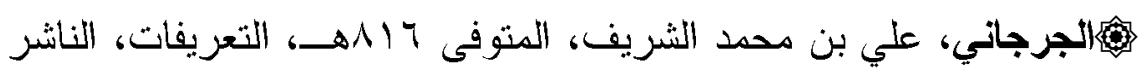

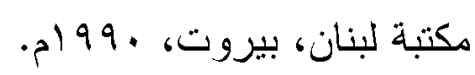

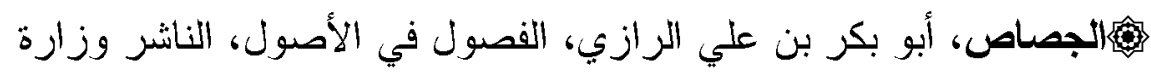

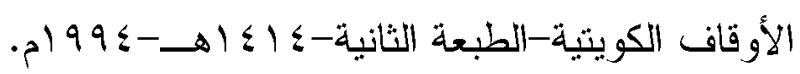

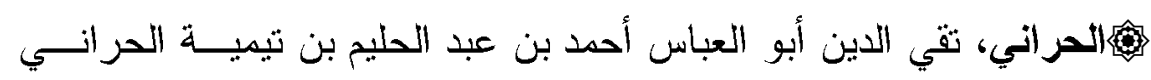

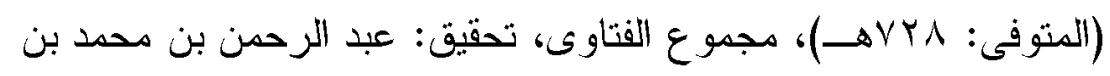

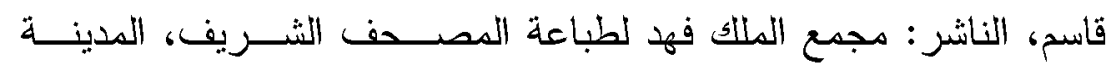

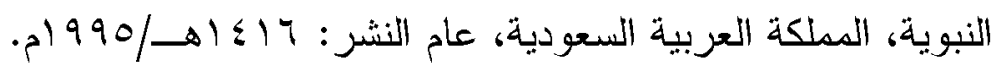

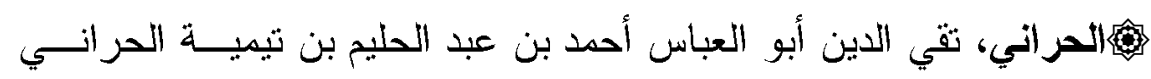

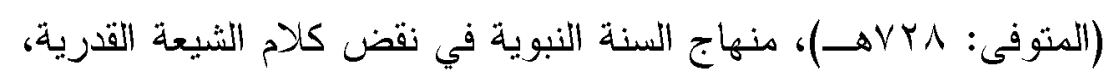
(المتوفى: N

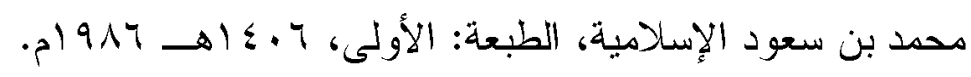

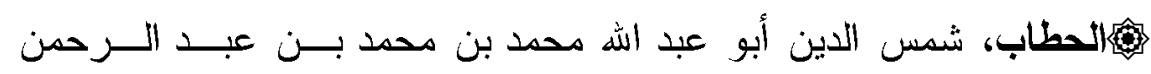

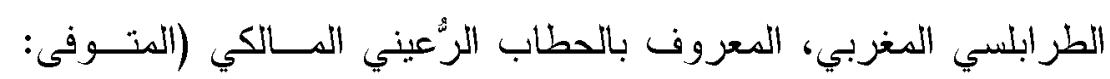

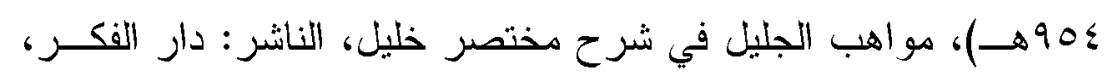

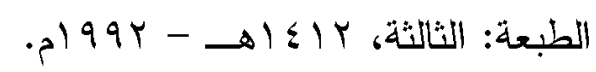

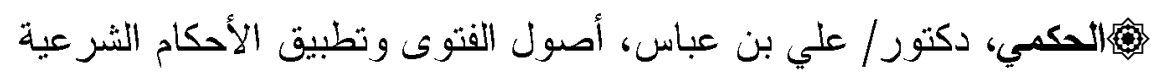

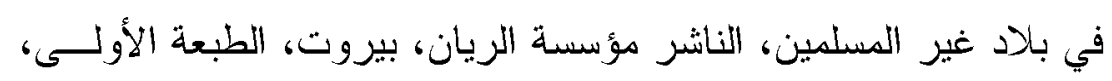
. $1999 \rightarrow 1 \leq r$. 
هفرالحموي، أحدد بن محمد مكي، أبو العباس، شهاب الدين الحســيني الحمـوي

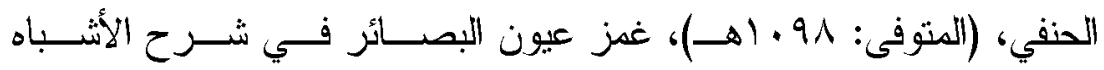

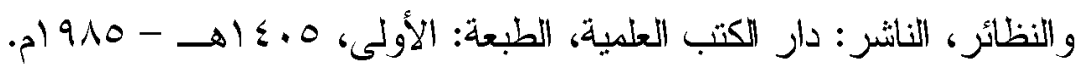

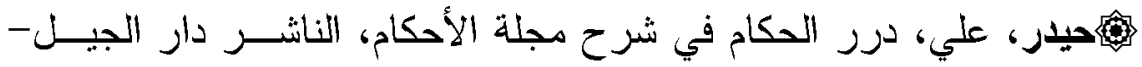

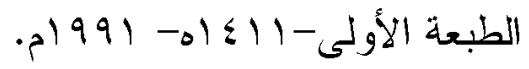

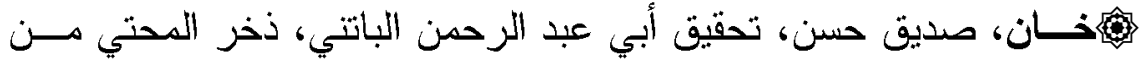

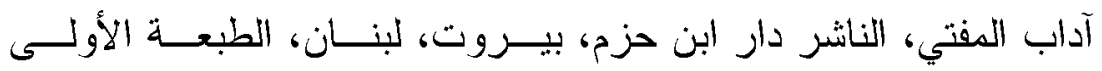

$$
\text { . . . }
$$

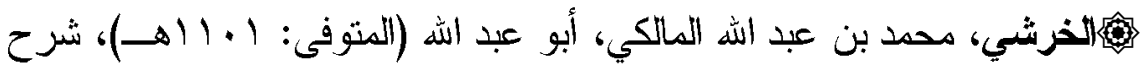
مختصر خليل للخرشي، الناشر: دار الفكر للطباعة -بيروت.

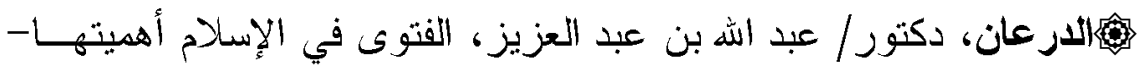

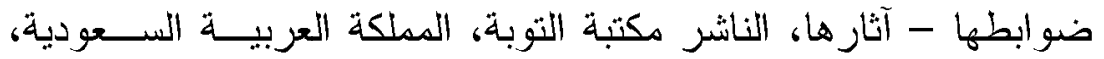

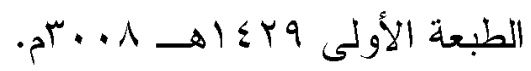

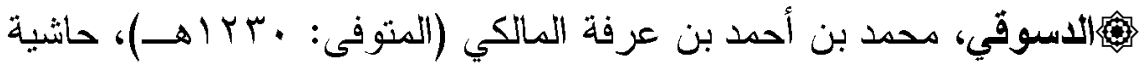
الاسوقي على الثرح الكبير، الناشر : دار الفكر .

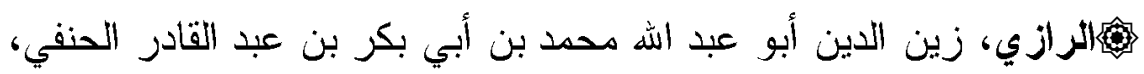

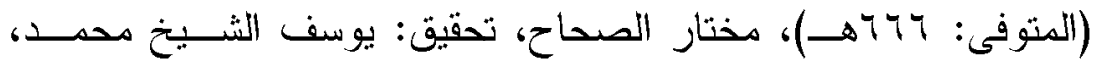
الناشر: المكتبة العصرية - الدار النموذجية، بيروت - صيدا، الطبعـة:

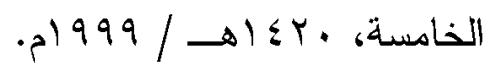

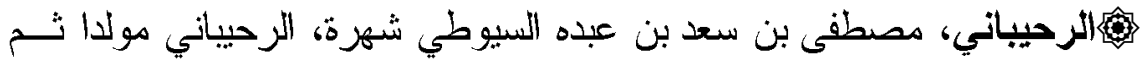

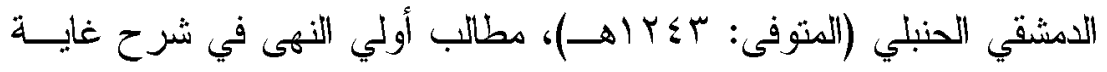

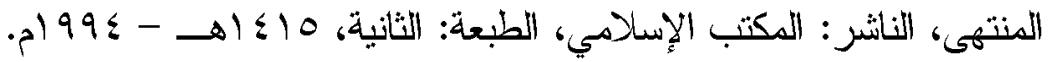

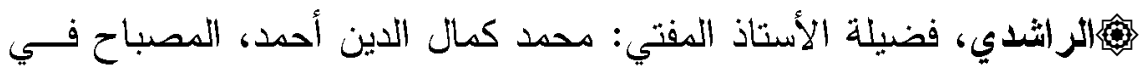

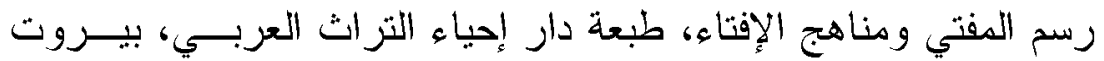

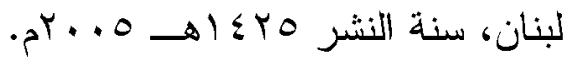


مجلة كلية الدراسات الإسلامية والعربية للبنات بدمنهور العدد الخامس الجزء التاسع •r+rم

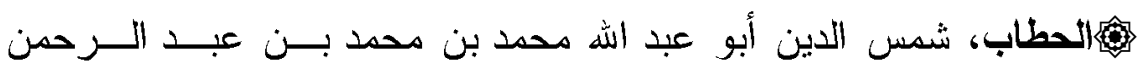

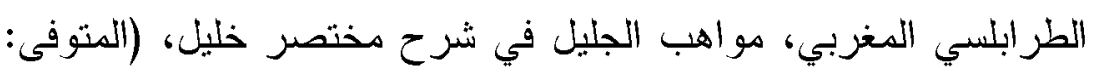

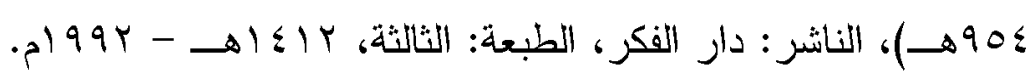

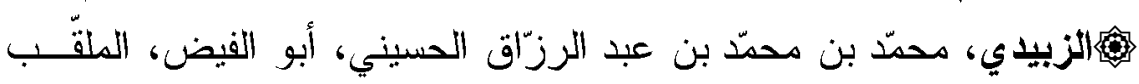

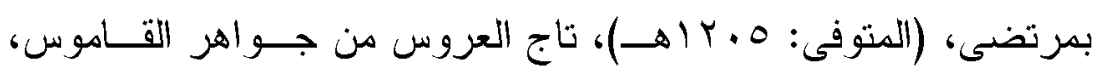

مجمو عة من المحققين.

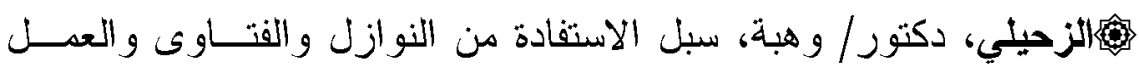

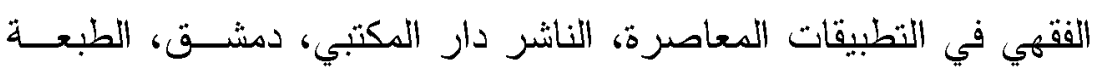

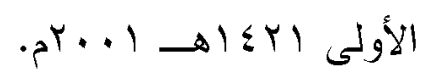

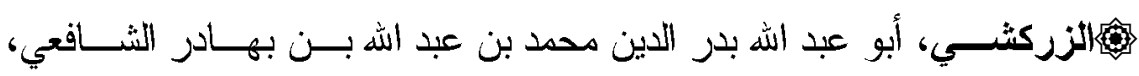

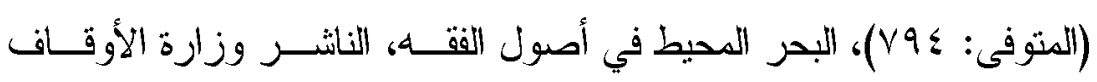

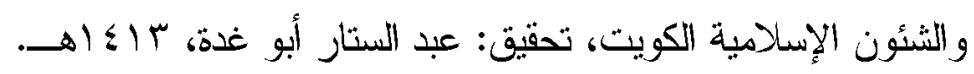

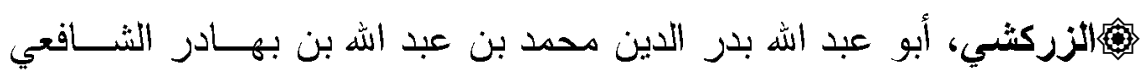

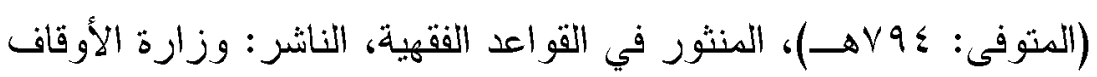

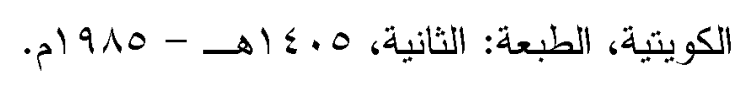

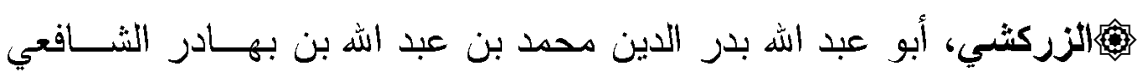

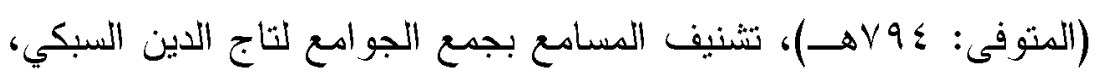

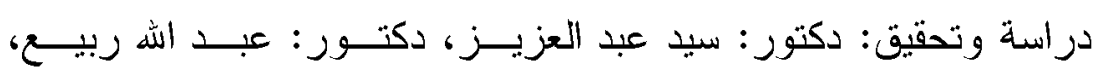

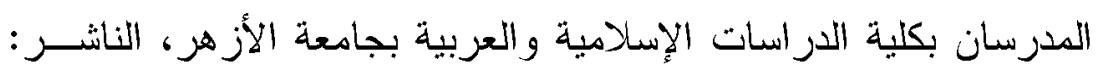

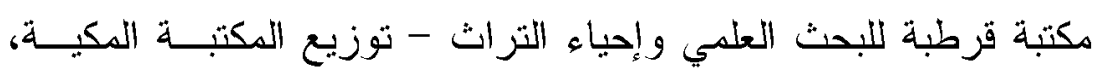

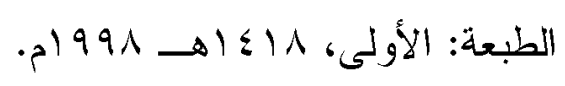

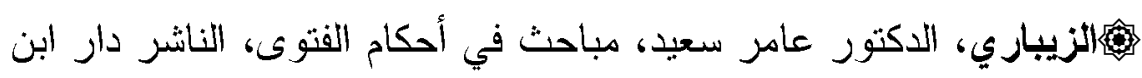

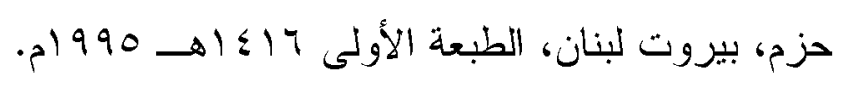




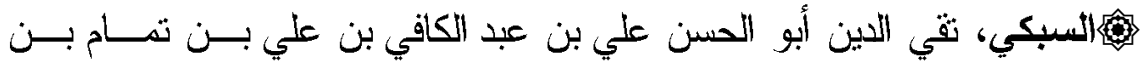

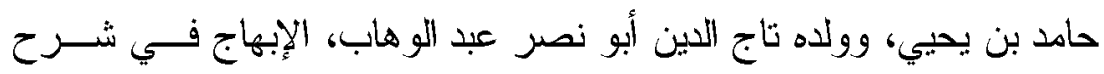

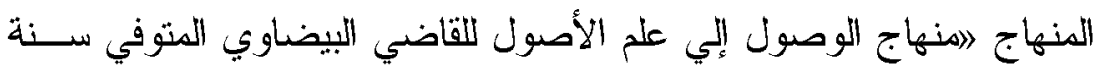

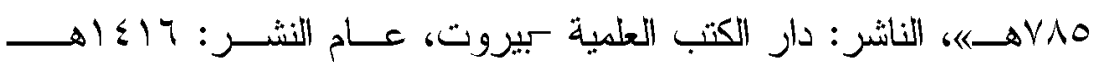
.1990 هف|السمرقندي، أبو الليث، عيون الدسائل والنوازل، تحقيق: صلاح الــدين

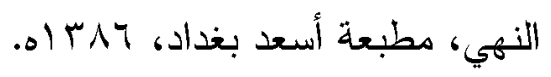

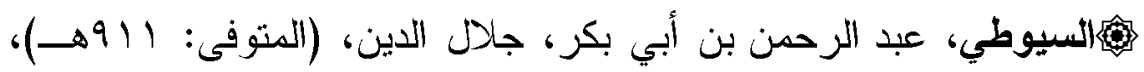

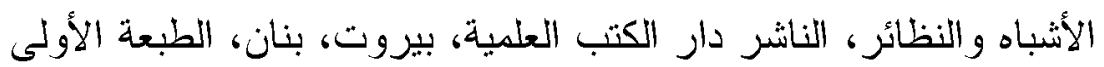

$$
\text { . } \rightarrow 1 \leqslant r \text {. }
$$

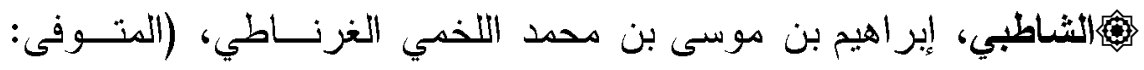
.

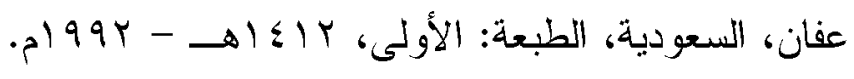

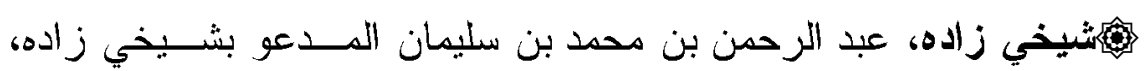

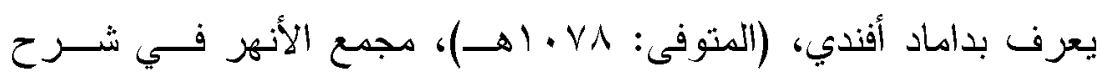

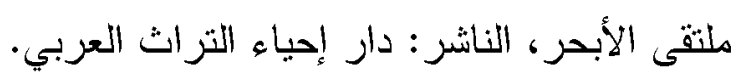

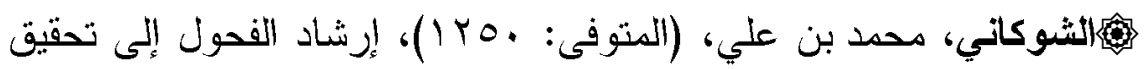

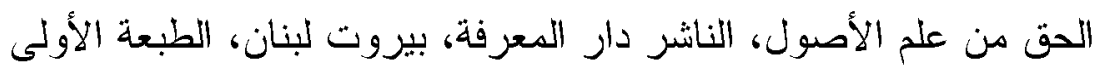

$$
\text { . } 19 \vee 9 \rightarrow 1199
$$

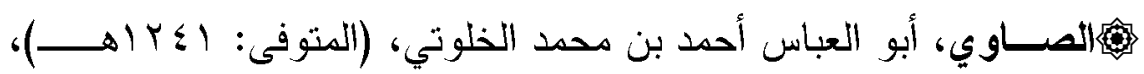

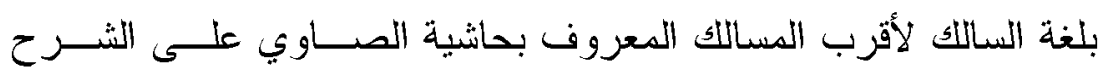

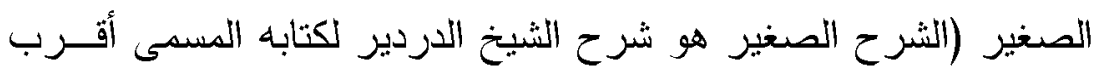

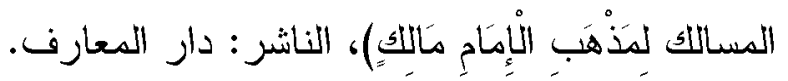


مجلة كلية الدراسات الإسلامية والعربية للبنات بدمنهور العدد الخامس الجزء التاسع •r+rم

هُ|الصرصري، سليمان بن عبد القوي بن الكريم الطوفي، أبو الربيع، نجم الــدين

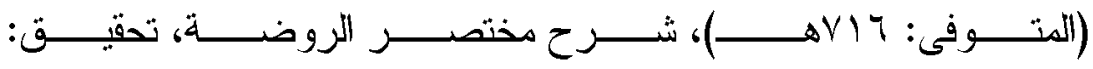

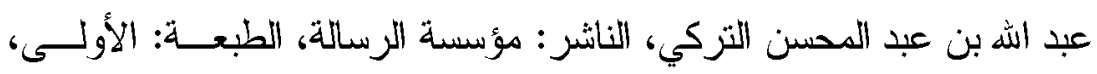
. $19 \wedge \vee \rightarrow 1 \leq . \vee$

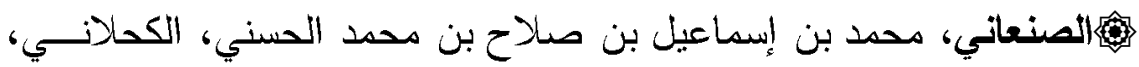

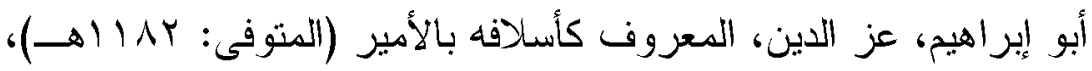

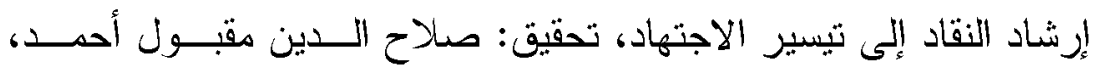

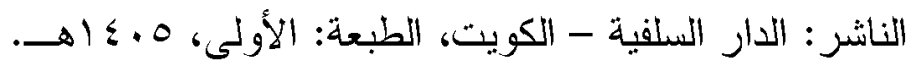

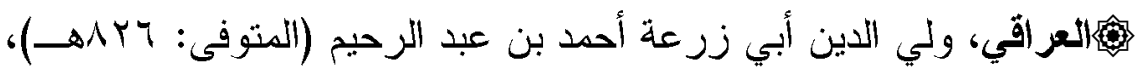
الغيث الهامع شرح جمع الجوامع، تحقيق: محدد تامر حجازي، الناشر :

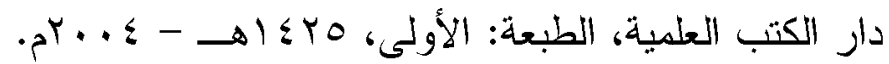

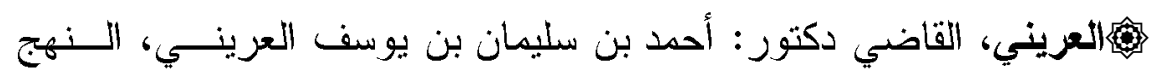

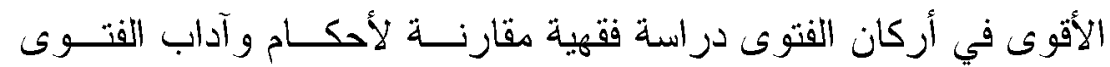

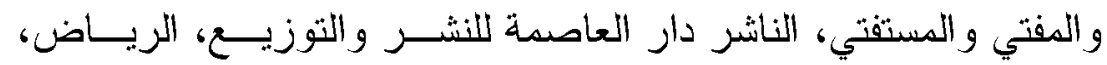

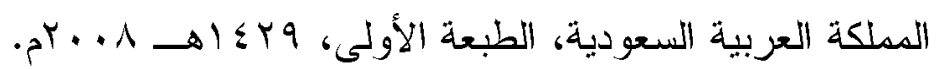

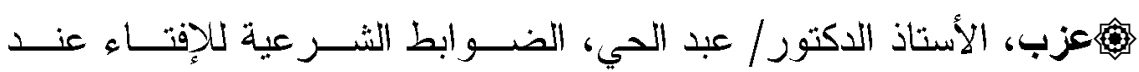

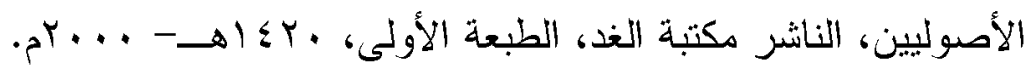

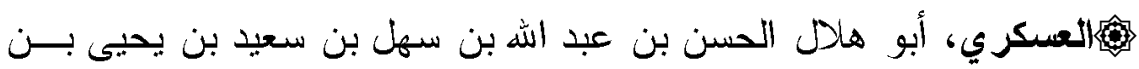

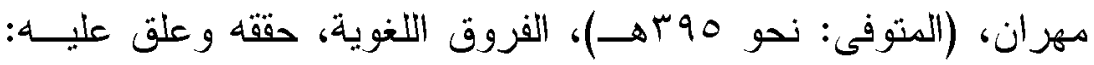
هحمد إبر اهيم سليم، الناشر : دار العلم والثقافة للنشر والتوزيع، القاهرة مصر

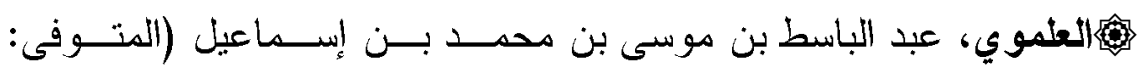
1 19هـ)، العقد التليد في اختصار الدر النضيد = المعيد في أدب المفيد والمستفيد، تحقيق: الدكتور/ مروان العطية، الناشر: مكتبة التقافة الدينية،

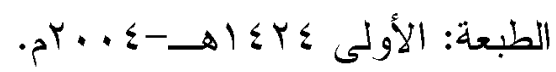




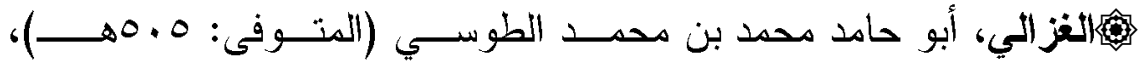

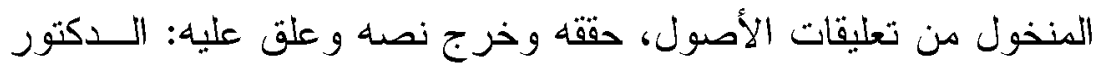
محمد حسن هيتو، النانشر: دار الفكر المعاصر - بيروت لبنانه لبنان، دار الفكر

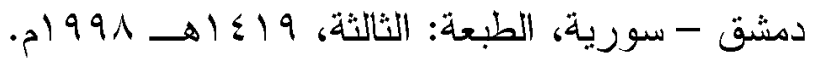

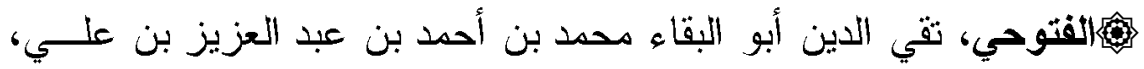

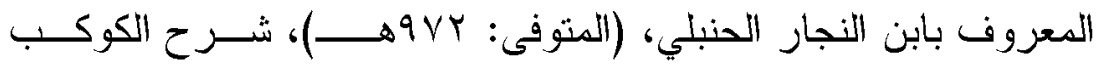

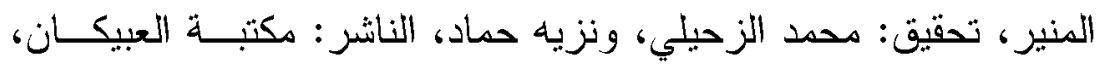

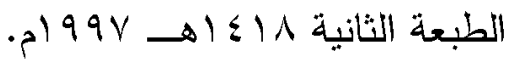

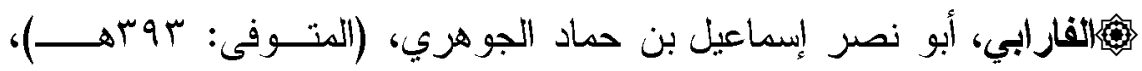

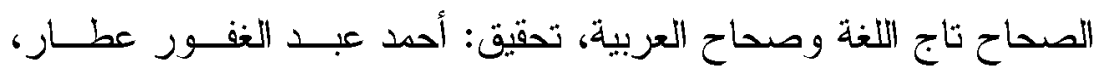

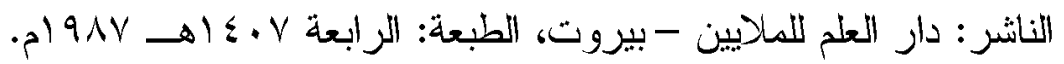

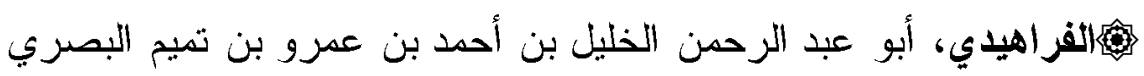

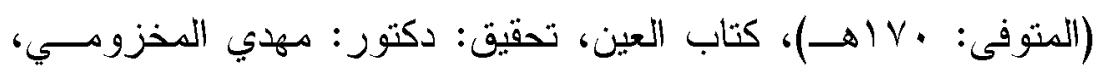

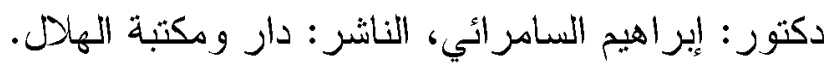

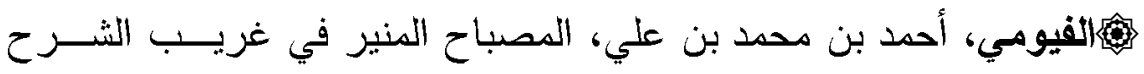
الكبير، الناشر دار الفكر .

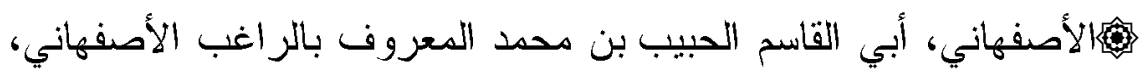

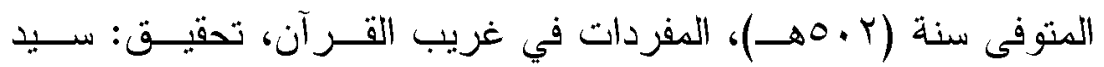

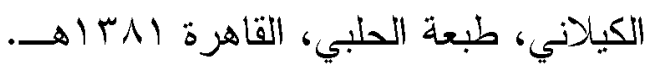

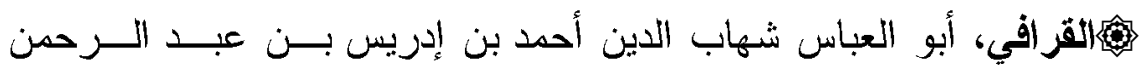

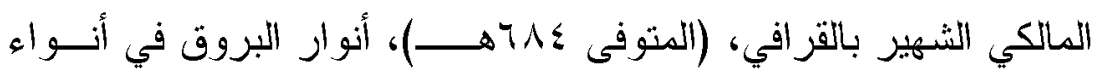

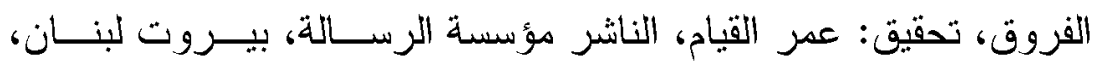

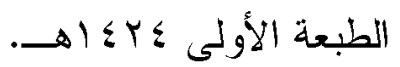

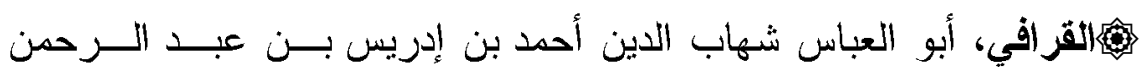

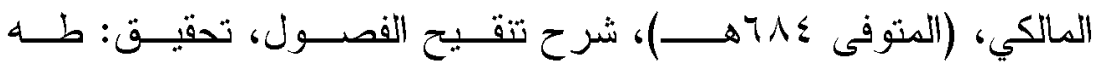

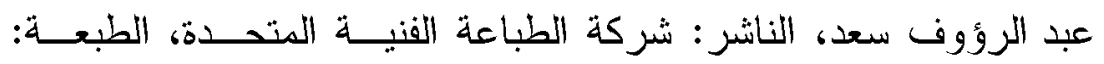

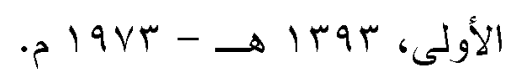


مجلة كلية الدراسات الإسلامية والعربية للبنات بدمنهور العدد الخامس الجزء التاسع •r+rم

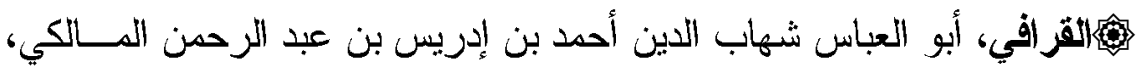

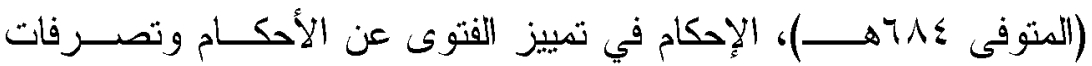

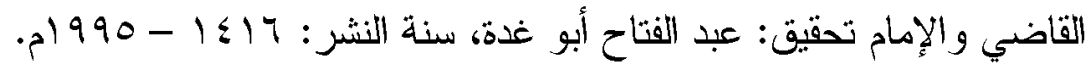

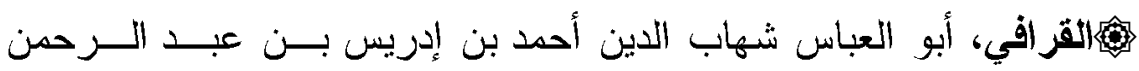

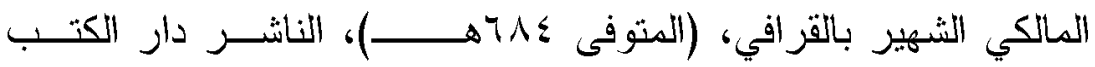

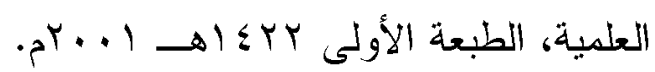

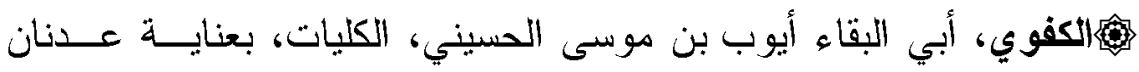

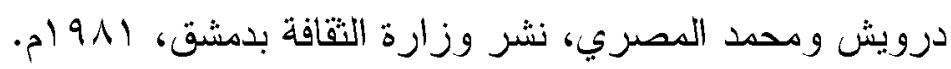

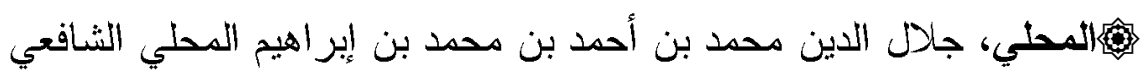

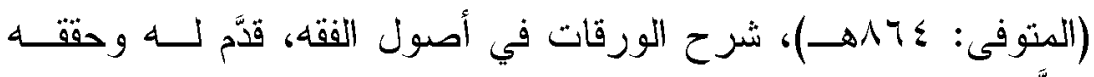

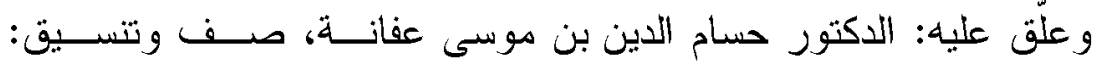

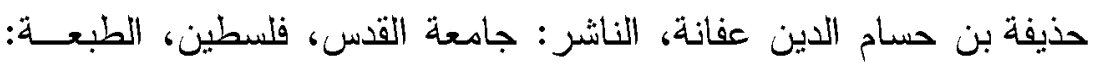

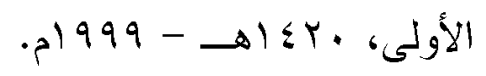

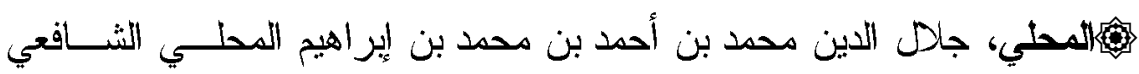

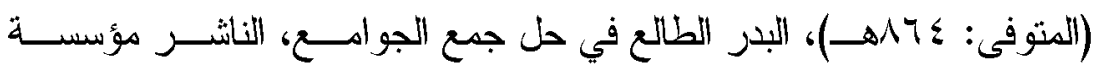

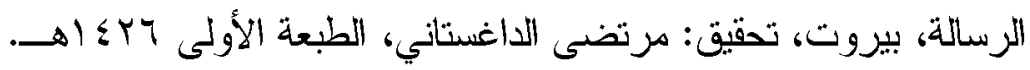

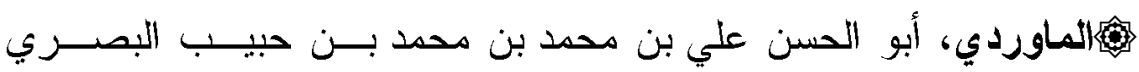

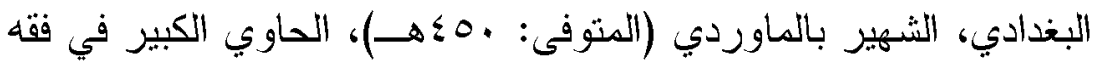

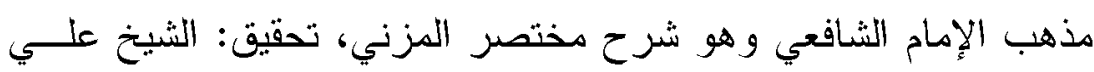

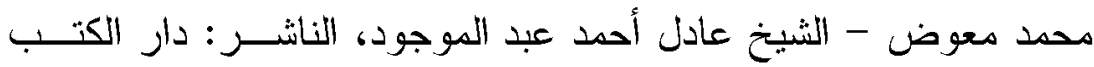

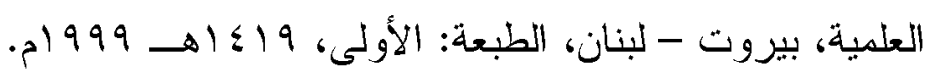

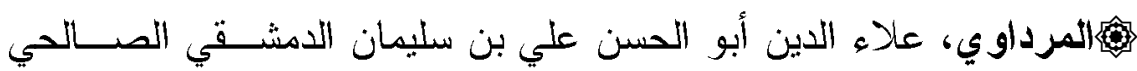

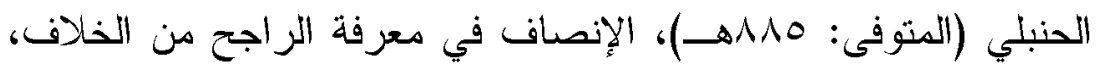
الناشر : دار إحياء التراث العربئ 


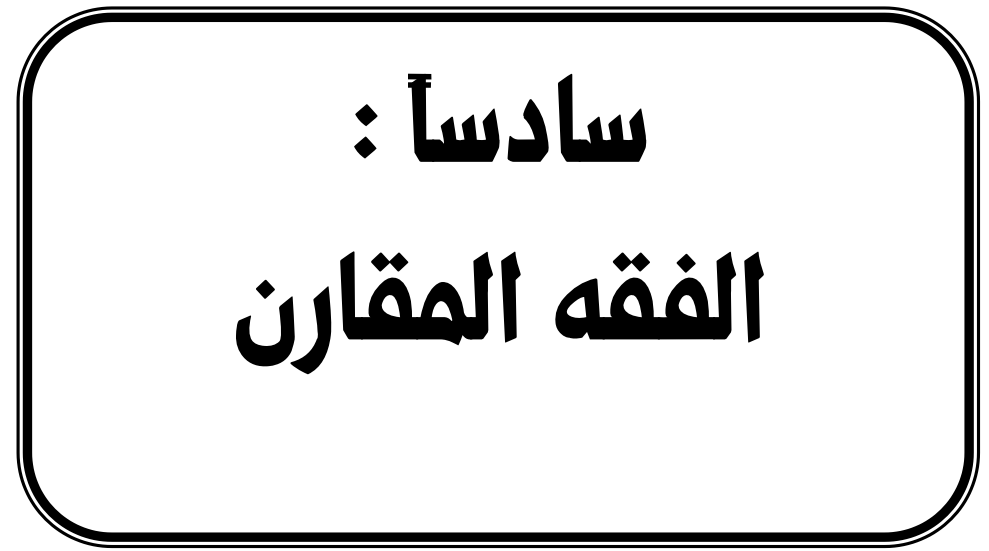


